Portland State University

PDXScholar

8-25-2015

\title{
Synthesis and Structure-Activity Relationships of Tambjamines and B-Ring Functionalized Prodiginines as Potent Antimalarials
}

\author{
Papireddy Kancharla \\ Portland State University \\ Jane Xu Kelly \\ Veterans Affairs Medical Center \\ Kevin A. Reynolds \\ Portland State University
}

Follow this and additional works at: https://pdxscholar.library.pdx.edu/chem_fac

Part of the Medicinal-Pharmaceutical Chemistry Commons

Let us know how access to this document benefits you.

\section{Citation Details}

Kancharla, P., Kelly, J. X., \& Reynolds, K. A. (2015). Synthesis and Structure-Activity Relationships of Tambjamines and B-Ring Functionalized Prodiginines as Potent Antimalarials. Journal of Medicinal Chemistry, 58(18), 7286-7309.

This Article is brought to you for free and open access. It has been accepted for inclusion in Chemistry Faculty Publications and Presentations by an authorized administrator of PDXScholar. Please contact us if we can make this document more accessible: pdxscholar@pdx.edu. 


\title{
Journal of \\ Medicinal \\ Chemistry
}

\section{Synthesis and Structure-Activity Relationships of Tambjamines and B-Ring Functionalized Prodiginines as Potent Antimalarials}

\author{
Papireddy Kancharla, ${ }^{\dagger}$ Jane Xu Kelly, ${ }^{\dagger,}$ and Kevin A. Reynolds*, \\ ${ }^{\dagger}$ Department of Chemistry, Portland State University, Portland, Oregon 97201, United States \\ ${ }^{\ddagger}$ Veterans Affairs Medical Center, Portland, Oregon 97239, United States
}

Supporting Information

ABSTRACT: Synthesis and antimalarial activity of 94 novel bipyrrole tambjamines (TAs) and a library of B-ring functionalized tripyrrole prodiginines (PGs) against a panel of Plasmodium falciparum strains are described. The activity and structure-activity relationships demonstrate that the ring-C of PGs can be replaced by an alkylamine, providing for TAs with retained/enhanced potency. Furthermore, ring-B of PGs/TAs can be substituted with short alkyl substitutions at either 4-position (replacement of $\mathrm{OMe}$ ) or 3- and 4-positions without impacting potency. Eight representative TAs and two PGs have been evaluated for antimalarial activity against multidrug-resistant $P$. yoelii in mice in the dose range of $5-100 \mathrm{mg} / \mathrm{kg} \times 4$ days by oral administration. The KAR425 TA offered greater efficacy than previously observed for any PG, providing $100 \%$ protection to malaria-infected mice until day 28 at doses of 25 and $50 \mathrm{mg} / \mathrm{kg} \times$ 4 days, and was also curative in this model in a single oral dose $(80 \mathrm{mg} / \mathrm{kg})$. This study

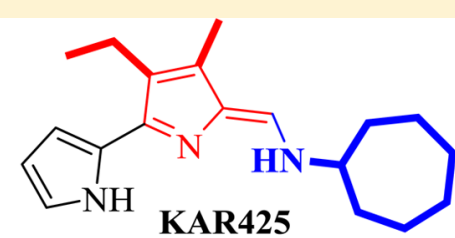

$\mathrm{IC}_{50}(\mathrm{nM})=62(\mathrm{D} 6), 55(\mathrm{Dd} 2), 60(7 \mathrm{G} 8)$ Cytotoxicity $\left(\mathbf{I C}_{\mathbf{5 0}}\right)=19200 \mathrm{nM}(\mathrm{HepG} 2)$ $\mathbf{E D}_{\mathbf{5 0}}<2.5 \mathrm{mg} / \mathrm{kg} / \mathrm{day} ; \mathbf{c L o g P}=2.7$ NRD $=25$ and $50 \mathrm{mg} / \mathrm{kg} \times 4$ days by oral Curative in a single oral dose $(80 \mathrm{mg} / \mathrm{kg})$ presents the first account of antimalarial activity in tambjamines.

\section{INTRODUCTION}

Malaria is a global parasitic infectious disease caused by Plasmodium parasites, among which Plasmodium falciparum (Pf) is the most dangerous one, with the highest rates of complications and mortality. It has been estimated that 584000 people died from this disease in 2013, and the burden is heaviest in the African region, where an estimated $90 \%$ of all malaria deaths occur, and in children aged under 5 years, who account for $78 \%$ of all deaths. ${ }^{1}$ On the heels of the global spread of chloroquineresistant $P$. falciparum $\left(\mathrm{CQ}^{\mathrm{R}} P f\right)$, resistance has also quickly developed to a variety of quinoline analogues, to antifolates, to inhibitors of electron transport, and perhaps most ominously, now to artemisinin. ${ }^{2,3}$ Therefore, novel medicinal agents are urgently needed to overcome the emergence and spread of resistance.

Prodiginines (PGs, $\mathbf{1 a - c}$ ), tambjamines (TAs, 2a-b), and modified prodiginines (streptorubin B (3a), metacycloprodiginine ( $3 \mathbf{b})$, and marineosins (4 and 5$)$ ) belong to a family of pyrrolylpyrromethene (PPM) alkaloids (Figure 1) derived from bacterial and marine sources. ${ }^{4-7}$ These structurally distinctive natural products can be envisioned to arise via a bifurcated process from a common precursor, 4-methoxy-2,2'-bipyrrole-5carboxaldehyde (MBC; 6, Figure 1), and the corresponding alkylpyrrole and/or alkylamine. ${ }^{7-10}$ The natural and synthetic PPM products are undergoing intense scrutiny in the medicinal chemistry because of both their wide range of biological activities and modes of action (antimicrobial, ${ }^{11-14}$ immunosuppressive, ${ }^{15-22}$ antitumor, ${ }^{11,12,23}$ anticancer, ${ }^{6,24-30}$ antimalarial, ${ }^{7,31-38}$ transmembrane anion transport, ${ }^{28-30,39-45}$ and DNA intercalation $\left.{ }^{46,47}\right)$. Certain PGs and TAs have also been observed to bind duplex DNA and can cleave this biomolecule in the presence of $\mathrm{Cu}(\mathrm{II}){ }^{4,48}$ Some of these compounds have shown clinical potential, and in particular, PG analogue GX15070 has completed phase II clinical trials for the treatment of small cell lung cancer and is engaged in multiple clinical trials for the treatment of other cancer conditions. ${ }^{49,50}$

As a part of an ongoing interest in developing new antiparasitic agents, we reisolated the natural PGs 1a and 3a from Streptomyces coelicolor M511, and $\mathbf{3 b}$ from S. longisporusruber (Figure 1). ${ }^{51,52}$ These natural PGs exhibited great potency with very low $\mathrm{IC}_{50}$ values against $P$. falciparum strains, a potency only slightly more than chloroquine (CQ). ${ }^{37}$ The natural PG $\mathbf{3 b}$ provided an excellent in vivo efficacy against multidrug-resistant $P$. yoelii in mice by oral route, and it was curative in this model at $100 \mathrm{mg} \mathrm{kg}^{-1}$ day $^{-1}$, and three of four mice were cured. These data provided the first demonstration of oral effectiveness of PGs. ${ }^{37}$ Recently we also have isolated the modified prodiginines, marineosins (5), and their pathway intermediates 23-hydroxyundecylprodiginine (1b), 23-ketoundecylprodiginine (1c), and premarineosin (4) through heterologous expression of the entire mar gene cluster and/or gene replacement mutants in a heterologous host, S. venezuelae. Of these, the compound $\mathbf{4}$ antimalarial activity compares favorably with the most potent naturally occurring PGs and CQ.

The structural and functional diversity and promising antimalarial activity of these natural PGs and marineosins spurred us to synthesize various analogues of these lead molecules to obtain more active compounds. We recently reported the antimalarial activity of a large library of synthetic PGs. ${ }^{37,38}$ This work has shown that a terminal nonalkylated pyrrole

Received: April 9, 2015

Published: August 25, 2015 

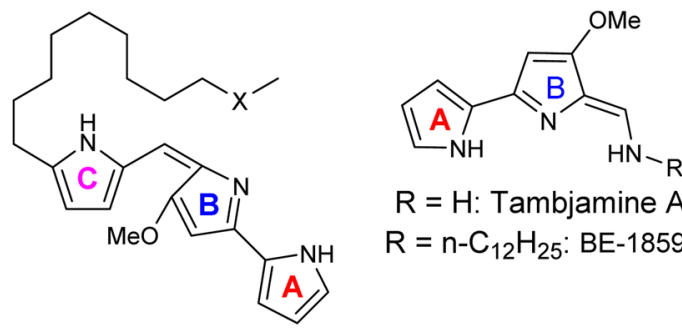

$\mathrm{R}=\mathrm{H}:$ Tambjamine $\mathrm{A}(\mathbf{2 a})$

$\mathrm{R}=\mathrm{n}-\mathrm{C}_{12} \mathrm{H}_{25}: \mathrm{BE}-18591(\mathbf{2 b})$<smiles>CCCC[C@@H]1C=C(Br)c2cc(c(/C=C3\N=C(c4ccc[nH]4)C=C3OC(C)(Br)Br)[nH]2)CCCCCC1</smiles>

$\mathrm{X}=\mathrm{CH}_{2}$ : Undecylprodiginine (UPG, 1a)

$\mathrm{X}=\mathrm{CH}-\mathrm{OH}:$ 23-Hydroxy-UPG (1b)

$X=C=0: 23-K e t o-U P G(1 c)$
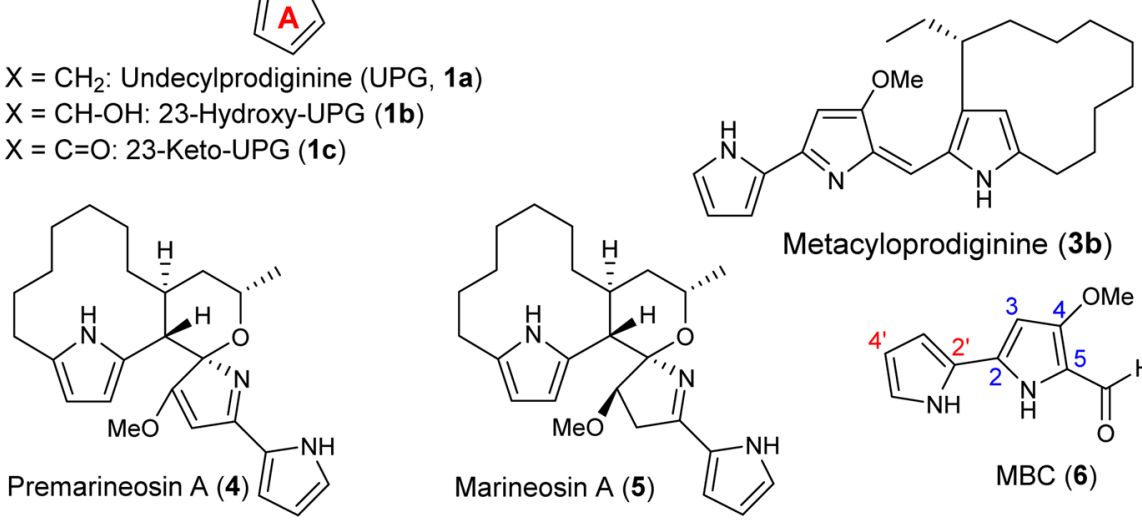

Metacyloprodiginine (3b)

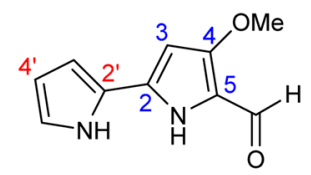

$\operatorname{MBC}(6)$

Figure 1. Structures of PPM natural products (1-5) and their common biosynthetic precursor (6).

(ring-A) and 3,5-dialkyl substitutions on the other terminal alkylated pyrrole (ring-C) of a natural tripyrrole PGs core structure are crucial for the potent antimalarial activity. A number of the synthetic PGs were effective at lower concentrations $\left(\mathrm{IC}_{50}=0.9-16.0 \mathrm{nM}\right)$ against $P$. falciparum strains, and their potency was more than the natural PGs and CQ. However, preliminary in vitro assays indicate concerns associated with the toxicity of PGs.

Our work on the potent antimalarial activity of $\mathrm{PGs}^{37,38}$ to date has been limited to SAR studies of A- and C-ring functionalized PGs. With a few exceptions, ${ }^{20,24,25,30,38}$ there have been no reports of a comprehensive series of TAs and B-ring functionalized PGs being prepared and evaluated for biological activities. In particular, the antimalarial activities of the TAs have not been reported to the best of our knowledge. These toxicity concerns for PGs and the intriguing biological activities of these PPM scaffolds have spurred us to expand the structural and functional diversity. Therefore, we have undertaken syntheses of novel TAs and B-ring functionalized PGs for enhanced antimalarial activity and reduced toxicity. To that end, we have developed new methods for the synthesis of various 2,2'-bipyrrole-5-carboxaldehydes ${ }^{53}$ and utilized in the generation of the novel TAs and B-ring functionalized PGs. Here we report the synthesis and structure-activity relationships (SARs) of TAs and B-ring functionalized PGs. The results show TAs with impressive in vitro potency and low toxicity and demonstrate that a tripyrrole structure is not required for activity. Furthermore, evidence of in vivo efficacy with TAs, including curative efficacy in mice after oral administration, is reported.

\section{RESULTS AND DISCUSSION}

Chemistry. The key precursors 6-43, which are involved in the synthesis of prodiginines (PGs) and tambjamines (TAs) (Scheme 10), are depicted in Figures 2 and 3. By use of literature methodologies, $\mathrm{MBC}(6)$ and analogue 21 were prepared from readily available 4-methoxy-3-pyrrolin-2-one in two steps ${ }^{54}$ and 2,2'-bipyrrole-5-carboxaldehydes 7, 8, and 10-18 were synthesized by our recent methods. ${ }^{53}$ The syntheses of various new pyrrole carboxaldehydes 9, 19, 20, and 22-39 are outlined in Schemes 1-9.

Synthesis of 4-(4-Chlorophenyl)-[2,2'-bipyrrole]-5carboxaldehyde (9). Synthesis of the aryl substituted 3-pyrrolin-2-one 48, a key synthon in the synthesis of bipyrrolecarboxaldehyde 9, began with the coupling of Boc-glycine (44) with 2,2-dimethyl-1,3-dioxane-4,6-dione (Meldrum's acid) to afford the acylated Meldrum's acid, which was further converted into the desired intermediate 45 by an intramolecular cyclization and a subsequent decarboxylation (Scheme 1). ${ }^{55}$ The compound 45 was treated with $p$-toluenesulfonyl chloride in the presence of $\mathrm{N}, \mathrm{N}$-diisopropylethylamine (DIPEA) to give the tosylated product 46 , in $89 \%$ yield, which was further subjected to Suzuki coupling reaction with 4-chlorophenylboronic acid to give the $\mathrm{N}$-Boc-4-aryl-3-pyrrolin-2-one 47 . The desired 4-aryl-3-pyrrolin-2-one $\mathbf{4 8}$ was obtained in excellent yield by deprotection of the $\mathrm{N}$-Boc group of 47 with trifluoroacetic acid. $^{56}$ By use of the reported Vilsmeier formylation method, ${ }^{54}$ 48 was then smoothly transformed to 5-bromo-3-(4-chlorophenyl)pyrrole-2-carboxaldehyde 49, which when further subjected to Suzuki coupling with $N$-Boc-2-pyrroleboronic acid followed by deprotection of the $N$-Boc group gave the desired 2,2'bipyrrole-5-carboxaldehyde 9 in 59\% yield (Scheme 1). ${ }^{53}$

Synthesis of 2,2'-Bipyrrole-5-carboxaldehyde (19). In 1988, Borger and Patel synthesized the 2,2'-bipyrrole-5carboxaldehyde (19) in seven steps. ${ }^{12}$ In this work, we successfully accomplished 19 in two one-pot sequences from easily available pyrrole (50), as shown in Scheme 2. To that end, compound $\mathbf{5 0}$ was consecutively treated with $\mathrm{N}$-chlorosuccinimide (NCS) and Vilsmeier reagent $\left(\mathrm{POCl}_{3} / \mathrm{DMF}\right.$, in situ generation) under controlled temperatures to obtain the 5-chloro-pyrrole-2carboxaldehyde (51) in good yield. ${ }^{57}$ The Suzuki cross-coupling of 51 with $\mathrm{N}$-Boc-2-pyrroleboronic acid followed by deprotection of the $N$-Boc group provided the desired bipyrrolecarboxaldehyde 19 in $45 \%$ isolated yield (Scheme 2).

Synthesis of 3-(Pyrrol-2-yl)-4,5,6,7-tetrahydroisoindole-1-carboxaldehyde (20). The key intermediate 53 was prepared via BartoneZard's method, using 1-nitro-1-cyclohexene (52) as a starting material (Scheme 3). ${ }^{53,58,59}$ Upon treatment with $\mathrm{NaOH}$ in ethylene glycol under reflux, $\mathbf{5 3}$ was 
<smiles>C=Cc1[nH]c(-c2ccc[nH]2)cc1OC</smiles>

6<smiles>Cc1cc(C=O)[nH]c1-c1ccc[nH]1</smiles><smiles>Cc1c(C=O)[nH]c(-c2ccc[nH]2)c1C</smiles>

14<smiles>CCc1c(C=O)[nH]c(-c2ccc[nH]2)c1Cl</smiles><smiles>Cc1cc(-c2ccc[nH]2)[nH]c1C=O</smiles>
7<smiles>CCc1cc(C=O)[nH]c1-c1ccc[nH]1</smiles>
11<smiles>CCc1c(C=O)[nH]c(-c2ccc[nH]2)c1CC</smiles>

15<smiles>O=Cc1ccc(-c2ccc[nH]2)[nH]1</smiles>

19<smiles>CCc1cc(-c2ccc[nH]2)[nH]c1C=O</smiles><smiles>CC(C)c1cc(C=O)[nH]c1-c1ccc[nH]1</smiles>
12<smiles>CCc1c(C=O)[nH]c(-c2ccc[nH]2)c1C</smiles>
16<smiles>O=Cc1[nH]c(-c2ccc[nH]2)c2c1CCCC2</smiles><smiles>O=Cc1[nH]c(-c2ccc[nH]2)cc1-c1ccc(Cl)cc1</smiles><smiles>CC(C)(C)c1cc(C=O)[nH]c1-c1ccc[nH]1</smiles>

13<smiles>CCc1c(-c2ccc[nH]2)[nH]c(C=O)c1C</smiles>

Figure 2. Key precursors (6-20) for the synthesis of B-ring functionalized PGs and TAs.<smiles>CCn1cccc1-c1cc(OC)c(C=O)[nH]1</smiles><smiles>Cc1c(C=O)[nH]c(-c2cccn2C)c1C</smiles><smiles>Cc1c(C=O)[nH]c(-c2ccccc2)c1C</smiles><smiles>CCc1c(C)[nH]c(-c2[nH]c(C=O)c(C)c2C)c1C</smiles><smiles>Cc1[nH]c(C=O)c2c1CCCC2</smiles><smiles>CCCc1c(C=O)[nH]c(C=O)c1CC</smiles><smiles>Cc1c(C=O)[nH]c(-c2cc3ccccc3[nH]2)c1C</smiles><smiles>O=Cc1[nH]c(-c2ncc[nH]2)c2c1CCCC2</smiles><smiles>O=Cc1ccc[nH]1</smiles><smiles>Cc1c(C=O)[nH]c(-c2cc[nH]c2)c1C</smiles><smiles>CCc1ccc(-c2[nH]c(C=O)c(C)c2C)[nH]1</smiles>

32<smiles>CCc1c[nH]c(-c2[nH]c(C=O)c(C)c2C)c1</smiles><smiles>CCc1c(-c2ccc[nH]2)c[nH]c1C=O</smiles><smiles>Cc1c(C=O)[nH]c(-c2cccs2)c1C</smiles><smiles>Cc1c(C=O)[nH]c(-c2ccc(CC(C)C)[nH]2)c1C</smiles><smiles>Cc1cc(C)c(-c2[nH]c(C=O)c(C)c2C)[nH]1</smiles><smiles>CCCCCCCCCC=O</smiles><smiles>CCc1c(C)[nH]c(C=O)c1C</smiles>

Figure 3. Key precursors (21-43) for the synthesis of A- and B-ring functionalized PGs and TAs.

smoothly converted to 4,5,6,7-tetrahydroisoindole (54) in $90 \%$ yield by successive hydrolysis and decarboxylation of the ester group. ${ }^{53}$ Using the standard Vilsmeier formylation method, $\mathbf{5 4}$ was then transformed to 4,5,6,7-tetrahydroisoindole-1-carboxaldehyde (55), which when further treated with 1,3-dibromo-5,5-dimethylhydantoin (DBDMH) ${ }^{53}$ in THF at $-78{ }^{\circ} \mathrm{C}$ to room temperature provided the 3-bromo-4,5,6, 7-tetrahydroisoindole-1-carboxaldehyde (56). Subsequently, Suzuki cross-coupling reaction between 56 and N-Boc-2pyrroleboronic acid and further deprotection of the $N$-Boc group led to the desired bipyrrolecarboxaldehyde $\mathbf{2 0}$ in good yield (Scheme 3).
Synthesis of Isomeric [2,3'-Bipyrrole]-5'-carboxaldehydes (22-25). To investigate the ring-A positional effect on antimalarial activity, the isomeric bipyrrolecarboxaldehydes 22-25 were prepared, as shown in Scheme 4. Pyrrole-2carboxaldehyde (40) and 3,5-dimethylpyrrole-2-carboxaldehyde (42) were obtained from commercial sources, and the 3methylpyrrole-2-carboxaldehyde (57) and 3-ethylpyrrole-2carboxaldehyde (58) were prepared according to our reported procedures. $^{53}$ These pyrrole-2-carboxaldehydes were then converted into the corresponding 4-bromopyrrole-2-carboxaldehydes 59-62 via a regioselective bromination at 4-position using DBDMH in THF in good yields (Scheme 4). ${ }^{53}$ These 
Scheme 1. Synthesis of 4-(4-Chlorophenyl)-[2,2'-bipyrrole]-5-carboxaldehyde (9)

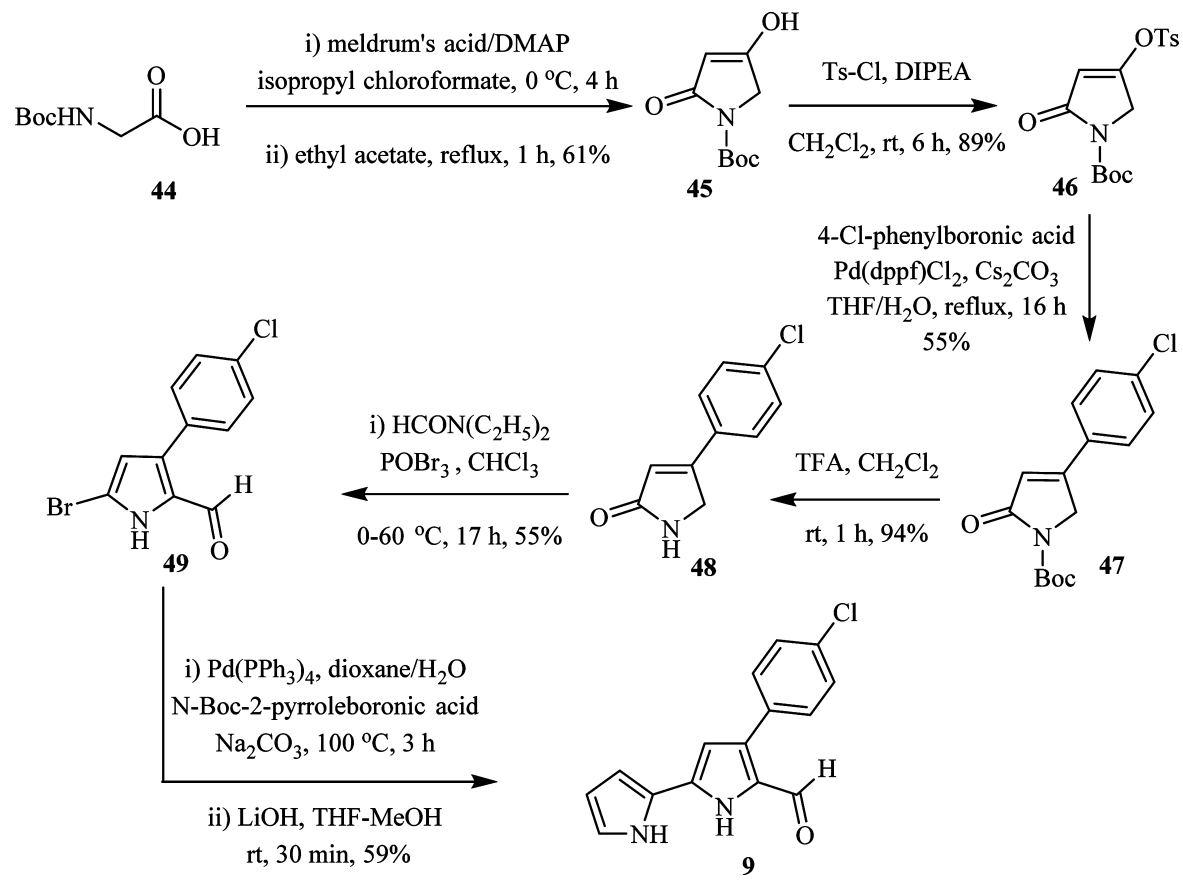

Scheme 2. Synthesis of 2,2'-Bipyrrole-5-carboxaldehyde (19)

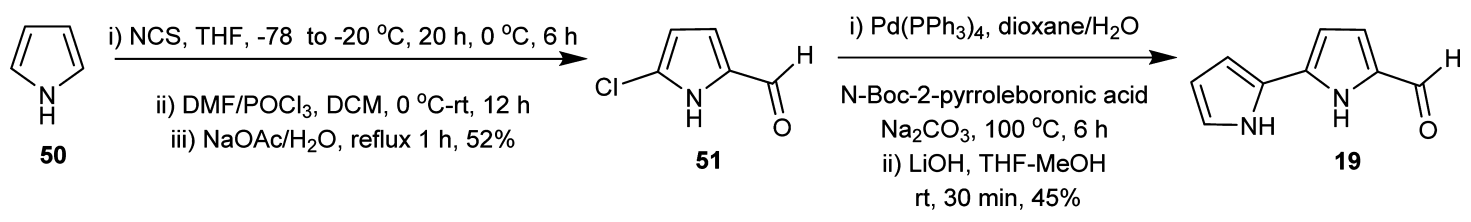

Scheme 3. Synthesis of 3-(Pyrrol-2-yl)-4,5,6,7-tetrahydroisoindole-1-carboxaldehyde (20)
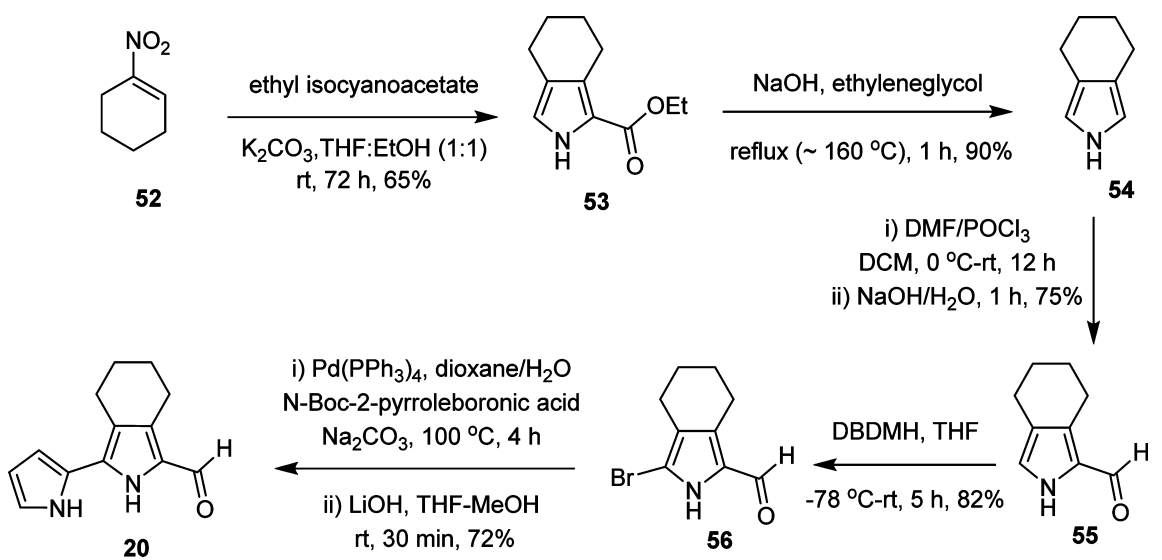

Scheme 4. Synthesis of Isomeric [2,3'-Bipyrrole]-5'-carboxaldehydes (22-25)<smiles>[R]c1cc([R2])c(C=O)[nH]1</smiles>

40: $R_{1}=R_{2}=H$

42: $R_{1}=R_{2}=M e$

57: $R_{1}=H, R_{2}=M e$

58: $R_{1}=H, R_{2}=E t$
59: $R_{1}=R_{2}=H(75 \%)$

60: $R_{1}=R_{2}=\operatorname{Me}(78 \%)$

61: $R_{1}=H, R_{2}=M e(79 \%)$

62: $R_{1}=H, R_{2}=E t(83 \%)$

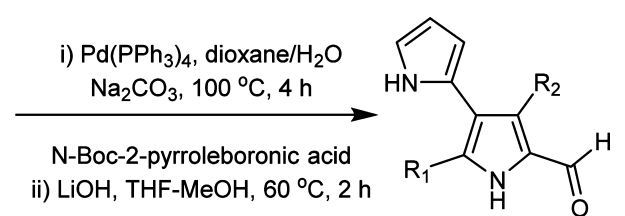

22: $R_{1}=R_{2}=H(70 \%)$

23: $R_{1}=R_{2}=\operatorname{Me}(72 \%)$

24: $R_{1}=H, R_{2}=M e(67 \%)$

25: $R_{1}=H, R_{2}=E t(65 \%)$ 
Scheme 5. Synthesis of MBC's analogues containing heteroaryl/aryl groups in the place of ring-A (26-31)

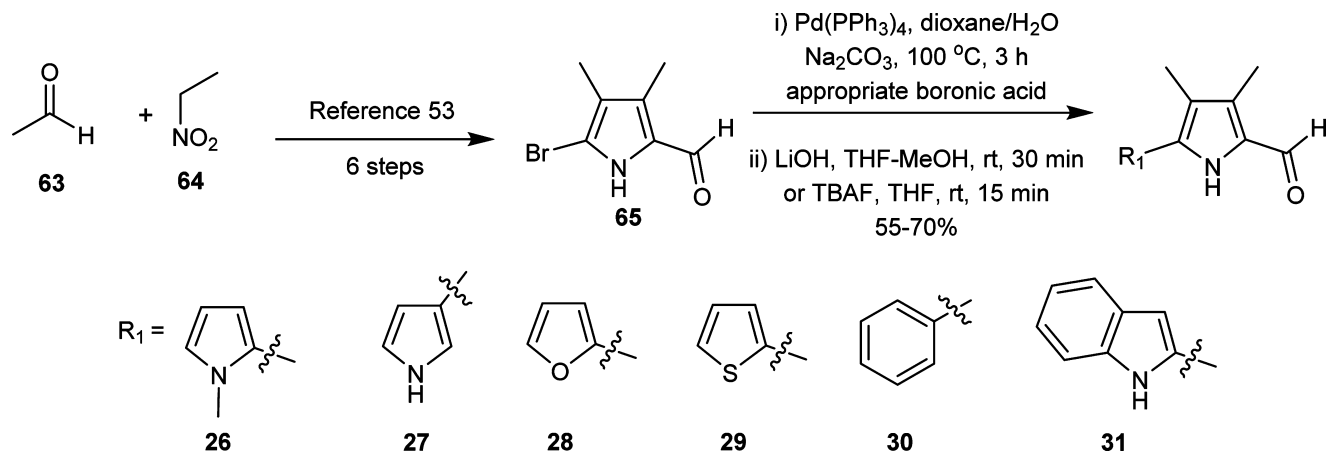

Scheme 6. Synthesis of 3,4-Dimethyl-[2,2'-bipyrrole]-5-carboxaldehydes Where the Ring-A Contains C-Alkyl Groups (32-35)

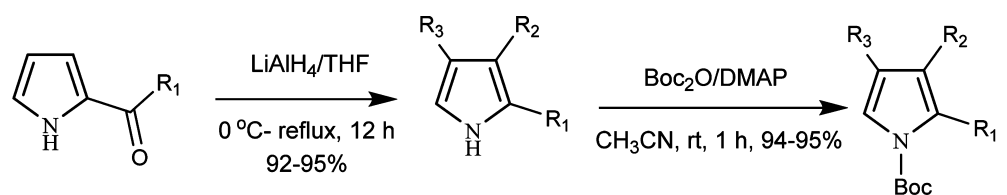

66a: $\mathrm{R}_{1}=\mathrm{Me}$ 66b: $\mathrm{R}_{1}=i-\mathrm{Pr}$ 67a: $R_{1}=E t, R_{2}=R_{3}=H$ 67b: $\mathrm{R}_{1}=i-\mathrm{Bu}, \mathrm{R}_{2}=\mathrm{R}_{3}=\mathrm{H}$ 67c: $R_{1}=R_{3}=M e, R_{2}=H$ 67d: $R_{1}=R_{3}=M e, R_{2}=E t$ 68a: $R_{1}=E t, R_{2}=R_{3}=H$ 68b: $\mathrm{R}_{1}=i-\mathrm{Bu}, \mathrm{R}_{2}=\mathrm{R}_{3}=\mathrm{H}$ 68c: $R_{1}=R_{3}=M e, R_{2}=H$ 68d: $R_{1}=R_{3}=M e, R_{2}=E t$

n-BuLi/2,2,6,6-tetramethylpiperidine trimethyl borate, THF, $-78^{\circ} \mathrm{C}-\mathrm{rt}, 24 \mathrm{~h}$ $65-85 \%$

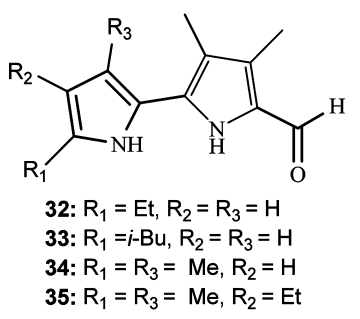

i) $65, \mathrm{Pd}\left(\mathrm{PPh}_{3}\right)_{4}$, dioxane $/ \mathrm{H}_{2} \mathrm{O}$ $\mathrm{Na}_{2} \mathrm{CO}_{3}, 100^{\circ} \mathrm{C}, 3 \mathrm{~h}$

ii) $\mathrm{LiOH}, \mathrm{THF}-\mathrm{MeOH}, \mathrm{rt}, 30 \mathrm{~min}$ $75-77 \%$<smiles>[R]c1c([R])c(B(O)O)n(C(=O)OCc2ccccc2)c1[R]</smiles>

69a: $R_{1}=E t, R_{2}=R_{3}=H$ 69b: $\mathrm{R}_{1}=i$-Bu, $\mathrm{R}_{2}=\mathrm{R}_{3}=\mathrm{H}$ 69c: $R_{1}=R_{3}=M e, R_{2}=H$ 69d: $R_{1}=R_{3}=M e, R_{2}=E t$

Scheme 7. Synthesis of $4^{\prime}$-Ethyl-3,4-dimethyl-[2,2'-bipyrrole]-5-carboxaldehyde (36)

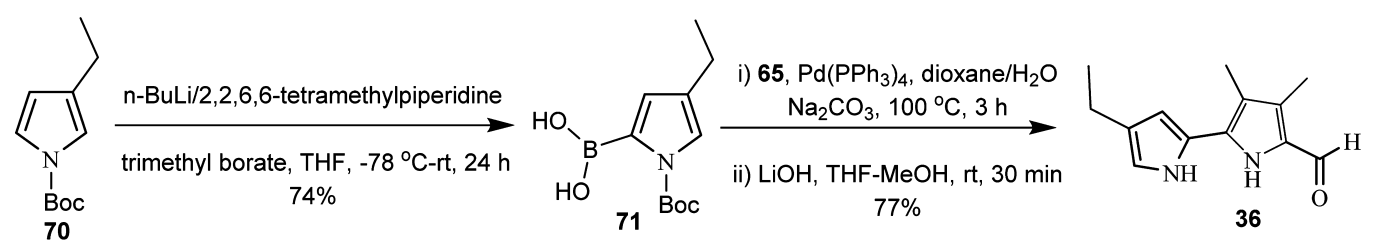

4-bromopyrrole-2-carboxaldehydes 59-62 were further subjected to Suzuki coupling reaction with $\mathrm{N}$-Boc-2-pyrroleboronic acid, and a subsequent treatment with $\mathrm{LiOH}$ in $\mathrm{THF} / \mathrm{MeOH}$ (1:1) at $60{ }^{\circ} \mathrm{C}$ resulted in the desired isomeric bipyrrolecaraboxaldehydes 22-25 (Scheme 4).

Synthesis of MBC's Analogues (26-31) Containing Herteroaryl/Aryl Groups in the Place of Ring-A. To probe the exact role of the 2-pyrrolyl moiety (ring-A) on activity, we have prepared various key carboxaldehyde precursors 26-31 in which the ring-A is completely replaced by various heterocycles and/or aryl moieties and the ring-B is substituted with short alkyl groups (Scheme 5). The 5-bromo-3,4-dimethylpyrrole-2carboxaldehyde (65) was prepared in six steps according to the literature methods from acetaldehyde (63) and nitroethane $(64),{ }^{53}$ and it was subsequently subjected to Suzuki coupling reaction with various boronic acids, and further deprotection of the Boc/TIPS group led to the corresponding carboxaldehydes 26-31 (Scheme 5).

Synthesis of 3,4-Dimethyl-[2,2'-bipyrrole]-5-carboxaldehydes Where Ring-A Contains C-Alkyl Groups (32-36). To investigate the effect of the ring-A alkyl substituents pattern on potency, we have prepared various alkylated bipyrrolecarboxaldehyde precursors 32-36, as shown in Schemes 6 and 7. The 2-acetylpyrrole (66a), 2,4-dimethylpyrrole (67c), and 3-ethyl-2,4-dimethylpyrrole $(67 \mathrm{~d})$ were obtained from commercial sources, and the 2-isobutyrylpyrrole (66b) was prepared according to the literature methods. ${ }^{60}$ The compounds 66a and $66 \mathrm{~b}$ were then converted into the corresponding 2-alkylpyrroles $67 \mathrm{a}$ and $67 \mathrm{~b}$, respectively, using $\mathrm{LiAlH}_{4}$ in THF under reflux (Scheme 6). ${ }^{61}$ By use of standard procedures, the $N$-Boc-protected pyrroles $\mathbf{6 8 a}-\mathbf{d}$ were prepared in excellent yields from $67 \mathbf{a}-\mathbf{d}$ using di-tert-butyl dicarbonate $\left(\mathrm{Boc}_{2} \mathrm{O}\right)$ in 
Scheme 8. Synthesis of 3-(Imidazol-2-yl)-4,5,6,7-tetrahydroisoindole-1-carboxaldehyde (37)

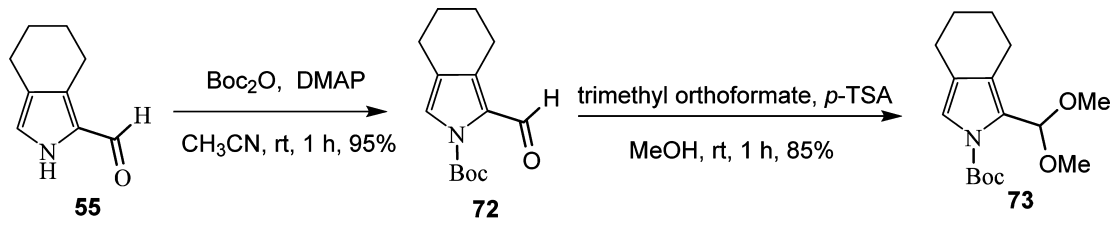

55

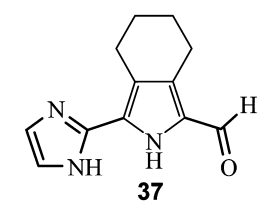

72

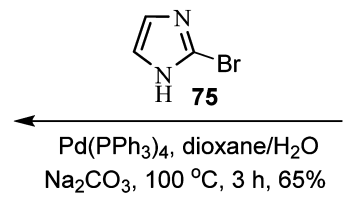

i) LDA, triisopropyl borate $\mathrm{THF}, 0^{\circ} \mathrm{C}, 1 \mathrm{~h}$ ii) aq. $\mathrm{KHSO}_{4} / \mathrm{NH}_{4} \mathrm{Cl}$ $\mathrm{rt}, 2 \mathrm{~h}, 94 \%$<smiles>O=Cc1[nH]c(B(O)O)c2c1CCCC2</smiles>

Scheme 9. Synthesis of 3-Methyl-4,5,6,7-tetrahydroisoindole-1-carboxaldehyde (38) and 5,5'-Methylenebis(4-ethyl-3methylpyrrole-2-carboxaldehyde) (39)

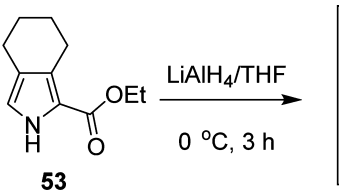

53

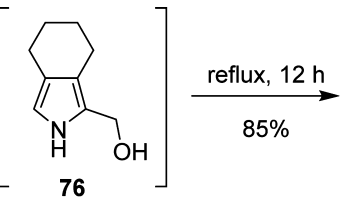

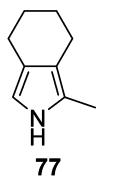

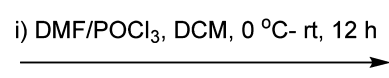

ii) $\mathrm{NaOH} / \mathrm{H}_{2} \mathrm{O}, \mathrm{rt}, 1 \mathrm{~h}, 76 \%$

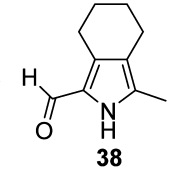

38

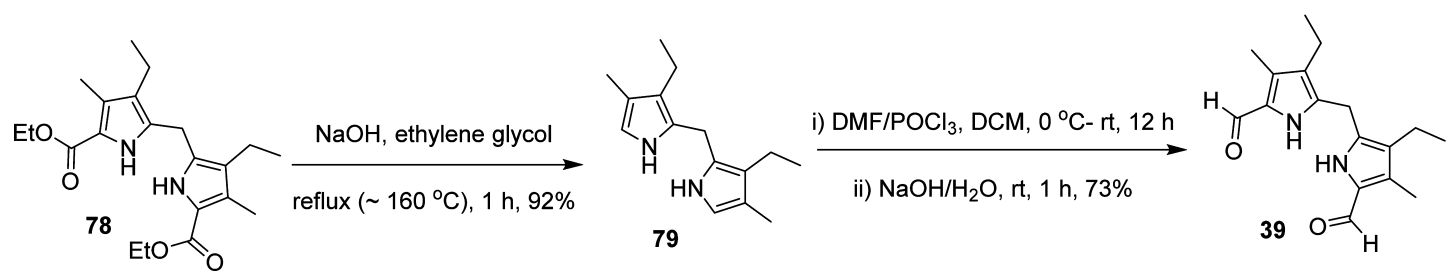

the presence of 4-dimethylaminopyridine (DMAP), and subsequently these were converted into the corresponding 5-alkyl(1-tert-butoxycarbonylpyrrol-2-yl)boronic acids $69 a-d .{ }^{62}$ The resultant boronic acids $69 \mathbf{a}-\mathbf{d}$ were carried forward into the Suzuki coupling reaction with $\mathbf{6 5}$ without further purification to afford their corresponding [2,2'-bipyrrole]-5-carboxaldehydes 32-35 in good yields (Scheme 6).

We have also developed a simple and convenient method for the synthesis of $\mathrm{N}$-Boc-4-ethyl-2-pyrrolboronic acid (71) via a regioselective boronylation of N-Boc-3-ethylpyrrole (70), , $^{53}$ using $n$-BuLi/2,2,6,6-tetramethylpiperidine and trimethyl borate (Scheme 7, Experimental Section). Further investigations to expand the substrate scope of the regioselective boronylation as well as mechanistic studies are underway in our laboratory. Finally the 4'-ethyl-3,4-dimethyl-[2,2'-bipyrrole]-5-carboxaldehyde (36) was prepared in good yield via Suzuki coupling of 65 with boronic acid 71, followed by the deprotection of $N$-Boc group with $\mathrm{LiOH}$ (Scheme 7). The final compound 36 was fully characterized by extensive 2D NMR analysis (see Supporting Information).

Synthesis of 3-(Imidazol-2-yl)-4,5,6,7-tetrahydroisoindole-1-carboxaldehyde (37). To investigate the role of ring-A with an extra nitrogen atom on potency, we have replaced the ring-A by imidazole moiety, as in 37 (Scheme 8). The $\mathrm{N}$-Bocpyrrole $\mathbf{7 2}$ was prepared in $95 \%$ yield from compound $\mathbf{5 5}$ using $\mathrm{Boc}_{2} \mathrm{O} / \mathrm{DMAP}$, and subsequently the aldehyde group was protected by trimethyl orthoformate under acidic conditions to obtain the desired intermediate 73 . The compound 73 was further reacted with triisopropyl borate/LDA in THF and followed by aqueous solution of $\mathrm{KHSO}_{4} / \mathrm{NH}_{4} \mathrm{Cl}$ at room temperature to provide the desired boronic acid 74 in excellent yield. ${ }^{53}$ Finally, the Suzuki cross-coupling reaction between $\mathbf{7 4}$ and 2-bromoimidazole (75) and subsequent deprotection of the $N$-Boc group led to the desired carboxaldehyde 37 in $65 \%$ isolated yield (Scheme 8).

Synthesis of 3-Methyl-4,5,6,7-tetrahydroisoindole-1carboxaldehyde (38) and 5,5'-Methylenebis(4-ethyl-3methylpyrrole-2-carboxaldehyde) (39). We wanted to study the analogues of TAs without ring-A; therefore, two representative pyrrole aldehydes 38 and 39 (Scheme 9) were synthesized. Initially, 1-methyl-4,5,6,7-tetrahydroisoindole (77) was synthesized from ethyl-4,5,6,7-tetrahydroisoindole-1-carboxylate (53) via an unstable intermediate 76, using $\mathrm{LiAlH}_{4}$ in THF at $0{ }^{\circ} \mathrm{C}$ to room temperature in $85 \%$ isolated yield. The resultant alkylpyrrole 77 was further converted to 3-methyl4,5,6,7-tetrahydroisoindole-1-carboxaldehyde (38) by Vilsmeier reagent $\left(\mathrm{POCl}_{3} / \mathrm{DMF}\right)$ (Scheme 9). Conversely, the bis(3-ethyl4-methylpyrrol-2-yl)methane (79) was prepared from diethyl5,5'-methylenebis(4-ethyl-3-methyl-2-pyrrolecarboxylate) (78) in excellent yields via a successive hydrolysis and a decarboxylation of the ester groups. Further Vilsmeier formylation of $\mathbf{7 9}$ provided the desired dicarboxaldehyde 39 in $73 \%$ isolated yield (Scheme 9).

Synthesis of Novel PGs (85-98) and TAs (99-187). By use of our standardized procedures, the mono- and dialkyl/alkylaryl pyrroles 80-84 were synthesized (Figure 4). ${ }^{37}$ The acid-catalyzed 
<smiles>Clc1ccc(Cc2c[nH]c(Cc3ccc(Cl)cc3)c2)cc1</smiles>

80
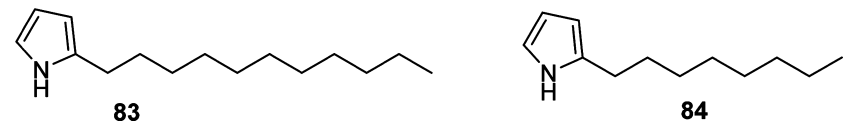

Figure 4. Potential substrates $(\mathbf{8 0 - 8 4})$ for the synthesis of PGs.

condensation of either the alkylpyrroles $80-84$ or the commercially available alkyl/arylamines with various bipyrrolecarboxaldehydes and analogues 6-43 provided the desired PGs 85, 86, 88-98 and TAs 99-187, respectively, in good to excellent isolated yields (Scheme 10). The PG $\mathbf{8 5}$ was further treated with $\mathrm{MeI} / \mathrm{NaH}$ in DMF to provide the $\mathrm{N}, \mathrm{N}$-dimethyl PG 87 in $85 \%$ isolated yield (Scheme 10).

Synthesis of TA-like Analogues (190, 191, and 194-196). Distinct syntheses were designed and executed to obtain a different class of TA-like analogues 190, 191, and 194-196, in which the crucial ring-B of TAs is completely replaced by an alkylamide/amine linkage (Scheme 11). To that end, compound 188 was synthesized via a standard condensation method (EDCl/DMAP) from 44 and 1-adamantylamine in $85 \%$ yield. Removal of the Boc group of $\mathbf{1 8 8}$ by trifluoroacetic acid/water (1:1) provided the intermediate 189 in good yield, ${ }^{63}$ which was further utilized in a condensation reaction with pyrrole-2carboxylic acid to furnish the desired product 190. Treatment of 190 with $\mathrm{LiAlH}_{4}$ in THF at $0{ }^{\circ} \mathrm{C}$ to reflux conditions gave the 191 in $82 \%$ isolated yield (Scheme 11). Conversely, analogues 194-196 were also synthesized, as shown in Scheme 11. The pyrrole-2-carboxaldehyde (40) was subjected to HornerWadsworth-Emmons (HWE) reaction with methyl diethylphosphonoacetate in the presence of $\mathrm{NaH}$ to obtain the methyl-3-(pyrrol-2-yl)acrylate (192), ${ }^{64,65}$ which when hydrolyzed under basic $\left(\mathrm{LiOH} \cdot \mathrm{H}_{2} \mathrm{O}\right)$ conditions, furnished the 2-pyrrolylacrylic acid 193. Condensation of 193 with 189 in the presence of $\mathrm{EDCl} / \mathrm{DMAP}$ led to the corresponding condensed product 194, which was further treated with $\mathrm{NaBH}_{4} / \mathrm{NiCl}_{2} \cdot 6 \mathrm{H}_{2} \mathrm{O}$ to give the saturated product 195 . Treatment of 195 with $\mathrm{LiAlH}_{4}$ in THF at $0{ }^{\circ} \mathrm{C}$ to reflux conditions provided the desired product 196 in $78 \%$ yields (Scheme 11).
Biological Activity. In this work, the structure-activity relationships (SARs) focused on various substitutions and positions of the ring-A and $-\mathrm{B}$ and the nature of the alkylamines of TAs, and ring-B of PGs. Specifically, the modifications to the ring-B of TAs and PGs were designed in order to understand the structural requirements, as well as the necessity of the ring-B for the potent antimalarial activity. We have synthesized various series of novel TAs and B-ring functionalized PGs and evaluated for antimalarial activity against the chloroquinesensitive $\left(C^{S}\right)$ D6 and the chloroquine-resistant $\left(C^{R}\right) \operatorname{Dd} 2$ and $7 \mathrm{G} 8$ strains of $P f$ with chloroquine (CQ) as a reference drug. ${ }^{66,67}$ In parallel, the cytotoxicity of the most potent antimalarial PGs and TAs $\left(\mathrm{IC}_{50}<250 \mathrm{nM}\right)$ was tested against hepatocellular HepG2 cancer cell line using mefloquine (MQ) as a control drug (see Tables 1-6). ${ }^{68,69}$

In Vitro Antimalarial Activity of PGs (85-98). In our previous work, synthetic PG $\mathbf{8 5}$ had shown an excellent potency against $P f$ strains $\mathrm{D} 6\left(\mathrm{CQ}^{\mathrm{S}}\right)$ and $\mathrm{Dd} 2\left(\mathrm{CQ}^{\mathrm{R}}\right)$ with great $\mathrm{IC}_{50}$ values (Table 1) and had the most favorable profile: $92 \%$ parasite reduction at $5 \mathrm{mg} \mathrm{kg}^{-1}$ day $^{-1}, 100 \%$ reduction at $25 \mathrm{mg} \mathrm{kg}^{-1} \mathrm{day}^{-1}$ in a $P$. yoelii murine patent infection without any evident weight loss or clinical overt toxicity. ${ }^{37}$ To explore the $N$-alkyl effect on potency, initially we synthesized two $\mathrm{N}$-methylated analogues 86 and 87 of the $\mathbf{8 5}$ (Table 1). These compounds 86 and 87 led to a large decrease in the antimalarial activity $\left(\mathrm{IC}_{50}>2250 \mathrm{nM}\right)$ against three $P$ f strains $\mathrm{D} 6, \mathrm{Dd} 2$, and $7 \mathrm{G} 8$, demonstrating that both pyrrole $\mathrm{NH}$ groups (ring-A and $-C$ ) of the PGs are required for potent antimalarial activity, supporting our previous findings. ${ }^{38}$ To investigate the importance of the methoxy group (OMe) on ring- $\mathrm{B}$, two analogues 88 and 89 , in which the OMe group is replaced by 4-chlorophenyl moiety and hydrogen (complete removal of $\mathrm{OMe}$ ), respectively, were prepared and examined for in vitro antimalarial activity. A dramatic loss of potency was observed for both compounds $\mathbf{8 8}$ and $\mathbf{8 9}$, which have an $\mathrm{IC}_{50}$ of $>2500 \mathrm{nM}$ against all tested $P f$ strains (Table 1). Interestingly, while replacing the OMe group by ethyl unit as in $\mathbf{9 0}$ also led to the reduced potency $\left(90 \mathrm{IC}_{50}=101 \mathrm{nM}\right.$ versus $1 \mathrm{a} \mathrm{IC}$ against D6), the reduction was modest (14-fold). This result demonstrated that a short aliphatic substitution at 4-position on the ring- $\mathrm{B}$ could replace the OMe group and retain activity. Together, these results highlighted the importance of the $\mathrm{OMe}$ or short alkyl group on the ring-B of PGs for potent antimalarial activity, supporting our previous findings. ${ }^{38}$

We next investigated whether substitutions at 2 and 3 positions of the ring-B are tolerated. A series of novel B-ring functionalized PGs 91-98, in which the ring-B is substituted with

\section{Scheme 10. Synthesis of Novel PGs (85-98) and TAs (99-187)}

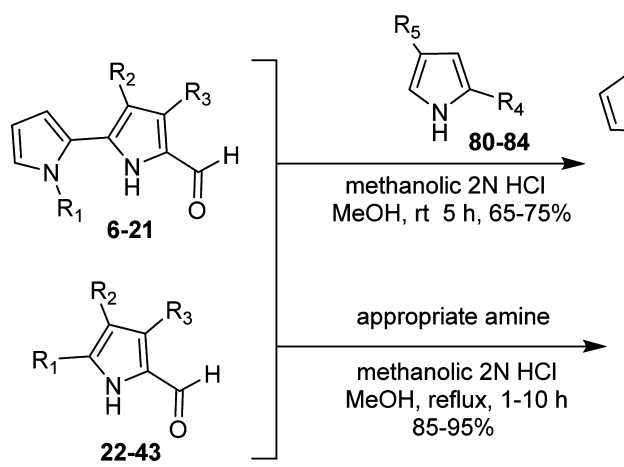<smiles>[R3]C1=C([R3])/C(=C/c2[nH]c([R6])cc2[R5])N=C1c1cccn1[R7]</smiles>

85, 86, and 88-98<smiles>[R]N/C=C1\N=C([R])C([R])=C1[R9]</smiles><smiles>[R]C1=C([R])/C(=C/c2c([R6])cc([R])n2C)N=C1c1cccn1C</smiles>

87

$R_{1}-R_{5}=$ Various substituents 
Scheme 11. Synthesis of Novel Analogues (190, 191, and 194-196)

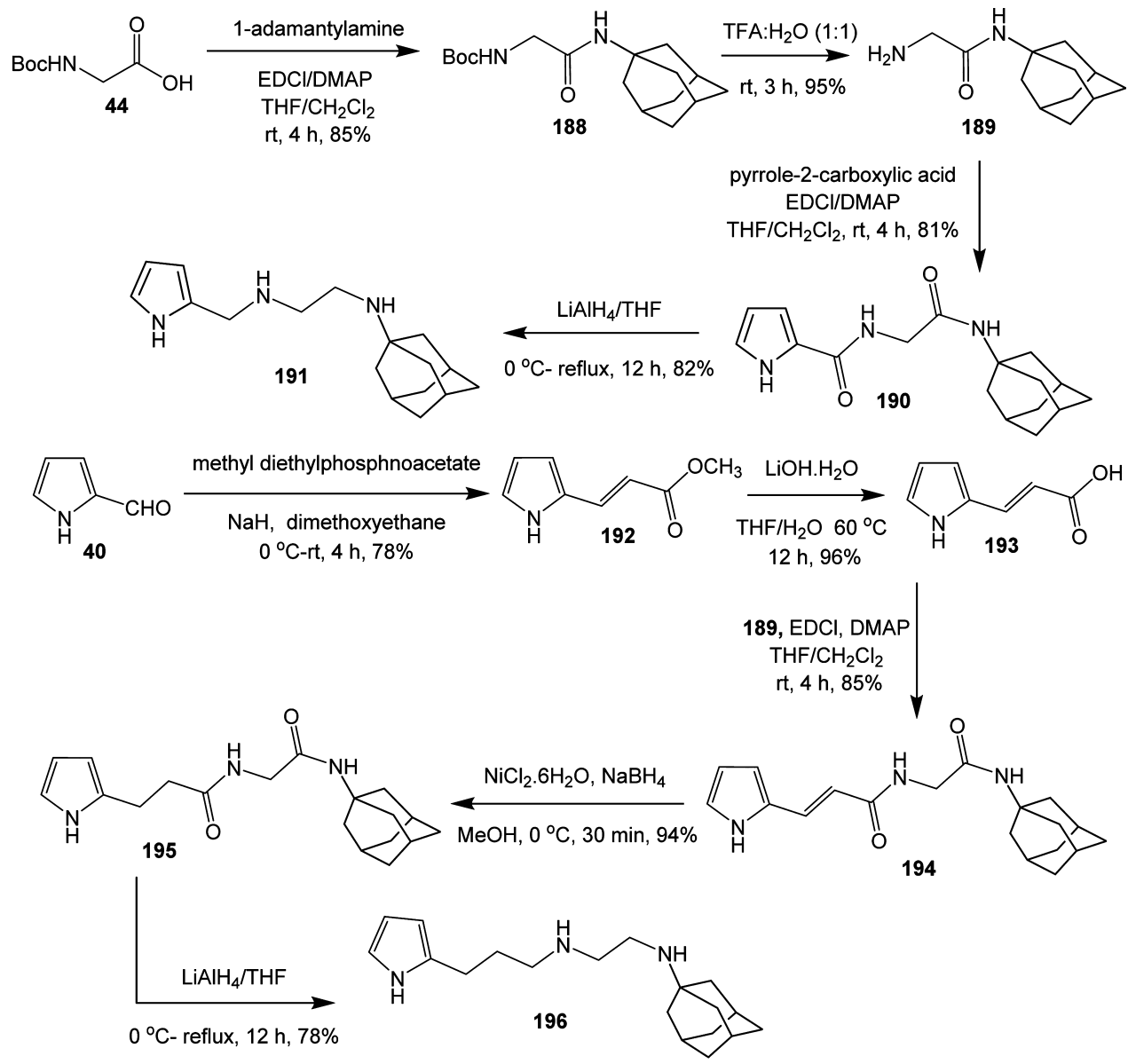

either mono- and/or disubstituents at 3- and 4-positions, were generated and examined for their in vitro antimalarial activity (Table 1). A significant loss of potency $\left(\mathrm{IC}_{50}>1500 \mathrm{nM}\right)$ was observed for 91 and 92, containing an isopropyl and tert-butyl groups, respectively, at 3 -position on the ring- $B$. The adverse effect of the substitutions at 3-position on the ring-B was further confirmed by the introduction of the chloro $(\mathrm{Cl})$ substitution at 3-position of 90 , as with the analogue 93 , which had an $\mathrm{IC}_{50}$ of $>2500 \mathrm{nM}$ against all strains $\left(90 \mathrm{IC}_{50}=101 \mathrm{nM}\right.$ versus $93 \mathrm{IC}_{50}>2500 \mathrm{nM}$ ), suggesting that the rigid bulky substitutions or chlorine moiety (EWG) at 3-position are not preferred (Table 1). To further investigate the impact of the short alkyl substituents at both the 3- and 4-positions on ring-B, a set of mixed analogues 94-98, which contain the 3-ethyl/ 4-methyl groups on the ring-B, was examined. Analogues 94 and 95, which have monoalkyl groups at 5-position of the ring-C, showed a roughly 20 -fold drop in activity as compared to undecylprodiginine (1a) (Table 1). Conversely, the analogue 96 containing a monoalkyl group at 3-position on the ring-C, showed higher potency (3-fold) than 95 against all tested $P f$ strains, while it had 9-fold lesser potency than the corresponding $\mathrm{OMe}$ group containing analogue $\left(\mathrm{IC}_{50}=4.6 \mathrm{nM}\right.$ against $\mathrm{D} 6^{37}$ ). Interestingly, the analogue 97, which has 3-alkyl and 5 -alkylaryl substituents on the ring-C, was equipotent to the $\mathbf{8 5}$, while the analogue 98, which has 3,5-dialkylaryl substituents on ring-C, showed $\sim 5$-fold lower potency when compared to the corresponding OMe group containing analogue 85 (Table 1). Again these results are consistent and support the findings that the 3,5-disubstitutions on ring- $\mathrm{C}$ are very important for potent activity. ${ }^{37}$ In summary, these SAR analyses of the ring-B functionalized PGs demonstrate that the short alkyl substitutions are well tolerated at 3/4-positions on the ring-B.

In Vitro Antimalarial Activity of 4-Substituted B-Ring Functionalized TAs (99-129). Having determined the substituents impact on the antimalarial activity of the PGs (through this and previous work ${ }^{37,38}$, we subsequently tested a hypothesis that the complete replacement of the right-hand-side alkylated pyrrole (ring-C) of PGs by alkylamines, providing the TAs, might represent an opportunity to make potent and selective antimalarials with the desired "druglike" properties. Specifically, lower molecular weight (MWT) and lipophilic properties $(\log P)$ are the two key characteristics that determine adsorption, distribution, metabolism, excretion, and toxicity (ADMET) liabilities, with some ADMET parameters depending more on MWT and some on $\log P .^{70}$ Subsequent TA analogues 99-129 (Table 2), which have lower MWT $(<400)$ and $c \operatorname{LogP}(<4.2$, except 114), were generated to obtain a SAR for the alkylamines in the place of ring- $\mathrm{C}$ and substituents at 4-position on the ring-B.

Initially, a series of new TAs 99-112, which have various alkyl/arylamines in the place of ring- $\mathrm{C}$ and the $\mathrm{OMe}$ group at the 4-position on the ring-B (as in natural products), were synthesized and evaluated for their in vitro antimalarial activity against $P f$ strains, and the results are shown in Table 2. TAs 99-102 containing the $n$-alkylamines in the place of ring-C exhibited good activity against all $P f$ strains; specifically, analogues 100 and 102 showed the highest potencies $\left(\mathrm{IC}_{50}<50 \mathrm{nM}\right)$ (Table 2). To probe the effect of cycloalkylamines in the place 
Table 1. In Vitro Antimalarial Activity and Cytotoxicity of PGs (85-98)
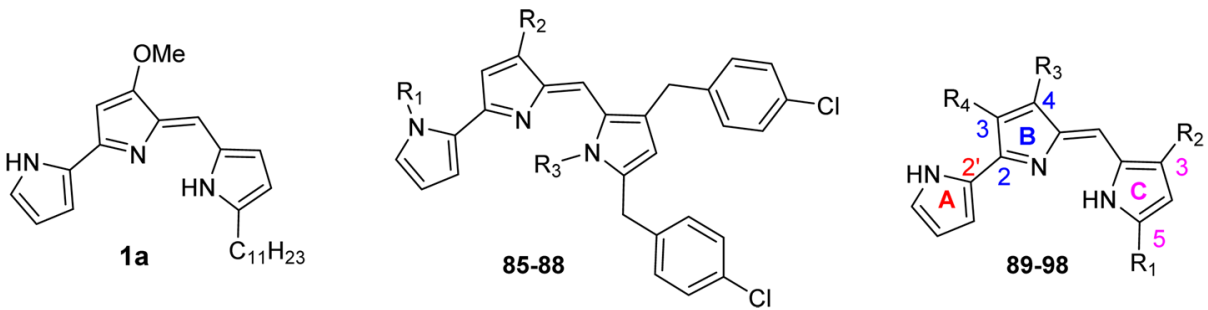

\begin{tabular}{|c|c|c|c|c|c|c|c|c|c|c|}
\hline \multirow[b]{2}{*}{ compd } & \multirow[b]{2}{*}{$\mathrm{R}_{1}$} & \multirow[b]{2}{*}{$\mathrm{R}_{2}$} & \multirow[b]{2}{*}{$\mathrm{R}_{3}$} & \multirow[b]{2}{*}{$\mathrm{R}_{4}$} & \multicolumn{3}{|c|}{$\begin{array}{l}\text { antimalarial activity } \\
\left(\mathrm{IC}_{50} \text { in } \mathrm{nM}\right)^{a}\end{array}$} & \multirow[b]{2}{*}{ cytotoxicity $\left(\mathrm{IC}_{50} \text { in } \mathrm{nM}\right)^{a}$ HepG2 } & \multirow[b]{2}{*}{$\mathrm{SI}^{b}(\mathrm{D} 6)$} & \multirow[b]{2}{*}{$\operatorname{cLog} \mathrm{P}^{c}$} \\
\hline & & & & & D6 & $\mathrm{Dd} 2$ & $7 \mathrm{G} 8$ & & & \\
\hline 85 & $\mathrm{H}$ & $\mathrm{OMe}$ & $\mathrm{H}$ & & 6.1 & 4.8 & 5.5 & $>250000$ & $>40983$ & 4.8 \\
\hline 86 & $\mathrm{Me}$ & $\mathrm{OMe}$ & $\mathrm{H}$ & & 2250 & $>2500$ & $>2500$ & $\mathrm{nt}^{d}$ & & 5.1 \\
\hline 87 & $\mathrm{Me}$ & $\mathrm{OMe}$ & $\mathrm{Me}$ & & $>2500$ & $>2500$ & $>2500$ & nt & & 5.3 \\
\hline 88 & $\mathrm{H}$ & 4- $\mathrm{ClC}_{6} \mathrm{H}_{4}$ & $\mathrm{H}$ & & $>2500$ & $>2500$ & $>2500$ & nt & & 7.7 \\
\hline 89 & $n-\mathrm{C}_{11} \mathrm{H}_{23}$ & $\mathrm{H}$ & $\mathrm{H}$ & $\mathrm{H}$ & $>2500$ & $>2500$ & $>2500$ & $\mathrm{nt}$ & & 5.2 \\
\hline 90 & $n-\mathrm{C}_{11} \mathrm{H}_{23}$ & $\mathrm{H}$ & Et & $\mathrm{H}$ & 101 & 66 & 51 & 18939 & 187 & 5.7 \\
\hline 91 & $n-\mathrm{C}_{11} \mathrm{H}_{23}$ & $\mathrm{H}$ & $\mathrm{H}$ & $i-\operatorname{Pr}$ & 1586 & 1500 & $>2500$ & nt & & 6.3 \\
\hline 92 & $n-\mathrm{C}_{11} \mathrm{H}_{23}$ & $\mathrm{H}$ & $\mathrm{H}$ & $t$-Bu & $>2500$ & $>2500$ & $>2500$ & nt & & 6.7 \\
\hline 93 & $n-\mathrm{C}_{11} \mathrm{H}_{23}$ & $\mathrm{H}$ & Et & $\mathrm{Cl}$ & $>2500$ & $>2500$ & $>2500$ & $\mathrm{nt}$ & & 5.8 \\
\hline 94 & $n-\mathrm{C}_{11} \mathrm{H}_{23}$ & $\mathrm{H}$ & $\mathrm{Me}$ & $\mathrm{Et}$ & 162 & 190 & 145 & 62000 & 383 & 6.1 \\
\hline 95 & $\mathrm{n}-\mathrm{C}_{8} \mathrm{H}_{17}$ & $\mathrm{H}$ & $\mathrm{Me}$ & Et & 127 & 216 & 132 & 71000 & 559 & 4.8 \\
\hline 96 & $\mathrm{H}$ & $n-\mathrm{C}_{8} \mathrm{H}_{17}$ & $\mathrm{Me}$ & Et & 41 & 53 & 61 & 57200 & 1395 & 4.9 \\
\hline 97 & $n-\mathrm{C}_{7} \mathrm{H}_{15}$ & 4- $-\mathrm{FC}_{6} \mathrm{H}_{4} \mathrm{CH}_{2}$ & $\mathrm{Me}$ & Et & 6.5 & 7.0 & 5.9 & 82024 & 12619 & 6.7 \\
\hline 98 & 4- $\mathrm{ClC}_{6} \mathrm{H}_{4} \mathrm{CH}_{2}$ & 4- $\mathrm{ClC}_{6} \mathrm{H}_{4} \mathrm{CH}_{2}$ & $\mathrm{Me}$ & $\mathrm{Et}$ & 28 & 42 & 42 & 30600 & 1093 & 6.7 \\
\hline $1 a$ & & & & & 7.2 & 7.5 & 7.0 & nt & & 4.2 \\
\hline CQ & & & & & 13 & 115 & 130 & nt & & 3.7 \\
\hline MQ & & & & & nt & nt & nt & 21800 & & 5.3 \\
\hline
\end{tabular}

${ }^{a} \mathrm{IC}_{50}$ values are the average of at least three determinations, each carried out in triplicate $( \pm 10 \%)$. In order to compare results run on different days and with different batches of each stain, CQ was run as a positive control. All results obtained were "normalized" to the CQ values of $13 \mathrm{nM}$ for D6, $115 \mathrm{nM}$ for $\mathrm{Dd} 2$, and $130 \mathrm{nM}$ for $7 \mathrm{G} 8 .{ }^{b} \mathrm{SI}$ (selectivity index) $=\mathrm{IC}_{50}$ (cytotoxicity)/IC $\mathrm{I}_{50}(\mathrm{D} 6) .{ }^{c} \mathrm{cLogP}$ values were calculated using ChemBioDraw Ultra software (version 14$){ }^{d}{ }^{n}$ t $=$ not tested.

of ring-C/n-alkylamines on activity, we synthesized another set of TAs 103-109 (Table 2). Of these cycloalkylated TAs, analogues 108 and 109, which have the cyclooctylamine and 1 -adamantylamine moieties, respectively, were the most potent antimalarial candidates $\left(108 \mathrm{IC}_{50}<7.1 \mathrm{nM}\right.$ and $109 \mathrm{IC}_{50}<3.8 \mathrm{nM}$ against all tested Pf strains; see Table 2) with good selectivity, and these results are more comparable to the potent PG 85 $\left(\mathrm{IC}_{50}<6.1 \mathrm{nM}\right)$ and the natural PG 1a $\left(\mathrm{IC}_{50}<7.5 \mathrm{nM}\right)$. These results clearly demonstrated that the elongation of the cycloalkyl ring size (from cyclopropyl, 103, $\mathrm{IC}_{50}=2500 \mathrm{nM}$ to 1-adamantyl, $109, \mathrm{IC}_{50}<3.1 \mathrm{nM}$ ) led to an increase in activity (Table 2 and Figure 5). The greatest loss of potency $\left(\mathrm{IC}_{50}>2500 \mathrm{nM}\right)$ was observed in 110, in which ring-C is replaced by piperidine moiety, suggesting that the free $\mathrm{NH}$ is required for the potent antimalarial activity. Replacement of cyclohexyl moiety with benzylpiperidine as with 111 led to slightly reduced potency $\left(106 \mathrm{IC}_{50}=49 \mathrm{nM}\right.$ versus $111 \mathrm{IC}_{50}=$ $127 \mathrm{nM}$ against D6). The analogue 112, which contain a 4-chloroaniline in the place of ring-C showed the moderate activity (Table 2). These results unequivocally demonstrate that the ring-C of PGs can be replaced by alkylamines, providing the novel TAs with retained and/or enhanced antimalarial and cytotoxic properties.

To investigate the importance of the OMe group on ring- $\mathrm{B}$ of TAs, another set of TAs 113-119, in which the OMe group is replaced by 4-chlorophenyl moiety, was generated and examined for their in vitro antimalarial activity (Table 2). In vitro analysis of the activity of these compounds 113-119 against $P f$, demonstrated activity $\left(\mathrm{IC}_{50}>250 \mathrm{nM}\right)$ significantly diminished when compared to the corresponding OMe group containing TAs (100, 102, and 105-109). This work suggested that the bulky aromatic substitution at 4-position on the ring-B had an adverse effect on antimalarial activity. Interestingly the replacement of the OMe group with short alkyl substituents (methyl/ethyl) also reduced the potency of the compounds 120-122, 124, and $125\left(\mathrm{IC}_{50}>250 \mathrm{nM}\right.$ ) (Table 2). Conversely, the adamantyl analogues 123 and 126, in which the OMe group is replaced by methyl and ethyl groups on the ring-B, respectively, showed a substantially higher potency against D6 strain $\left(109 \mathrm{IC}_{50}=3.1 \mathrm{nM}\right.$ versus $123 \mathrm{IC}_{50}=1.3 \mathrm{nM}, 126$ $\left.\mathrm{IC}_{50}=2.5 \mathrm{nM}\right)$ with great selectivity. Complete removal of the OMe group on ring-B as with the analogues 127-129 resulted in the total loss of activity $\left(127,128, \mathrm{IC}_{50}>2500 \mathrm{nM}\right.$ vs 107 $\mathrm{IC}_{50}=23 \mathrm{nM}, 108 \mathrm{IC}_{50}=4.8 \mathrm{nM}$, and $129 \mathrm{IC}_{50}=341 \mathrm{nM}$ vs $109 \mathrm{IC}_{50}=3.1 \mathrm{nM}, 123 \mathrm{IC}_{50}=1.3 \mathrm{nM}, 126 \mathrm{IC}_{50}=2.5 \mathrm{nM}$ against D6). Together, these results again demonstrate that the substituents at 4-position on the ring-B have an important role in potent antimalarial activity, and the OMe group can be replaced by short alkyl substituents (methyl/ethyl) when 1 -adamantylamine exists in the place of ring-C.

In Vitro Antimalarial Activity of 3-Substituted B-Ring Functionalized TAs (130-141). Having established the substitution pattern at 4-position on the ring-B and the terminal alkylamines (cycloheptyl-, cyclooctyl-, and 1-adamantylamines) as optimal, we then examined the effects of substitution pattern at 3-position, where the 4-position is vacant on the ring-B of 
Table 2. In Vitro Antimalarial Activity and Cytotoxicity of 4-Substituted B-Ring Functionalized TAs (99-129)

\begin{tabular}{|c|c|c|c|c|c|c|c|c|}
\hline \multirow[b]{2}{*}{ compd } & \multirow[b]{2}{*}{$\mathrm{R}_{1}$} & \multirow[b]{2}{*}{$\mathrm{R}_{2}$} & \multicolumn{3}{|c|}{$\begin{array}{l}\text { antimalarial activity } \\
\left(\mathrm{IC}_{50} \text { in } \mathrm{nM}\right)^{\mathrm{a}}\end{array}$} & \multirow[b]{2}{*}{$\begin{array}{c}\text { cytotoxicity } \\
\left(\mathrm{IC}_{50} \text { in } \mathrm{nM}\right)^{\mathrm{a}} \mathrm{HepG} 2\end{array}$} & \multirow[b]{2}{*}{$\begin{array}{l}\mathrm{SI}^{\mathrm{b}} \\
\text { (D6) }\end{array}$} & \multirow[b]{2}{*}{$\operatorname{cLog} \mathrm{P}^{\circ}$} \\
\hline & & & D6 & $\mathrm{Dd} 2$ & 7G8 & & & \\
\hline 99 & $\mathrm{OMe}$ & $\mathrm{n}-\mathrm{C}_{4} \mathrm{H}_{9}$ & 210 & 159 & 74.6 & 23000 & 109 & 0.08 \\
\hline 100 & $\mathrm{OMe}$ & $\mathrm{n}-\mathrm{C}_{6} \mathrm{H}_{13}$ & 34 & 37 & 25 & 26700 & 785 & 0.9 \\
\hline 101 & $\mathrm{OMe}$ & $\mathrm{n}-\mathrm{C}_{8} \mathrm{H}_{17}$ & 345 & 177 & 69 & $\mathrm{nt}^{\mathrm{d}}$ & - & 1.7 \\
\hline 102 & $\mathrm{OMe}$ & $\mathrm{n}-\mathrm{C}_{11} \mathrm{H}_{23}$ & 55 & 53 & 23 & 9800 & 178 & 3.0 \\
\hline 103 & $\mathrm{OMe}$ & $x^{x}$ & 2400 & 2500 & 946 & $\mathrm{nt}$ & - & -0.9 \\
\hline 104 & $\mathrm{OMe}$ & & 591 & 497 & 156 & nt & - & -0.4 \\
\hline 105 & $\mathrm{OMe}$ & & 68 & 84 & 45 & 30500 & 448 & -0.03 \\
\hline 106 & $\mathrm{OMe}$ & & 49 & 71 & 30 & 15000 & 306 & 0.4 \\
\hline 107 & $\mathrm{OMe}$ & & 23 & 34 & 15 & 10100 & 439 & 0.8 \\
\hline 108 & $\mathrm{OMe}$ & & 4.8 & 7.1 & 7.5 & 9700 & 2021 & 1.2 \\
\hline 109 & $\mathrm{OMe}$ & & 3.1 & 2.6 & 3.8 & 3300 & 1064 & 0.7 \\
\hline 110 & $\mathrm{OMe}$ & 运] & $>2500$ & $>2500$ & $>2500$ & nt & - & -0.05 \\
\hline 111 & $\mathrm{OMe}$ & & 127 & 244 & 207 & $>250000$ & $>1968$ & 0.5 \\
\hline 112 & $\mathrm{OMe}$ & $4-\mathrm{ClC}_{6} \mathrm{H}_{4}$ & 255 & 368 & 314 & $\mathrm{nt}$ & - & 1.1 \\
\hline 113 & 4- $\mathrm{ClC}_{6} \mathrm{H}_{4}$ & $\mathrm{n}-\mathrm{C}_{6} \mathrm{H}_{13}$ & 1129 & $>2500$ & 564 & $\mathrm{nt}$ & - & 3.8 \\
\hline 114 & $4-\mathrm{ClC}_{6} \mathrm{H}_{4}$ & $\mathrm{n}-\mathrm{C}_{11} \mathrm{H}_{23}$ & 664 & $>2500$ & 663 & nt & - & 5.9 \\
\hline 115 & 4- $\mathrm{ClC}_{6} \mathrm{H}_{4}$ & & 1218 & $>2500$ & 510 & nt & - & 2.9 \\
\hline 116 & 4- $\mathrm{ClC}_{6} \mathrm{H}_{4}$ & & 1025 & $>2500$ & 415 & $\mathrm{nt}$ & - & 3.3 \\
\hline 117 & 4- $\mathrm{ClC}_{6} \mathrm{H}_{4}$ & & 963 & 1250 & 348 & nt & - & 3.7 \\
\hline 118 & $4-\mathrm{ClC}_{6} \mathrm{H}_{4}$ & & 832 & 1135 & 316 & nt & - & 4.1 \\
\hline 119 & 4- $\mathrm{ClC}_{6} \mathrm{H}_{4}$ & & $>250$ & $>250$ & 126 & $\mathrm{nt}$ & - & 3.6 \\
\hline 120 & $\mathrm{Me}$ & $\mathrm{n}-\mathrm{C}_{11} \mathrm{H}_{23}$ & 1167 & 1469 & 515 & $\mathrm{nt}$ & - & 4.2 \\
\hline 121 & $\mathrm{Me}$ & & $>250$ & $>250$ & $>250$ & $\mathrm{nt}$ & - & 2.0 \\
\hline 122 & $\mathrm{Me}$ & & $>250$ & $>250$ & $>250$ & $\mathrm{nt}$ & - & 2.4 \\
\hline 123 & $\mathrm{Me}$ & & 1.3 & 15 & 4.3 & 6900 & 5308 & 1.8 \\
\hline 124 & $\mathrm{Et}$ & & $>250$ & $>250$ & $>250$ & $\mathrm{nt}$ & - & 2.4 \\
\hline 125 & Et & & $>250$ & $>250$ & $>250$ & $\mathrm{nt}$ & - & 2.8 \\
\hline 126 & Et & & 2.5 & 16 & 7.7 & 6100 & 2440 & 2.2 \\
\hline 127 & $\mathrm{H}$ & & $>2500$ & $>2500$ & $>2500$ & $\mathrm{nt}$ & - & 1.8 \\
\hline 128 & $\mathrm{H}$ & & $>2500$ & $>2500$ & $>2500$ & $\mathrm{nt}$ & - & 2.2 \\
\hline 129 & $\mathrm{H}$ & 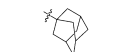 & 341 & 295 & 235 & 70000 & 205 & 1.6 \\
\hline CQ & & & 13 & 115 & 130 & $\mathrm{nt}$ & - & 3.7 \\
\hline MQ & & & $\mathrm{nt}$ & $\mathrm{nt}$ & nt & 21800 & - & 5.3 \\
\hline
\end{tabular}

${ }^{a} \mathrm{IC}_{50}$ values are the average of at least three determinations, each carried out in triplicate $( \pm 10 \%)$. In order to compare results run on different days and with different batches of each stain, CQ was run as a positive control. All results obtained were "normalized" to the CQ values of $13 \mathrm{nM}$ for D6, $115 \mathrm{nM}$ for Dd2, and $130 \mathrm{nM}$ for $7 \mathrm{G} 8 .{ }^{b} \mathrm{SI}$ (selectivity index) $=\mathrm{IC}_{50}$ (cytotoxicity)/IC $\mathrm{I}_{50}$ (D6). ${ }^{c} \mathrm{cLogP}$ values were calculated using ChemBioDraw Ultra software (version 14), ${ }^{d} \mathrm{nt}=$ not tested.

the TAs (Table 3). To that end, we generated a series of novel TAs 130-141, in which the 3-position on the ring-B is occupied with alkyl groups and screened for their antimalarial activity against $P f$ strains (Table 3 ). The greatest loss of potency 


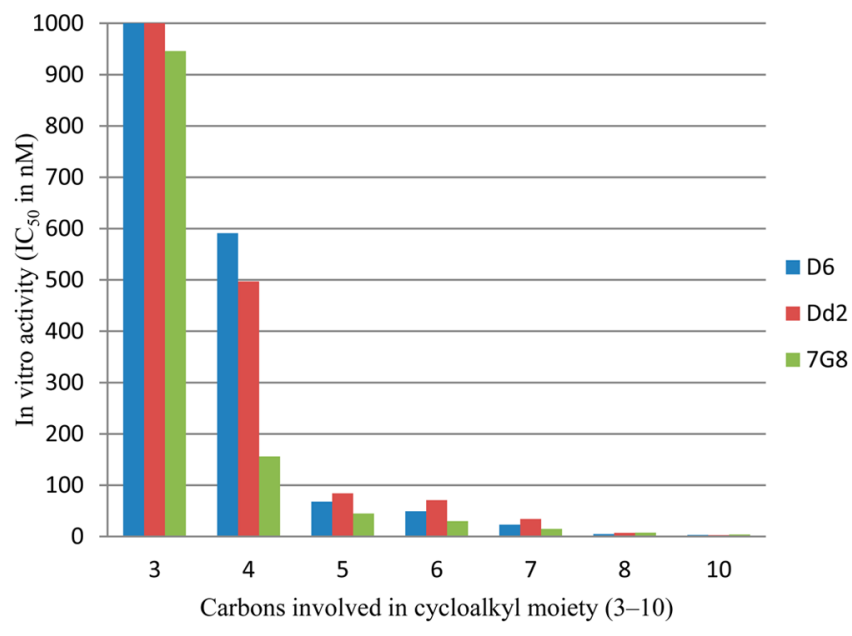

Figure 5. SAR of TAs (103-109) containing various cycloalkyl groups and in vitro antimalarial activity against $P f$ strains D6, Dd2, and 7G8.

was observed when the short alkyl (methyl/ethyl) groups move from 4-position (121-126, Table 2) to the 3-position (130141, Table 3). Moreover, the adamantyl analogues 132 and 135 showed a significant decline in activity (132 $\mathrm{IC}_{50}=$ $106 \mathrm{nM}$ vs $123 \mathrm{IC}_{50}=1.3 \mathrm{nM}$, and $135 \mathrm{IC}_{50}=117 \mathrm{nM}$ vs $126 \mathrm{IC}_{50}=2.5 \mathrm{nM}$ against D6), and the analogue 141 had an almost total loss of activity $\left(\mathrm{IC}_{50}>2500 \mathrm{nM}\right)$. The one exception is the adamantyl analogue 138, containing an isopropyl group at 3 -position on the ring-B, which showed the better potency $\left(\mathrm{IC}_{50}<30 \mathrm{nM}\right)$ against all tested $P f$ strains with good selectivity. These results show that generally alkyl substitutions at 3-position versus the 4-position adversely affect the potency irrespective of the terminal alkylamines.

In Vitro Antimalarial Activity of 3,4-Disubstituted B-Ring Functionalized TAs (142-165). Exploration of the SARs around the ring-B of TAs indicated that the substitutions at 4-position were greatly favored compared to the 3-position (Tables 2 and 3). This finding is exemplified by the poor activity of the 3-substituted analogues (130-141) with the exception of 138. We next investigated whether substitutions at both the 3- and 4-positions are tolerated. We synthesized a series of 3,4-disubstituted B-ring functionalized TAs 142-149, which have 3-ethyl and 4-methyl groups on the ring-B (Table 4). Of these 3,4-disubstituted TAs, analogues 142-144, 148, and 149 with an $n$-alkyl, cyclopropyl, benzylpiperidine, and morpholine moieties, respectively, showed diminished activity (Table 4). Conversely, the analogues 145 and 146, which have cycloheptyl and cyclooctyl moieties, respectively, showed the highest potencies (Table 4) compared with those of the corresponding 3- and 4-monoalkyl substituted analogues (see Tables 2 and 3). Significantly, the adamantyl analogue 147 showed comparable

Table 3. In Vitro Antimalarial Activity and Cytotoxicity of 3-Substituted B-Ring Functionalized TAs (130-141)

\begin{tabular}{|c|c|c|c|c|c|c|c|c|}
\hline \multirow[b]{2}{*}{ compd } & \multirow[b]{2}{*}{$\mathrm{R}_{1}$} & \multirow[b]{2}{*}{$\mathrm{R}_{2}$} & & $\begin{array}{l}\text { halarial a } \\
\mathrm{C}_{50} \text { in } \mathrm{nN}\end{array}$ & $\mathrm{H}_{\mathrm{N}}$ & \multirow[b]{2}{*}{$\begin{array}{c}\text { cytotoxicity } \\
\left(\mathrm{IC}_{50} \text { in } \mathrm{nM}\right)^{\mathrm{a}} \mathrm{HepG} 2\end{array}$} & \multirow[b]{2}{*}{$\begin{array}{c}\mathrm{SI}^{\mathrm{b}} \\
\text { (D6) }\end{array}$} & \multirow[b]{2}{*}{$\operatorname{cLog} \mathrm{P}^{\mathrm{c}}$} \\
\hline & & & D6 & $\mathrm{Dd} 2$ & $7 \mathrm{G} 8$ & & & \\
\hline 130 & $\mathrm{Me}$ & & 2107 & $>2500$ & 2147 & $n \mathrm{t}^{\mathrm{d}}$ & - & 2.1 \\
\hline 131 & $\mathrm{Me}$ & $x$ & 1376 & $>250$ & 1778 & $\mathrm{nt}$ & - & 2.5 \\
\hline 132 & $\mathrm{Me}$ & t & 106 & 170 & 95 & 30000 & 283 & 2.0 \\
\hline 133 & Et & 4 & 1305 & 523 & 1456 & $\mathrm{nt}$ & - & 2.5 \\
\hline 134 & Et & & 1276 & $>250$ & 1326 & $\mathrm{nt}$ & - & 3.0 \\
\hline 135 & Et & & 117 & 45 & 90 & 15200 & 130 & 2.4 \\
\hline 136 & $i-\operatorname{Pr}$ & $\mathrm{t}$ & $>2500$ & 1968 & 1980 & $\mathrm{nt}$ & - & 2.9 \\
\hline 137 & $i-\operatorname{Pr}$ & & 1079 & 665 & 1480 & $\mathrm{nt}$ & - & 3.3 \\
\hline 138 & $i-\operatorname{Pr}$ & & 26 & 20 & 31 & 18500 & 711 & 2.7 \\
\hline 139 & $\mathrm{t}-\mathrm{Bu}$ & 4 & $>2500$ & $>2500$ & $>2500$ & $\mathrm{nt}$ & - & 3.3 \\
\hline 140 & $\mathrm{t}-\mathrm{Bu}$ & xy & $>2500$ & $>2500$ & $>2500$ & $\mathrm{nt}$ & - & 3.8 \\
\hline 141 & $\mathrm{t}-\mathrm{Bu}$ & & $>2500$ & $>2500$ & $>2500$ & $\mathrm{nt}$ & - & 3.2 \\
\hline CQ & & & 13 & 115 & 130 & $\mathrm{nt}$ & - & 3.7 \\
\hline MQ & & & $\mathrm{nt}$ & $\mathrm{nt}$ & $\mathrm{nt}$ & 21800 & - & 5.3 \\
\hline
\end{tabular}

${ }^{a} \mathrm{IC}_{50}$ values are the average of at least three determinations, each carried out in triplicate $( \pm 10 \%)$. In order to compare results run on different days and with different batches of each stain, CQ was run as a positive control. All results obtained were "normalized" to the CQ values of $13 \mathrm{nM}$ for D6, $115 \mathrm{nM}$ for Dd2, and $130 \mathrm{nM}$ for $7 \mathrm{G} 8 .{ }^{b} \mathrm{SI}$ (selectivity index) $=\mathrm{IC}_{50}$ (cytotoxicity)/IC ${ }_{50}(\mathrm{D} 6) .{ }^{c} \mathrm{cLogP}$ values were calculated using ChemBioDraw Ultra software (version 14$) .{ }^{d} \mathrm{nt}=$ not tested. 
Table 4. In Vitro Antimalarial Activity and Cytotoxicity of 3,4-Disubstituted B-Ring Functionalized TAs (142-165)

\begin{tabular}{|c|c|c|c|c|c|c|c|c|c|}
\hline \multirow[b]{2}{*}{ compd } & \multirow[b]{2}{*}{$\mathrm{R}_{1}$} & \multirow[b]{2}{*}{$\mathrm{R}_{2}$} & \multirow[b]{2}{*}{$\mathrm{R}_{3}$} & \multicolumn{3}{|c|}{ antimalarial activity } & \multirow[b]{2}{*}{$\begin{array}{c}\text { cytotoxicity } \\
\left(\mathrm{IC}_{50} \text { in } \mathrm{nM}\right)^{\mathrm{a}} \text { HepG2 }\end{array}$} & \multirow[b]{2}{*}{$\begin{array}{c}\mathrm{SI}^{\mathrm{b}} \\
\text { (D6) }\end{array}$} & \multirow[b]{2}{*}{$\operatorname{cLog} \mathrm{P}^{\mathrm{c}}$} \\
\hline & & & & D6 & $\mathrm{Dd} 2$ & $7 \mathrm{G} 8$ & & & \\
\hline 142 & Et & $\mathrm{Me}$ & $\mathrm{n}-\mathrm{C}_{4} \mathrm{H}_{9}$ & 883 & 680 & 260 & $n t^{\mathrm{d}}$ & - & 2.0 \\
\hline 143 & Et & $\mathrm{Me}$ & $\mathrm{n}-\mathrm{C}_{8} \mathrm{H}_{17}$ & 1166 & 633 & 244 & $\mathrm{nt}$ & - & 3.7 \\
\hline 144 & Et & $\mathrm{Me}$ & & $>2500$ & 2047 & 2500 & $\mathrm{nt}$ & - & 1.1 \\
\hline 145 & Et & $\mathrm{Me}$ & C & 62 & 55 & 60 & 19200 & 310 & 2.7 \\
\hline 146 & Et & $\mathrm{Me}$ & & 56 & 60 & 75 & 18900 & 337 & 3.1 \\
\hline 147 & Et & $\mathrm{Me}$ & 8 & 5.5 & 4.3 & 3.6 & 3300 & 600 & 2.6 \\
\hline 148 & Et & $\mathrm{Me}$ & $x^{2}$ & $>2500$ & 1576 & 855 & $\mathrm{nt}$ & - & 2.4 \\
\hline 149 & Et & $\mathrm{Me}$ & & $>2500$ & $>2500$ & $>2500$ & $\mathrm{nt}$ & - & 0.3 \\
\hline 150 & $\mathrm{Me}$ & Et & & 150 & 200 & 117 & 15800 & 105 & 2.7 \\
\hline 151 & $\mathrm{Me}$ & Et & & 111 & 201 & 128 & 23900 & 215 & 3.1 \\
\hline 152 & $\mathrm{Me}$ & Et & & 19 & 14 & 14 & 4500 & 237 & 2.6 \\
\hline 153 & $\mathrm{Me}$ & $\mathrm{Me}$ & 4 & 60 & 38 & 47 & 21300 & 355 & 2.3 \\
\hline 154 & $\mathrm{Me}$ & $\mathrm{Me}$ & & 56 & 31 & 45 & 18100 & 323 & 2.7 \\
\hline 155 & $\mathrm{Me}$ & $\mathrm{Me}$ & & 2.4 & 1.7 & 1.5 & 6400 & 2667 & 2.2 \\
\hline 156 & Et & Et & & 54 & 30 & 88 & 16900 & 313 & 3.1 \\
\hline 157 & $\mathrm{Et}$ & Et & & 39 & 26 & 58 & 13000 & 333 & 3.6 \\
\hline 158 & $\mathrm{Et}$ & Et & & 1.6 & 1.0 & 2.5 & 3900 & 2437 & 3.0 \\
\hline 159 & $-\left(\mathrm{CH}_{2}\right.$ & $\left.\mathrm{H}_{2}\right)_{2}-$ & & 35 & 39 & 23 & 6200 & 177 & 2.6 \\
\hline 160 & $-\left(\mathrm{CH}_{2}\right.$ & $\left.\mathrm{H}_{2}\right)_{2-}$ & & 32 & 37 & 22 & 4600 & 144 & 3.1 \\
\hline 161 & $-\left(\mathrm{CH}_{2}\right.$ & $\left.\mathrm{H}_{2}\right)_{2}-$ & & 6.1 & 7.5 & 2.8 & 2700 & 442 & 2.5 \\
\hline 162 & $\mathrm{Cl}$ & Et & $\mathrm{t}-\mathrm{Bu}$ & 1217 & $>2500$ & $>2500$ & $\mathrm{nt}$ & - & 1.7 \\
\hline 163 & $\mathrm{Cl}$ & Et & & $>2500$ & $>2500$ & $>2500$ & $\mathrm{nt}$ & - & 2.4 \\
\hline 164 & $\mathrm{Cl}$ & Et & t & $>2500$ & $>2500$ & $>2500$ & $\mathrm{nt}$ & - & 2.8 \\
\hline 165 & $\mathrm{Cl}$ & Et & 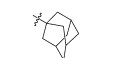 & 2300 & $>2500$ & 2250 & $\mathrm{nt}$ & - & 2.3 \\
\hline CQ & & & & 13 & 115 & 130 & $\mathrm{nt}$ & - & 3.7 \\
\hline MQ & & & & $\mathrm{nt}$ & $\mathrm{nt}$ & $\mathrm{nt}$ & 21800 & - & 5.3 \\
\hline
\end{tabular}

${ }^{a} \mathrm{IC}_{50}$ values are the average of at least three determinations, each carried out in triplicate $( \pm 10 \%)$. In order to compare results run on different days and with different batches of each stain, CQ was run as a positive control. All results obtained were "normalized" to the CQ values of $13 \mathrm{nM}$ for D6, $115 \mathrm{nM}$ for $\mathrm{Dd} 2$, and $130 \mathrm{nM}$ for $7 \mathrm{G} 8 .{ }^{b} \mathrm{SI}$ (selectivity index) $=\mathrm{IC}_{50}$ (cytotoxicity)/IC ${ }_{50}(\mathrm{D} 6) .{ }^{c} \mathrm{cLogP}$ values were calculated using ChemBioDraw Ultra software (version 14$).{ }^{d}$ nt $=$ not tested.

potency to that of the corresponding 4-alkyl/methoxy substituted analogues $\left(147 \mathrm{IC}_{50}=5.5 \mathrm{nM}\right.$ versus $109 \mathrm{IC}_{50}=3.1 \mathrm{nM}$, $123 \mathrm{IC}_{50}=1.3 \mathrm{nM}, 126 \mathrm{IC}_{50}=2.5 \mathrm{nM}$ against D6), and this potency is 5- to 20-fold greater than the corresponding 3-alkyl substituted analogues $\left(147 \mathrm{IC}_{50}=5.5 \mathrm{nM}\right.$ versus $132 \mathrm{IC}_{50}=$ $106 \mathrm{nM}, 135 \mathrm{IC}_{50}=117 \mathrm{nM}, 138 \mathrm{IC}_{50}=26 \mathrm{nM}$ against D6). Interchange of the methyl and ethyl groups between 3- and 4-positions on the ring-B as in 150-152 resulted in a $\sim 2$-fold decrease in potency $\left(\mathrm{IC}_{50}\right.$ of 150-152 vs $\mathrm{IC}_{50}$ of $145-147$ ). We were encouraged that the short alkyl substitutions at both the 3- and 4-positions on the ring-B were well tolerated with comparable and/or enhanced activities. This allowed for a variety of different analogues to be synthesized with representative examples (153-165, Table 4). The analogues 153, $154,156,157,159$, and 160, which contain the same alkyl groups (methyl/ethyl/- $\left(\mathrm{CH}_{2}-\mathrm{CH}_{2}\right)_{2}$-) at both 3- and 4-positions on the ring- $\mathrm{B}$, and cycloheptyl/cyclooctylamines in the place of ring- $C$ were shown to have comparable and/or greater potency to the dissimilar alkyl groups at both 3- and 4-positions containing TAs. Significantly, the adamantyl analogues 155 $\left(\mathrm{IC}_{50}<2.4 \mathrm{nM}\right), 158\left(\mathrm{IC}_{50}<2.5 \mathrm{nM}\right)$, and $161\left(\mathrm{IC}_{50}<7.5 \mathrm{nM}\right)$ showed enhanced (2- to 8-fold) or comparable potency against all tested $P f$ strains when compared to $147\left(\mathrm{IC}_{50}<5.5 \mathrm{nM}\right)$ and $152\left(\mathrm{IC}_{50}<19 \mathrm{nM}\right)$. The biggest potency loss occurred 
Table 5. In Vitro Antimalarial Activity and Cytotoxicity of A- and B-Ring Functionalized TAs (166-187)<smiles>[R]C1=N/C(=C\NC23CC4CC(CC(C4)C2)C3)C([R])=C1[R]</smiles>

\begin{tabular}{|c|c|c|c|c|c|c|c|c|c|}
\hline \multirow[b]{2}{*}{ compd } & \multirow[b]{2}{*}{$\mathrm{R}_{1}$} & \multirow[b]{2}{*}{$\mathrm{R}_{2}$} & \multirow[b]{2}{*}{$\mathrm{R}_{3}$} & \multicolumn{3}{|c|}{$\begin{array}{l}\text { antimalarial activity } \\
\left(\mathrm{IC}_{50} \text { in nM) }\right)^{\mathrm{a}}\end{array}$} & \multirow[b]{2}{*}{$\begin{array}{c}\text { cytotoxicity } \\
\left(\mathrm{IC}_{50} \text { in nM) }\right)^{\mathrm{a}} \\
\text { HepG2 }\end{array}$} & \multirow[b]{2}{*}{$\begin{array}{l}\mathrm{SI}^{\mathrm{b}} \\
\text { (D6) }\end{array}$} & \multirow[b]{2}{*}{$\operatorname{cLog} \mathrm{P}$} \\
\hline & & & & D6 & $\mathrm{Dd} 2$ & $7 \mathrm{G} 8$ & & & \\
\hline 166 & $\mathrm{H}$ & (1) $\{-$ & $\mathrm{H}$ & $>2500$ & $>2500$ & $>2500$ & $\mathrm{nt}^{\mathrm{d}}$ & - & 1.3 \\
\hline 167 & $\mathrm{H}$ & 111) $-\xi$ & $\mathrm{Me}$ & $>2500$ & $>2500$ & $>2500$ & nt & - & 1.4 \\
\hline 168 & $\mathrm{H}$ & 11) $\}$ & Et & $>2500$ & 1233 & $>2500$ & $\mathrm{nt}$ & - & 1.9 \\
\hline 169 & $\mathrm{Me}$ & 1) $\}$ & $\mathrm{Me}$ & 1418 & 1736 & 2005 & nt & - & 1.6 \\
\hline 170 & & $\mathrm{Me}$ & $\mathrm{Me}$ & 250 & 328 & 215 & nt & - & 2.1 \\
\hline 171 & & $\mathrm{Me}$ & $\mathrm{Me}$ & 647 & 1716 & 415 & nt & - & 2.2 \\
\hline 172 & & Me & $\mathrm{Me}$ & 415 & 273 & 2282 & nt & - & 3.6 \\
\hline 173 & & $\mathrm{Me}$ & $\mathrm{Me}$ & 1141 & 831 & $>2500$ & nt & - & 3.6 \\
\hline 174 & & $\mathrm{Me}$ & $\mathrm{Me}$ & 318 & 388 & 161 & nt & - & 3.2 \\
\hline 175 & & $-(\mathrm{Cl}$ & $\left.\mathrm{I}_{2}\right)_{2}-$ & 1335 & 1103 & 946 & nt & - & 1.9 \\
\hline 176 & & $\mathrm{Me}$ & $\mathrm{Me}$ & $>2500$ & $>2500$ & $>2500$ & nt & - & 2.4 \\
\hline 177 & & $\mathrm{Me}$ & $\mathrm{Me}$ & 2.1 & 2.3 & 0.5 & 3600 & 1714 & 3.0 \\
\hline 178 & & $\mathrm{Me}$ & $\mathrm{Me}$ & $<2.5$ & $<2.5$ & $<2.5$ & 1235 & $>494$ & 3.7 \\
\hline 179 & & $\mathrm{Me}$ & $\mathrm{Me}$ & 4.8 & 4.0 & 2.8 & 3825 & 797 & 3.1 \\
\hline 180 & & $\mathrm{Me}$ & $\mathrm{Me}$ & 27 & 75 & 12 & 17920 & 664 & 3.0 \\
\hline 181 & & $\mathrm{Me}$ & $\mathrm{Me}$ & 58 & 92 & 48 & 21323 & 368 & 3.9 \\
\hline 182 & $\mathrm{H}$ & $\mathrm{H}$ & $\mathrm{H}$ & $>2500$ & $>2500$ & $>2500$ & $\mathrm{nt}$ & - & 1.2 \\
\hline 183 & $\mathrm{Me}$ & $\mathrm{H}$ & $\mathrm{H}$ & 2100 & 1682 & $>2500$ & nt & - & 1.3 \\
\hline 184 & Me & $\mathrm{H}$ & $\mathrm{Me}$ & 315 & 268 & 399 & $\mathrm{nt}$ & - & 1.5 \\
\hline 185 & Me & Et & $\mathrm{Me}$ & 33 & 80 & 33 & 29900 & 906 & 2.2 \\
\hline 186 & $\mathrm{Me}$ & $-(\mathrm{CH}$ & $\left.\mathrm{I}_{2}\right)_{2}-$ & 61 & 64 & 60 & 5430 & 89 & 2.2 \\
\hline 187 & & Et & $\mathrm{Me}$ & $>2500$ & $>2500$ & $>2500$ & nt & - & 4.5 \\
\hline CQ & & & & 13 & 115 & 130 & $\mathrm{nt}$ & - & 3.7 \\
\hline MQ & & & & nt & nt & nt & 21000 & - & 5.3 \\
\hline
\end{tabular}

${ }^{a} \mathrm{IC}_{50}$ values are the average of at least three determinations, each carried out in triplicate $( \pm 10 \%)$. In order to compare results run on different days and with different batches of each stain, CQ was run as a positive control. All results obtained were "normalized" to the CQ values of $13 \mathrm{nM}$ for D6, $115 \mathrm{nM}$ for Dd2, and $130 \mathrm{nM}$ for $7 \mathrm{G} 8 .{ }^{b} \mathrm{SI}$ (selectivity index) $=\mathrm{IC}_{50}$ (cytotoxicity)/IC ${ }_{50}(\mathrm{D} 6) .{ }^{c} \mathrm{cLogP}$ values were calculated using ChemBioDraw Ultra software (version 14$){ }^{d}$ nt $=$ not tested.

$\left(\mathrm{IC}_{50}>2250 \mathrm{nM}\right)$ when we introduced a chlorine atom at 3-position on the ring- $\mathrm{B}$ as in 162-165 $\left(\mathrm{IC}_{50}\right.$ of $156-158$ vs 163-165, Table 4), and it is consistent with the observation that the chlorine atom (EWG) has an adverse effect at 3-position on the ring-B of PGs. Collectively, from the monoalkylated (Tables 2 and 3) and 3,4-dialkylated TAs (Table 4) the data clearly showed that the 3,4-disubstituted TAs containing cycloheptyl/cyclooctyl groups have significantly improved potency than the corresponding monoalkylated TAs (Tables 2 and 3), and these potencies were comparable to the corresponding OMe group containing analogues (Table 2). Notably, all the adamantyl analogues, which have short (alkyl/methoxy) groups at 4-position (Table 2) and dialkyl groups at 3/4- 

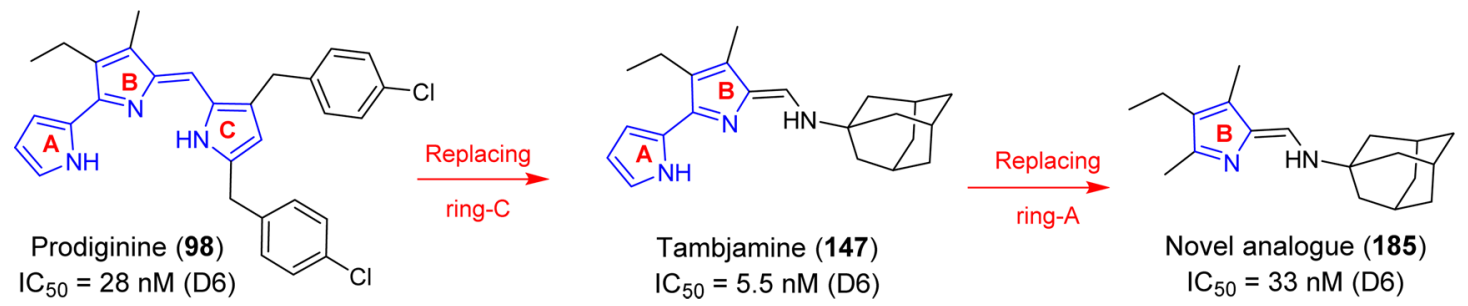

Figure 6. Structure pruning approach of the lead PG compounds (98).

Table 6. In Vitro Antimalarial Activity of TA-like Analogues (190, 191, and 194-196)

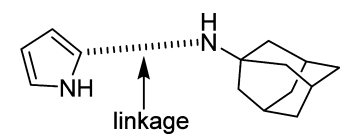

\begin{tabular}{|c|c|c|c|c|c|}
\hline \multirow[b]{2}{*}{ compd } & \multirow[b]{2}{*}{ linkage } & \multicolumn{3}{|c|}{$\begin{array}{r}\text { antimalarial activity } \\
\left(\mathrm{IC}_{50} \text { in } \mathrm{nM}\right)^{\mathrm{a}}\end{array}$} & \multirow[b]{2}{*}{$\operatorname{cLog} \mathrm{P}^{\mathrm{b}}$} \\
\hline & & D6 & $\mathrm{Dd} 2$ & 7G8 & \\
\hline 190 & & $>2500$ & $>2500$ & $>2500$ & 0.4 \\
\hline 191 & & $>2500$ & $>2500$ & $>2500$ & 1.6 \\
\hline 194 & & $>2500$ & $>2500$ & $>2500$ & 0.7 \\
\hline 195 & & $>2500$ & $>2500$ & $>2500$ & 0.6 \\
\hline 196 & & $>2500$ & $>2500$ & $>2500$ & 2.1 \\
\hline CQ & - & 13 & 115 & 130 & 3.7 \\
\hline
\end{tabular}

${ }^{a} \mathrm{IC}_{50}$ values are the average of at least three determinations, each carried out in triplicate $( \pm 10 \%)$. In order to compare results run on different days and with different batches of each stain, CQ was run as a positive control. All results obtained were "normalized" to the $\mathrm{CQ}$ values of $13 \mathrm{nM}$ for D6, $115 \mathrm{nM}$ for $\mathrm{Dd} 2$, and $130 \mathrm{nM}$ for 7G8. ${ }^{b}$ cLogP values were calculated using ChemBioDraw Ultra software (version 14).

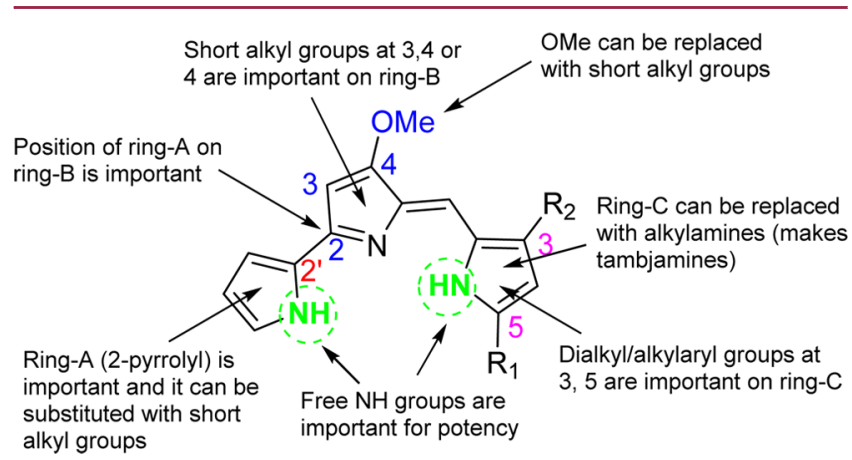

Figure 7. Summary of SAR analysis of PGs and TAs.

positions (Table 4) on ring-B, showed the greatest activity with good selectivity.

In Vitro Antimalarial Activity of A- and B-Ring Functionalized TAs (166-187). After establishing the substitutions pattern at 3 - and 4-positions on the ring-B of TAs, we investigated the importance of positioning of the ring-A at 2-position on the ring-B of TAs (Table 5) by keeping the 1-adamantylamine as an active pharmacophore for all analogues. The TAs 166-169, in which the ring-A (2-pyrrolyl moiety) is shifted from 2- to 3-position on the ring-B and are isomeric to 129, 123, 126, and 155 (Tables 2 and 4), respectively, were synthesized and tested against $P f$ strains (Table 5). It is noteworthy that the potency was significantly declined against all tested $P f$ strains after shifting the ring-A from 2- to 3-position $\left(166-168 \mathrm{IC}_{50}>2500 \mathrm{nM}\right.$ vs $123 \mathrm{IC}_{50}=1.3 \mathrm{nM}$, $126 \mathrm{IC}_{50}=2.5 \mathrm{nM}, 129 \mathrm{IC}_{50}=341 \mathrm{nM}$, and $169 \mathrm{IC}_{50}=1418$ $\mathrm{nM}$ vs $155 \mathrm{IC}_{50}<2.5 \mathrm{nM}$, against D6, Tables 2, 4, and 5). The importance of the location of nitrogen within ring-A was analyzed by moving from the $2^{\prime}$-position to the $3^{\prime}$-position (Figure 1 and Table 5), where compound $\mathbf{1 7 0}$ showed a roughly 100 -fold drop in activity $\left(170 \mathrm{IC}_{50}=250 \mathrm{nM}\right.$ vs 155 $\mathrm{IC}_{50}<2.5 \mathrm{nM}$, against D6, Tables 4 and 5). We also looked at the alternatives to the ring-A at 2 position of the ring-B. Replacement of the ring-A (2-pyrrolyl) by various 2-heteroaryl/ phenyl moieties (compounds 171-175) resulted in a decrease in antimalarial activity ( $\mathrm{IC}_{50}$ of $171-175$ vs 155 and 161). Notably, our previous SAR investigations revealed that the ring-A (2-pyrrolyl moiety) of PGs provides optimal activity, ${ }^{37,38}$ and the current results also suggest the importance of the ring-A of TAs for the potent activity. Alkylation (methylation) on the $\mathrm{NH}$ group of the ring-A as in $\mathbf{1 7 6}$ resulted in a large decrease in potency $\left(176 \mathrm{IC}_{50}>2500 \mathrm{nM}\right.$ vs $155 \mathrm{IC}_{50}<2.5 \mathrm{nM}$ ), suggesting that the pyrrole $\mathrm{NH}$ (ring-A) of the TAs is important for potent antimalarial activity. Conversely, the analogues 177-181, which contain C-alkyl moieties on the ring-A, retained the potency against all tested $P f$ strains, suggesting that the alkyl groups are well tolerated on the ring-A.

To further investigate the exact role of the ring-A of TAs on potency, a set of mixed alkylated analogues 182-186, in which the ring-A is completely removed from the core moiety of TAs, were examined. Complete removal of the substitutions on the ring-B dramatically reduced the potency of the compound $\mathbf{1 8 2}$ $\left(\mathrm{IC}_{50}>2500 \mathrm{nM}\right)$. Incorporation of the substitutions into the ring-B as in 183-186 (from mono- to trialkyl) resulted in a large increase in potency (Table 5), whereas the dimer 187 of the $\mathbf{1 8 5}$ showed the poorest activity. It is noteworthy that the analogues 185 and 186, which contain a monopyrrole with trialkyl substituents and an enamine moiety, showed the comparable potency to that of the corresponding bipyrrole TAs. These results demonstrated that the ring-A is not essential for the antimalarial activity, but both the trialkylated monopyrrole and enamine moiety are important. In summary, structure pruning of PGs has shown that in vitro potency can be retained and/or enhanced when moving from a tripyrrole (PGs) to bipyrrole (TAs) and even to a monopyrrole as shown in Figure 6.

In Vitro Antimalarial Activity of TA-like Analogues (190, 191, and 194-196), in Which the Ring-B Is Replaced by an Alkylamide/Amine Linkage. Our detailed SAR explorations around the ring- $\mathrm{A}$ and $-\mathrm{B}$ and nature of alkylamines of TAs led to a robust understanding of the structural features that 
Table 7. In Vivo Antimalarial Efficacy of PGs and TAs in a Murine P. yoelii

\begin{tabular}{|c|c|c|c|c|c|}
\hline compd & $\begin{array}{c}\text { compd } \\
\text { code names }\end{array}$ & structure & $\begin{array}{c}\text { dose } \\
(\mathrm{mg} / \mathrm{kg} \times 4 \\
\text { days) }\end{array}$ & $\begin{array}{l}\% \text { suppression of } \\
\text { parasitaemia on } \\
\text { day } 5^{\mathrm{b}}\end{array}$ & $\begin{array}{c}\mathrm{ED}_{50} \\
(\mathrm{mg} / \mathrm{kg} / \text { day })\end{array}$ \\
\hline control & - & - & PEG-400 & - & - \\
\hline \multirow[t]{4}{*}{$\mathbf{8 5}^{\mathrm{a}}$} & \multirow[t]{4}{*}{ KAR71 } & & 5 & 90 & \multirow[t]{4}{*}{2.8} \\
\hline & & & 25 & 100 & \\
\hline & & & 50 & 100 & \\
\hline & & & 100 & 100 & \\
\hline \multirow[t]{3}{*}{98} & \multirow[t]{3}{*}{ KAR276 } & & 5 & 66 & \multirow[t]{3}{*}{$<5$} \\
\hline & & & 25 & 100 & \\
\hline & & & 50 & 100 & \\
\hline \multirow[t]{4}{*}{100} & \multirow[t]{4}{*}{ KAR458 } & & 5 & 90 & \multirow[t]{4}{*}{$<5$} \\
\hline & & & 25 & 93 & \\
\hline & & & 50 & 96 & \\
\hline & & & 100 & 100 & \\
\hline \multirow[t]{4}{*}{105} & \multirow[t]{4}{*}{ KAR383 } & & 5 & 92 & \multirow[t]{4}{*}{$<5$} \\
\hline & & & 25 & 94 & \\
\hline & & & 50 & 96 & \\
\hline & & & 100 & 100 & \\
\hline \multirow[t]{4}{*}{108} & \multirow[t]{4}{*}{ KAR457 } & & 5 & 93 & \multirow[t]{4}{*}{$<5$} \\
\hline & & & 25 & 94 & \\
\hline & & & 50 & 99 & \\
\hline & & & 100 & 100 & \\
\hline \multirow[t]{4}{*}{109} & \multirow[t]{4}{*}{ KAR422 } & & 5 & 0 & \multirow[t]{4}{*}{84} \\
\hline & & & 25 & 27 & \\
\hline & & & 50 & 38 & \\
\hline & & & 100 & 97 & \\
\hline \multirow[t]{3}{*}{123} & \multirow[t]{3}{*}{ KAR790 } & & 5 & 30 & \multirow[t]{3}{*}{20} \\
\hline & & & 25 & 77 & \\
\hline & & & 50 & 100 & \\
\hline \multirow[t]{4}{*}{145} & \multirow[t]{4}{*}{ KAR425 } & & 5 & 100 & \multirow[t]{4}{*}{$<2.5$} \\
\hline & & & 25 & $100^{c}$ & \\
\hline & & & 50 & $100^{\mathrm{c}}$ & \\
\hline & & & 100 & 100 & \\
\hline 177 & KAR767 & & 5 & 7 & 5.5 \\
\hline & & & 25 & 100 & \\
\hline & & & 50 & 100 & \\
\hline & & & 100 & 100 & \\
\hline 185 & KAR765 & & 5 & 24 & 45 \\
\hline & & & 25 & 17 & \\
\hline & & & 50 & 67 & \\
\hline & & & 100 & 100 & \\
\hline CQ & - & - & 1 & 65 & 2.2 \\
\hline & & & 4 & 94 & \\
\hline & & & 16 & 100 & \\
\hline & & & 64 & 100 & \\
\hline
\end{tabular}

${ }^{a}$ Previous lead compound. ${ }^{37} b_{\%}$ suppression of parasitemia $=100 \times[($ parasitemia control group $)-($ parasitemia treated group $)] /$ parasitemia control group. ${ }^{c}$ Provided cures $(100 \%$ protection to malaria-infected mice).

are required for potent antimalarial activity. We also sought to explore whether any linkage (total replacement of ring-B) between two of the most active pharmacophores (i.e., 2-pyrrolyl and 1-adamantyl moieties) is tolerated. A set of novel TA-like analogues 190, 191, and 194-196, in which ring$\mathrm{B}$ is completely replaced by an alkylamide/amine linkage, were generated and screened for their antimalarial activity against $P f$ strains (Table 6). None of these analogues showed activity $\left(\mathrm{IC}_{50}>2500 \mathrm{nM}\right.$, Table 6). These data confirmed that the ring-B between ring-A and alkylamine plays an important role in the antimalarial activity of TAs and PGs as well.

In Vivo Efficacy Studies in Mice Models. Given the attractive antiplasmodial activity of several PGs and TAs against $\mathrm{CQ}^{\mathrm{S}}-\mathrm{D} 6, \mathrm{CQ}^{\mathrm{R}}-\mathrm{Dd} 2$, and $7 \mathrm{G} 8$ strains of $P$. falciparum along with 
favorable toxicological properties against hepatocellular HepG2 cancer cell line and lower MWT and lipophilic properties, an in vivo proof of concept study in a murine $P$. yoelii model was undertaken with the most potent and selective analogues 98, $100,105,108,109,123,145,177$, and 185 , using side by side comparison with our previous lead PG $\mathbf{8 5}^{37}$ and CQ as a reference drug (Table 7). In vivo efficacy was determined in a murine $P$. yoelii model, ${ }^{71,72}$ in which animals were randomly placed in groups of four and administered test drugs in the range of $5-100 \mathrm{mg} / \mathrm{kg}$ by oral gavage on 4 sequential days following the day of inoculation. The in vivo data are expressed as $\mathrm{ED}_{50}$ values and reflect the dose (estimated from doseresponse curves) for suppression of parasitemia by $50 \%$ relative to vehicle-only controls as assessed on day 5 of each study. In these experiments, the animals with parasitemia either on day 5 or later were euthanized and the parasitemia free animals were kept in observation until day 28. Drug treated animals that were parasitemia free on day 28 of the experiment are defined as "cures", and the amount of drug that was needed to achieve a cure is referred to as the "nonrecrudescence dose" (NRD).

Following four once-daily doses of PGs $\mathbf{8 5}$ and 98 at $5 \mathrm{mg} / \mathrm{kg}$, each reduced parasitemia by a $90 \%$ and $66 \%$ on day 5 , respectively, and parasitemia free animals were observed at 25 and $50-100 \mathrm{mg} / \mathrm{kg}$; however, none of these animals were cured, while the CQ was also not curative in this model even at doses as high as $64 \mathrm{mg} \mathrm{kg}^{-1} \mathrm{day}^{-1}$ (Table 7). The TA analogues 100, 105, and 108 each reduced parasitemia $>90 \%$ after 5, 25, and $50 \mathrm{mg} / \mathrm{kg} \times 4$ days dosing, and at the higher dose $(100 \mathrm{mg} / \mathrm{kg} \times$ 4 days) these reduced parasitemia $100 \%$ on day 5. Intriguingly, the TA 109 with good in vitro potency showed much less efficacy with an $\mathrm{ED}_{50}$ value of $84 \mathrm{mg} \mathrm{kg}^{-1} \mathrm{day}^{-1}$, which may relate to low aqueous solubility and/or poor oral bioavailability (Table 7). Interestingly the analogue 123, in which the methyl group of ring-B is replaced the OMe group of 109 , showed improved efficacy at all doses; specifically $100 \%$ reduction was observed at $50 \mathrm{mg} / \mathrm{kg} \times 4$ days on day 5 . Of these TAs, the analogue 145 with 3 -ethyl/4-methyl substitution pattern on the ring- $\mathrm{B}$ and the cycloheptylamine in the place of ring- $\mathrm{C}$ provided an excellent in vivo efficacy against $P$. yoelii in mice with an $\mathrm{ED}_{50}$ value of $<2.5 \mathrm{mg} \mathrm{kg}^{-1} \mathrm{day}^{-1}$, and it cleared all parasitemia on day 5 after dosing $5 \mathrm{mg} / \mathrm{kg}$ to $100 \mathrm{mg} / \mathrm{kg} \times 4$ days. Indeed, the compound 145 provided parasite-free cures on day $28(100 \%$ protection to malaria-infected mice) at 25 and $50 \mathrm{mg} \mathrm{kg}^{-1}$ day $^{-1}$, without evident weight loss and toxicity. In separate experiments, a single oral dose $(80 \mathrm{mg} / \mathrm{kg})$ of KAR425 (145) was also used. The preliminary experiments demonstrated that the KAR425 is also curative in this model and two of four mice were cured with no obvious signs of toxicity or behavior change; higher dose studies are underway in our laboratories. The analogues 177 and 185 showed $100 \%$ parasitemia reduction on day 5 after 25-100 mg/kg and $100 \mathrm{mg} / \mathrm{kg}$ dosing, respectively; however these were not curative in this model.

\section{CONCLUSIONS}

We report here the synthesis and antimalarial activity of the novel class of potent tambjamines (TAs) and B-ring functionalized prodiginines (PGs). The compounds were synthesized via simple and inexpensive chemical procedures using easily available building blocks to respond to the demand for low-cost novel antimalarial agents. When compared to tripyrrole PGs, ${ }^{37,38}$ these bipyrrole TAs exhibited marked improvements with regard to the color properties, in vitro potency, selectivity, and in vivo efficacy. Several key findings emerged from these studies: (i) the alkylated pyrrole (ring-C) can be replaced by an alkyl/ cycloalkylamine, providing for TAs with retained and/or enhanced antimalarial activity; (ii) the $\mathrm{OMe}$ group at the 4-position on the ring- $\mathrm{B}$, between ring-A and ring-C/alkylamine of PGs/TAs, can be replaced with short alkyl substitutions at either 4-position or 3- and 4-positions without impacting in vitro potency; (iii) the 2-pyrrolyl moiety (ring-A) must be linked at 2-position on the ring-B for potency, and it can be substituted with alkyl groups (see Figure 7). In addition, these analogues are equally effective against $P$. falciparum pansensitive D6 and MDR Dd2 and 7G8 strains. Some of these analogues have shown very promising in vivo efficacy in mice; specifically, the KAR425 (145) TA offered greater efficacy than previously observed for any tripyrrole $\mathrm{PG}$, providing $100 \%$ protection to malaria-infected mice until day 28 at doses of 25 and $50 \mathrm{mg} / \mathrm{kg} \times$ 4 days, and was also curative in this model in a single oral dose $(80 \mathrm{mg} / \mathrm{kg})$. In our overall study, the KAR425 stands out as an excellent lead compound, with low molecular weight $(<300)$, good lipophilic profile $(\operatorname{cog} P<2.7)$, oral efficacy, and no obvious signs of toxicity or behavior change. Detailed lead optimization, pharmacology, safety, and modes of action studies of the KAR425 will be studied in our laboratories in due course to produce the antimalarial candidates for full preclinical studies.

\section{EXPERIMENTAL SECTION}

General. NMR spectra were recorded on Bruker AMX-400 and AMX-600, spectrometers at $400,600 \mathrm{MHz}\left({ }^{1} \mathrm{H}\right)$ and $100,150 \mathrm{MHz}$ $\left({ }^{13} \mathrm{C}\right)$. Experiments were recorded in $\mathrm{CDCl}_{3}, \mathrm{CD}_{3} \mathrm{OD}$, acetone- $d_{6}$, and DMSO- $d_{6}$ at $25{ }^{\circ} \mathrm{C}$. Chemical shifts are given in parts per million (ppm) downfield from internal standard $\mathrm{Me}_{4} \mathrm{Si}$ (TMS). HRMS (ESI) were recorded on a high-resolution (30000) thermo LTQ-Orbitrap Discovery hybrid mass spectrometer (San Jose, CA). Unless otherwise stated, all reagents and solvents were purchased from commercial suppliers and used without further purification. Reactions that required the use of anhydrous, inert atmosphere techniques were carried out under an atmosphere of argon/nitrogen. Chromatography was executed on CombiFlash Rf 200 instrument, using silica gel (230-400 mesh) and/or neutral alumina as the stationary phase and mixtures of ethyl acetate and hexane as eluents. Analytical HPLC analyses were performed on a Supelco Discovery HS C18 column $(4.6 \mathrm{~mm} \times 250 \mathrm{~mm})$ with a linear elution gradient ranging from $\mathrm{CH}_{3} \mathrm{OH} / \mathrm{CH}_{3} \mathrm{CN} / \mathrm{H}_{2} \mathrm{O}$ $(40 \% / 10 \% / 50 \%)$ to $\mathrm{CH}_{3} \mathrm{OH}(100 \%)$ in $0.15 \%$ trifluoroacetic acid at a flow rate of $1 \mathrm{~mL} / \mathrm{min}$. A purity of $\geq 95 \%$ has been established for all tested compounds.

Synthesis of 4-Hydroxy-2-oxo-2,5-dihydropyrrole-1-carboxylic Acid tert-Butyl Ester (45). To a stirred solution of $\mathrm{N}$-(tert-butoxycarbonyl)glycine $(44 ; 5.0 \mathrm{~g}, 28.57 \mathrm{mmol})$ in $90 \mathrm{~mL}$ of anhydrous $\mathrm{CH}_{2} \mathrm{Cl}_{2}$ (DCM) were added Meldrum's acid (4.93 g, $34.28 \mathrm{mmol}$ ) and 4-dimethylaminopyridine (DMAP; $8.71 \mathrm{~g}, 71.42 \mathrm{mmol}$ ) under an argon atmosphere at $0{ }^{\circ} \mathrm{C}$. A solution of isopropyl chloroformate $(42.85 \mathrm{~mL}, 42.85 \mathrm{mmol}, 1 \mathrm{~N}$ in toluene) was added dropwise, and the reaction mixture was stirred for $4 \mathrm{~h}$ at $0{ }^{\circ} \mathrm{C}$. The reaction mixture was diluted with DCM $(100 \mathrm{~mL})$, washed with $15 \% \mathrm{KHSO}_{4}$ $(2 \times 70 \mathrm{~mL})$, and organic layer was dried over $\mathrm{Na}_{2} \mathrm{SO}_{4}$, and the solvent was evaporated under reduced pressure to give the acylated Meldrum's acid. This material was then refluxed in ethyl acetate $(600 \mathrm{~mL})$ for $1 \mathrm{~h}$, and the solvent was evaporated under reduced pressure, and the product was recrystallized from ethyl acetate to give the desired product $45(3.46 \mathrm{~g}, 61 \%)$ as a white solid. ${ }^{1} \mathrm{H}$ NMR $\left(\right.$ DMSO$\left.d_{6}, 400 \mathrm{MHz}\right) \delta 12.13$ (br s, $\left.1 \mathrm{H}\right), 4.88(\mathrm{~s}, 1 \mathrm{H}), 4.14(\mathrm{~s}, 2 \mathrm{H})$, $1.44(\mathrm{~s}, 9 \mathrm{H})$; HRMS (ESI) calcd for $\mathrm{C}_{9} \mathrm{H}_{13} \mathrm{NaNO}_{4}(\mathrm{M}+\mathrm{Na})^{+}$ 222.0737 , found 222.0740 .

Synthessis of 2-Oxo-4-(toluene-4-sulfonyloxy)-2,5-dihydropyrrole-1-carboxylic Acid tert-Butyl Ester (46). To a stirred solution of $45(3.4 \mathrm{~g}, 17.08 \mathrm{mmol})$ in anhydrous $\mathrm{CH}_{2} \mathrm{Cl}_{2}(150 \mathrm{~mL})$ were added $p$-toluenesulfonyl chloride $(3.24 \mathrm{~g}, 17.08 \mathrm{mmol})$ and DIPEA ( $4.4 \mathrm{~g}, 34.17 \mathrm{mmol}$ ). The resulting reaction mixture was stirred 
for $6 \mathrm{~h}$ at $25^{\circ} \mathrm{C}$. Then the reaction mixture was washed with $5 \% \mathrm{HCl}$ $(2 \times 25 \mathrm{~mL})$, brine and dried over anhydrous $\mathrm{Na}_{2} \mathrm{SO}_{4}$. The organic solvent was removed under reduced pressure and the product was chromatographed on silica gel, with ethyl acetate/hexanes as eluent, to afford $46(5.37 \mathrm{~g}, 89 \%)$ as a white solid. ${ }^{1} \mathrm{H} \mathrm{NMR}\left(\mathrm{CDCl}_{3}, 400 \mathrm{MHz}\right)$ $\delta 7.86(\mathrm{~d}, J=8.4 \mathrm{~Hz}, 2 \mathrm{H}), 7.42(\mathrm{~d}, J=8.4 \mathrm{~Hz}, 2 \mathrm{H}), 5.75(\mathrm{~s}, 1 \mathrm{H}), 4.22$ (d, $J=1.2 \mathrm{~Hz}, 2 \mathrm{H}), 2.50(\mathrm{~s}, 3 \mathrm{H}), 1.52(\mathrm{~s}, 9 \mathrm{H})$; HRMS (ESI) calcd for $\mathrm{C}_{16} \mathrm{H}_{19} \mathrm{NaNO}_{6} \mathrm{~S}(\mathrm{M}+\mathrm{Na})^{+} 376.0825$, found 376.0830 .

Synthesis of 4-(4-Chlorophenyl)-2-oxo-2,5-dihydropyrrole1-carboxylic Acid tert-Butyl Ester (47). To a degassed stirred solution of $46(4.0 \mathrm{~g}, 11.33 \mathrm{mmol})$ and 4-chlorophenylboronic acid (2.65 g, $17.0 \mathrm{mmol})$ in $100 \mathrm{~mL}$ of THF at room temperature were added $\mathrm{Pd}(\mathrm{dppf}) \mathrm{Cl}_{2}(410 \mathrm{mg}, 0.56 \mathrm{mmol})$ and a solution of cesium carbonate $(11.05 \mathrm{~g}, 34.0 \mathrm{mmol})$ in water $(15 \mathrm{~mL})$. The reaction mixture was stirred at $25^{\circ} \mathrm{C}$ for $1 \mathrm{~h}$ and then heated to reflux for $16 \mathrm{~h}$. The reaction mixture was filtered through Celite and washed with ethyl acetate $(400 \mathrm{~mL})$. The organic layer was washed with saturated sodium bicarbonate $(2 \times 75 \mathrm{~mL})$ and brine and dried over anhydrous $\mathrm{Na}_{2} \mathrm{SO}_{4}$. Then the organic solution was concentrated under reduced pressure and the product was chromatographed on silica gel, with ethyl acetate/hexanes as eluent, to afford the pure product $47(1.82 \mathrm{~g}, 55 \%)$ as a white solid. ${ }^{1} \mathrm{H}$ NMR $\left(\mathrm{CDCl}_{3}, 400 \mathrm{MHz}\right) \delta 7.50(\mathrm{~d}, J=8.7 \mathrm{~Hz}$, $2 \mathrm{H}), 7.42(\mathrm{~d}, J=8.7 \mathrm{~Hz}, 2 \mathrm{H}), 6.42(\mathrm{t}, J=1.5 \mathrm{~Hz}, 1 \mathrm{H}), 4.68(\mathrm{~d}, J=$ $1.5 \mathrm{~Hz}, 2 \mathrm{H}), 1.61(\mathrm{~s}, 9 \mathrm{H})$; HRMS (ESI) calcd for $\mathrm{C}_{15} \mathrm{H}_{16} \mathrm{NaClNO}_{3}$ $(\mathrm{M}+\mathrm{Na})^{+} 316.0711$, found 316.0713 .

Synthesis of 4-(4-Chlorophenyl)-1,5-dihydropyrrol-2-one (48). To a stirred solution of $47(1.8 \mathrm{~g}, 6.14 \mathrm{mmol})$ in anhydrous $\mathrm{CH}_{2} \mathrm{Cl}_{2}(25 \mathrm{~mL})$ was added dropwise TFA $(2.8 \mathrm{~g}, 24.57 \mathrm{mmol})$. The reaction mixture was stirred for an additional hour at $25{ }^{\circ} \mathrm{C}$. The solvent was evaporated under reduced pressure, and the crude material was then dissolved in ethyl acetate $(200 \mathrm{~mL})$. The organic layer was washed with $5 \% \mathrm{NaHCO}_{3}$ and brine and dried over anhydrous $\mathrm{Na}_{2} \mathrm{SO}_{4}$. The organic solvent was evaporated under reduced pressure and the solid material was washed with $\mathrm{CH}_{2} \mathrm{Cl}_{2}$ to afford the pure product $48(1.14 \mathrm{~g}, 94 \%)$ as a white solid. ${ }^{1} \mathrm{H}$ NMR (DMSO- $d_{6}$ $400 \mathrm{MHz}) \delta 8.15(\mathrm{br} \mathrm{s}, 1 \mathrm{H}), 7.61(\mathrm{~d}, J=8.6 \mathrm{~Hz}, 2 \mathrm{H}), 7.44(\mathrm{~d}, J=8.6$ $\mathrm{Hz}, 2 \mathrm{H}), 6.50(\mathrm{t}, J=1.5 \mathrm{~Hz}, 1 \mathrm{H}), 4.30(\mathrm{~s}, 2 \mathrm{H})$; HRMS (ESI) calcd for $\mathrm{C}_{10} \mathrm{H}_{9}$ ClNO $(\mathrm{M}+\mathrm{H})^{+}$194.0367, found 194.0372.

Synthesis of 5-Bromo-3-(4-chlorophenyl)pyrrole-2-carboxaldehyde (49). To a stirred solution of diethylformamide (DEF; $1.57 \mathrm{~g}, 15.54 \mathrm{mmol})$ in anhydrous chloroform $(10 \mathrm{~mL})$ at $0{ }^{\circ} \mathrm{C}$ was added dropwise a solution of phosphorus oxybromide $\left(\mathrm{POBr}_{3} ; 3.62 \mathrm{~g}\right.$, $12.95 \mathrm{mmol})$ in chloroform $(10 \mathrm{~mL})$. The resulting thick suspension was stirred at $0{ }^{\circ} \mathrm{C}$ for $30 \mathrm{~min}$ to obtain the Vilsmeier complex as a solid. After the sample was dried in vacuo for $20 \mathrm{~min}$, chloroform $(50 \mathrm{~mL})$ was added to the solid and the reaction mixture was cooled to $0{ }^{\circ} \mathrm{C}$. The compound $48(1.0 \mathrm{~g}, 5.18 \mathrm{mmol})$ was added portionwise, and the reaction mixture was warmed to room temperature and then heated at $70{ }^{\circ} \mathrm{C}$ for $16 \mathrm{~h}$. The reaction mixture was poured onto icewater $(75 \mathrm{~mL})$, and the $\mathrm{pH}$ of the aqueous solution was adjusted to $\mathrm{pH} 9-10$ by treatment with $5 \mathrm{~N} \mathrm{NaOH}$. Dichloromethane $(100 \mathrm{~mL})$ was added to the resulting precipitate, and the mixture was filtered through Celite. The two layers were separated, and the aqueous layer was extracted with $\mathrm{CH}_{2} \mathrm{Cl}_{2}(3 \times 100 \mathrm{~mL})$. The organic layers were combined, washed with brine, and dried over anhydrous $\mathrm{Na}_{2} \mathrm{SO}_{4}$. The solvent was removed under reduced pressure and the product was passed through a silica gel, with ethyl acetate/hexanes as eluent, to afford the pure $49(806 \mathrm{mg}, 55 \%)$ as a white solid. ${ }^{1} \mathrm{H} \mathrm{NMR}\left(\mathrm{CDCl}_{3}\right.$, $400 \mathrm{MHz}) \delta 10.05(\mathrm{br} \mathrm{s}, 1 \mathrm{H}), 9.49(\mathrm{~s}, 1 \mathrm{H}), 7.49-7.40(\mathrm{~m}, 4 \mathrm{H}), 6.42$ $(\mathrm{d}, J=2.6 \mathrm{~Hz}, 1 \mathrm{H}) ;{ }^{13} \mathrm{C} \mathrm{NMR}\left(\mathrm{CDCl}_{3}, 100 \mathrm{MHz}\right) \delta 178.2,137.1$, 134.5, 131.5, 130.9, 130.3, 129.9, 129.1, 128.9, 113.6, 113.1; HRMS (ESI) calcd for $\mathrm{C}_{11} \mathrm{H}_{8} \mathrm{BrClNO}(\mathrm{M}+\mathrm{H})^{+} 283.9472$, found 283.9484 .

Representative Procedure for the Synthesis of 4-(4-Chlorophenyl)-[2,2']bipyrrolyl-5-carboxaldehyde (9). To a degassed stirred solution of $49(1.0 \mathrm{~g}, 3.53 \mathrm{mmol})$ and $\mathrm{N}$-Boc-2-pyrroleboronic acid $(1.11 \mathrm{~g}, 5.30 \mathrm{mmol})$ in $10 \%$ water/dioxane $(50 \mathrm{~mL})$ were added $\mathrm{Pd}\left(\mathrm{PPh}_{3}\right)_{4}(204 \mathrm{mg}, 0.17 \mathrm{mmol})$ and $\mathrm{Na}_{2} \mathrm{CO}_{3}(749 \mathrm{mg}, 7.06 \mathrm{mmol})$. The reaction mixture was stirred for $3 \mathrm{~h}$ at $100{ }^{\circ} \mathrm{C}$ and poured onto water $(100 \mathrm{~mL})$. The $\mathrm{pH}$ of the solution was lowered to $\mathrm{pH} 7$ with $2 \mathrm{~N} \mathrm{HCl}$ and extracted with ethyl acetate $(3 \times 75 \mathrm{~mL})$. The combined organic layers were washed with water and brine and dried over anhydrous $\mathrm{Na}_{2} \mathrm{SO}_{4}$. The solvent was evaporated under reduced pressure and the residue was dissolved in methanol $(25 \mathrm{~mL})$ and evaporated the solvent to remove the volatile $\mathrm{B}(\mathrm{OMe})_{3}$. This was then dissolved in THF $(10 \mathrm{~mL})$, and $\mathrm{LiOH}(850 \mathrm{mg}, 35.33 \mathrm{mmol})$ in methanol $(10 \mathrm{~mL})$ was added dropwise under an argon atmosphere at room temperature. The resulting reaction mixture was stirred at room temperature for $30 \mathrm{~min}$. On completion of the reaction, the solvent was removed under reduced pressure. The resulting solid was picked up with ethyl acetate $(200 \mathrm{~mL})$, washed with water and brine, and dried over anhydrous $\mathrm{Na}_{2} \mathrm{SO}_{4}$. The organic solvent was removed under reduced pressure and the product was chromatographed on silica gel, with ethyl acetate/hexanes as eluent, to afford the pure 9 (562 mg, 59\%). ${ }^{1} \mathrm{H}$ NMR (DMSO- $\left.d_{6}, 400 \mathrm{MHz}\right) \delta 12.09$ (br s, $1 \mathrm{H}$ ), $11.31($ br s, $1 \mathrm{H}), 9.46(\mathrm{~s}, 1 \mathrm{H}), 7.58(\mathrm{~d}, J=8.7 \mathrm{~Hz}, 2 \mathrm{H}), 7.52(\mathrm{~d}, J=8.7$ $\mathrm{Hz}, 2 \mathrm{H}), 6.93(\mathrm{~m}, 1 \mathrm{H}), 6.81(\mathrm{~m}, 1 \mathrm{H}), 6.72(\mathrm{~d}, J=2.5 \mathrm{~Hz}, 1 \mathrm{H}), 6.14$ $(\mathrm{m}, 1 \mathrm{H}) ;{ }^{13} \mathrm{C}$ NMR (DMSO- $\left.d_{6}, 100 \mathrm{MHz}\right) \delta 177.1,135.6,133.6$, 132.6, 132.3, 130.5 (2C), 128.7 (2C), 127.5, 123.0, 120.2, 109.3, 108.1, 106.4; HRMS (ESI) calcd for $\mathrm{C}_{15} \mathrm{H}_{12} \mathrm{ClN}_{2} \mathrm{O}(\mathrm{M}+\mathrm{H})^{+}$271.0633, found 271.0639 .

Synthesis of 5-Chloropyrrole-2-carboxaldehyde (51). To a stirred solution of pyrrole (50; $5.0 \mathrm{~g}, 74.62 \mathrm{mmol})$ in $200 \mathrm{~mL}$ of dry THF was added $N$-chlorosuccinimide (NCS; $9.92 \mathrm{~g}, 74.62 \mathrm{mmol}$ ) under an argon atmosphere at $-78{ }^{\circ} \mathrm{C}$. The reaction mixture was stirred for an additional $4 \mathrm{~h}$ at the same temperature and placed at $-20^{\circ} \mathrm{C}$ for overnight. To the reaction mixture was added dropwise Vilsmeier reagent $\left(149.25 \mathrm{mmol}\right.$, in situ generation from $\mathrm{POCl}_{3} / \mathrm{DMF}, 0{ }^{\circ} \mathrm{C}$, $1 \mathrm{~h}$ ) in $100 \mathrm{~mL}$ of DCM at $-20^{\circ} \mathrm{C}$. The reaction mixture was stirred for $10 \mathrm{~h}$ while it was allowed to warm to room temperature. The solvent was removed under reduced pressure, and $100 \mathrm{~mL}$ of water was added. To the stirred mixture, sodium hydroxide $(2 \mathrm{~N}, 100 \mathrm{~mL})$ was added slowly, and the reaction mixture was allowed to stir for $1 \mathrm{~h}$ at room temperature. Ethyl acetate $(300 \mathrm{~mL})$ was added to the resulting precipitate, the two layers were separated, and the aqueous layer was further extracted with ethyl acetate $(2 \times 100 \mathrm{~mL})$. The organic layers were combined, washed with brine, and dried over anhydrous $\mathrm{Na}_{2} \mathrm{SO}_{4}$. The solvent was removed by rotary evaporation and the product was chromatographed on silica gel, with ethyl acetate/ hexanes as eluent, to afford the desired product $51(3.46 \mathrm{~g}, 36 \%)$ as a white solid. ${ }^{1} \mathrm{H}$ NMR $\left(\mathrm{CDCl}_{3}, 400 \mathrm{MHz}\right) \delta 12.28(\mathrm{br} \mathrm{s}, 1 \mathrm{H}), 9.31$ (s, $1 \mathrm{H}), 6.85(\mathrm{dd}, J=2.3,4.0 \mathrm{~Hz}, 1 \mathrm{H}), 6.14(\mathrm{dd}, J=2.3,4.0 \mathrm{~Hz}, 1 \mathrm{H}) ;{ }^{13} \mathrm{C}$ NMR $\left(\mathrm{CDCl}_{3}, 100 \mathrm{MHz}\right) \delta 178.2,131.9,126.0,122.4,110.0$; HRMS (ESI) calcd for $\mathrm{C}_{5} \mathrm{H}_{5} \mathrm{ClNO}(\mathrm{M}+\mathrm{H})^{+} 130.0054$, found 130.0055 .

Synthesis of $\left[2,2^{\prime}\right.$-Bipyrrole]-5-carboxaldehyde (19). Compound 19 (558 $\mathrm{mg}, 45 \%$ ) was synthesized by the same procedure as described for 9. ${ }^{1} \mathrm{H}$ NMR $\left(\mathrm{CDCl}_{3}, 400 \mathrm{MHz}\right) \delta 11.98(\mathrm{br} \mathrm{s}, 1 \mathrm{H})$ $11.24($ br s, $1 \mathrm{H}), 9.35(\mathrm{~s}, 1 \mathrm{H}), 7.00(\mathrm{dd}, J=2.3,3.9 \mathrm{~Hz}, 1 \mathrm{H}), 6.89(\mathrm{~m}$, $1 \mathrm{H}), 6.73(\mathrm{~m}, 1 \mathrm{H}), 6.54(\mathrm{dd}, J=2.3,3.9 \mathrm{~Hz}, 1 \mathrm{H}), 6.12(\mathrm{~m}, 1 \mathrm{H})$; HRMS (ESI) calcd for $\mathrm{C}_{9} \mathrm{H}_{9} \mathrm{~N}_{2} \mathrm{O}(\mathrm{M}+\mathrm{H})^{+} 161.0709$, found 161.0713.

Synthesis of Ethyl 4,5,6,7-Tetrahydroisoindole-1-carboxylate (53). To a stirred solution of $52(5.0 \mathrm{~g}, 39.37 \mathrm{mmol})$ and ethyl isocyanoacetate $(5.33 \mathrm{~g}, 47.24 \mathrm{mmol})$ in 1:1 mixture of THF and ethanol $(100 \mathrm{~mL})$ was added portionwise anhydrous potassium carbonate $(10.86 \mathrm{~g}, 78.74 \mathrm{mmol})$. The reaction mixture was then stirred at room temperature for 3 days. The mixture was poured into water $(100 \mathrm{~mL})$, acidified to $\mathrm{pH} 5$ with $2 \mathrm{~N} \mathrm{HCl}$, and extracted with diethyl ether $(3 \times 100 \mathrm{~mL})$. The combined organic layers were washed with brine and dried over anhydrous $\mathrm{Na}_{2} \mathrm{SO}_{4}$. The solvent was evaporated under reduced pressure and the product was chromatographed on silica gel, with ethyl acetate/hexanes as eluent, to afford the pure product 53 (4.93 g, 65\%) as a white solid. ${ }^{1} \mathrm{H}$ NMR $\left(\mathrm{CDCl}_{3}, 400 \mathrm{MHz}\right)$ $\delta 9.28(\mathrm{br} \mathrm{s}, 1 \mathrm{H}), 6.67(\mathrm{~d}, J=2.9 \mathrm{~Hz}, 1 \mathrm{H}), 4.33(\mathrm{q}, J=7.1 \mathrm{~Hz}, 2 \mathrm{H})$, $2.85(\mathrm{t}, J=5.8 \mathrm{~Hz}, 2 \mathrm{H}), 2.57(\mathrm{t}, J=6.0 \mathrm{~Hz}, 2 \mathrm{H}), 1.77(\mathrm{~m}, 4 \mathrm{H}), 1.38(\mathrm{t}$, $J=7.1 \mathrm{~Hz}, 3 \mathrm{H})$; HRMS $($ ESI $)$ calcd for $\mathrm{C}_{11} \mathrm{H}_{16} \mathrm{NO}_{2}(\mathrm{M}+\mathrm{H})^{+}$ 194.1176, found 194.1184 .

Synthesis of 4,5,6,7-Tetrahydroisoindole (54). Sodium hydroxide $(1.47 \mathrm{~g}, 36.71 \mathrm{mmol})$ was added to a solution of $53(3.8 \mathrm{~g}, 18.35 \mathrm{mmol})$ in anhydrous ethylene glycol $(20 \mathrm{~mL})$ under an argon atmosphere at room temperature, and the reaction mixture was heated to reflux and stirred at refluxing temperature for an hour. After cooling to room temperature, 
the reaction mixture was taken up in $n$-hexane, washed with water and dried over anhydrous $\mathrm{Na}_{2} \mathrm{SO}_{4}$. Evaporation of the solvent under reduced pressure afforded the $54(2.0 \mathrm{~g}, 90 \%)$ as a white solid that was directly used in the next step without further purification. ${ }^{1} \mathrm{H} \mathrm{NMR}\left(\mathrm{CDCl}_{3}\right.$, $400 \mathrm{MHz}) \delta 7.92$ (br s, $1 \mathrm{H}), 6.53(\mathrm{~d}, J=2.6 \mathrm{~Hz}, 2 \mathrm{H}), 2.67(\mathrm{~m}, 4 \mathrm{H})$, $1.80(\mathrm{~m}, 4 \mathrm{H})$; HRMS (ESI) calcd for $\mathrm{C}_{8} \mathrm{H}_{12} \mathrm{~N}(\mathrm{M}+\mathrm{H})^{+}$122.0964, found 122.0969 .

Representative Procedure for the Synthesis of 4,5,6,7Tetrahydroisoindole-1-carboxaldehyde (55) by Standard Vilsmeier Conditions. Phosphorus oxychloride $\left(\mathrm{POCl}_{3} ; 5.05 \mathrm{~g}, 33.05\right.$ $\mathrm{mmol}$ ) was added dropwise to dimethylformamide (DMF; $2.41 \mathrm{~g}$, $33.05 \mathrm{mmol}$ ) at $0{ }^{\circ} \mathrm{C}$. The resulting solution was stirred at $0{ }^{\circ} \mathrm{C}$ until the formation of the Vilsmeier complex as a solid. After the solid was dried in vacuo for $20 \mathrm{~min}$, dichloromethane $(50 \mathrm{~mL})$ was added to the solid and the reaction mixture was cooled to $0{ }^{\circ} \mathrm{C}$. A solution of $\mathbf{5 4}$ $(2.0 \mathrm{~g}, 16.52 \mathrm{mmol})$ in DCM $(50 \mathrm{~mL})$ was added dropwise, and the reaction mixture was warmed to room temperature and then stirred for $10 \mathrm{~h}$. After removal of all solvent under vacuo, the residue was mixed with water $(100 \mathrm{~mL})$. To the stirred mixture, sodium hydroxide $(5.28 \mathrm{~g}, 132.23 \mathrm{mmol})$ was added slowly, and the reaction mixture was allowed to stir for $1 \mathrm{~h}$ at room temperature. Ethyl acetate $(200 \mathrm{~mL})$ was added to the resulting precipitate, the two layers were separated, and the aqueous layer was further extracted with ethyl acetate $(2 \times 50 \mathrm{~mL})$. The organic layers were combined, washed with brine, and dried over anhydrous $\mathrm{Na}_{2} \mathrm{SO}_{4}$. The solvent was removed by rotary evaporation and the product was chromatographed on silica gel, with ethyl acetate/hexanes as eluent, to afford the desired product $\mathbf{5 5}$ (1.84 g, 75\%) as a white solid. ${ }^{1} \mathrm{H} \mathrm{NMR}\left(\mathrm{CDCl}_{3}, 400 \mathrm{MHz}\right) \delta 10.23$ (br s, $1 \mathrm{H}), 9.51(\mathrm{~s}, 1 \mathrm{H}), 6.87(\mathrm{~d}, J=2.8 \mathrm{~Hz}, 1 \mathrm{H}), 2.86(\mathrm{t}, J=5.9 \mathrm{~Hz}$, $2 \mathrm{H}), 2.55(\mathrm{t}, J=6.0 \mathrm{~Hz}, 2 \mathrm{H}), 1.80(\mathrm{~m}, 4 \mathrm{H})$; HRMS (ESI) calcd for $\mathrm{C}_{9} \mathrm{H}_{12} \mathrm{NO}(\mathrm{M}+\mathrm{H})^{+} 150.0913$, found 150.0920 .

Representative Procedure for the Synthesis of 3-Bromo4,5,6,7-tetrahydroisoindole-1-carboxaldehyde (56). To a stirred solution of $55(2.0 \mathrm{~g}, 13.42 \mathrm{mmol})$ in THF $(100 \mathrm{~mL})$ was added portionwise DBDMH $(1.90 \mathrm{~g}, 6.71 \mathrm{mmol})$ in a period of $10 \mathrm{~min}$ at $-78{ }^{\circ} \mathrm{C}$. Then the reaction mixture was stirred for $5 \mathrm{~h}$ while it was allowed to warm to room temperature. The reaction was quenched with $5 \%$ aqueous $\mathrm{KHSO}_{4}$ solution and extracted with ethyl acetate $(3 \times 75 \mathrm{~mL})$. The combined organic layers were washed with brine and dried over anhydrous $\mathrm{Na}_{2} \mathrm{SO}_{4}$. The solvent was evaporated under reduced pressure and the product was chromatographed on silica gel, with ethyl acetate/hexanes as eluent, to afford the pure product 56 (2.48 g, 82\%). ${ }^{1} \mathrm{H} \mathrm{NMR}\left(\mathrm{CDCl}_{3}, 400 \mathrm{MHz}\right) \delta 10.60$ (br s, $\left.1 \mathrm{H}\right), 9.41$ (s, $1 \mathrm{H}), 2.83(\mathrm{~m}, 2 \mathrm{H}), 2.42(\mathrm{~m}, 2 \mathrm{H}), 1.77(\mathrm{~m}, 4 \mathrm{H}) ;{ }^{13} \mathrm{C}$ NMR $\left(\mathrm{CDCl}_{3}, 100 \mathrm{MHz}\right) \delta 175.7,134.7,128.9,122.7,110.5,22.8,22.6$, 21.3, 21.0; HRMS (ESI) calcd for $\mathrm{C}_{9} \mathrm{H}_{11} \mathrm{BrNO}(\mathrm{M}+\mathrm{H})^{+} 228.0019$, found 228.0031 .

Synthesis of 3-(Pyrrol-2-yl)-4,5,6,7-tetrahydroisoindole-1carboxaldehyde (20). Compound 20 (682 mg, 72\%) was synthesized by the same procedure as described for 9. ${ }^{1} \mathrm{H}$ NMR (DMSO-d $\left.+\mathrm{CDCl}_{3}, 400 \mathrm{MHz}\right) \delta 10.64$ (br s, $\left.1 \mathrm{H}\right), 10.35$ (br s, $\left.1 \mathrm{H}\right), 8.77$ (s, $\left.1 \mathrm{H}\right)$, $6.21(\mathrm{~s}, 1 \mathrm{H}), 5.81(\mathrm{~s}, 1 \mathrm{H}), 5.56(\mathrm{~s}, 1 \mathrm{H}), 2.19(\mathrm{~s}, 2 \mathrm{H}), 1.98(\mathrm{~s}, 2 \mathrm{H}), 1.16$ $(\mathrm{m}, 4 \mathrm{H}) ;{ }^{13} \mathrm{C}$ NMR (DMSO- $\left.d_{6}+\mathrm{CDCl}_{3}, 100 \mathrm{MHz}\right) \delta 173.0,133.1$, $128.8,125.6,122.5,117.9,116.7,108.2,107.5,21.9,21.5,21.1,19.6$; HRMS (ESI) calcd for $\mathrm{C}_{13} \mathrm{H}_{15} \mathrm{~N}_{2} \mathrm{O}(\mathrm{M}+\mathrm{H})^{+} 215.1179$, found 215.1188.

Synthesis of Compounds 59-62. Compounds 59 (1.36 g, 75\%), $60(1.27 \mathrm{~g}, 78 \%), 61(1.35 \mathrm{~g}, 79 \%)$, and $62(1.35 \mathrm{~g}, 83 \%)$ were synthesized by the same procedure as described for $\mathbf{5 6}$.

4-Bromopyrrole-2-carboxaldehyde (59). ${ }^{1} \mathrm{H} \mathrm{NMR}\left(\mathrm{CDCl}_{3}, 400\right.$ $\mathrm{MHz}) \delta 10.16$ (br s, $1 \mathrm{H}), 9.49(\mathrm{~d}, J=1.0 \mathrm{~Hz}, 1 \mathrm{H}), 7.15(\mathrm{~m}, 1 \mathrm{H}), 7.00$ $(\mathrm{m}, 1 \mathrm{H})$; HRMS (ESI) calcd for $\mathrm{C}_{5} \mathrm{H}_{5} \mathrm{BrNO}(\mathrm{M}+\mathrm{H})^{+}$173.9549, found 173.9555 .

4-Bromo-3,5-dimethylpyrrole-2-carboxaldehyde (60). ${ }^{1} \mathrm{H}$ NMR $\left(\mathrm{CDCl}_{3}, 400 \mathrm{MHz}\right) \delta 10.82$ (br s, $\left.1 \mathrm{H}\right), 9.45(\mathrm{~s}, 1 \mathrm{H}), 2.36(\mathrm{~s}, 3 \mathrm{H})$, $2.28(\mathrm{~s}, 3 \mathrm{H}) ;{ }^{13} \mathrm{C} \mathrm{NMR}\left(\mathrm{CDCl}_{3}, 100 \mathrm{MHz}\right) \delta 176.2,137.0,133.0$, 127.7, 101.5, 12.2, 10.0; HRMS (ESI) calcd for $\mathrm{C}_{7} \mathrm{H}_{9} \mathrm{BrNO}(\mathrm{M}+\mathrm{H})^{+}$ 201.9862, found 201.9871 .

4-Bromo-3-methylpyrrole-2-carboxaldehyde (61). ${ }^{1} \mathrm{H} \quad \mathrm{NMR}$ (acetone- $\left.d_{6}, 400 \mathrm{MHz}\right) \delta 11.17$ (br s, $\left.1 \mathrm{H}\right), 9.69$ (d, $\left.J=0.7 \mathrm{~Hz}, 1 \mathrm{H}\right)$, $7.25(\mathrm{~d}, J=3.2 \mathrm{~Hz}, 1 \mathrm{H}), 2.32(\mathrm{~s}, 3 \mathrm{H})$; HRMS (ESI) calcd for $\mathrm{C}_{6} \mathrm{H}_{7} \mathrm{BrNO}(\mathrm{M}+\mathrm{H})^{+}$187.9705, found 187.9711 .

4-Bromo-3-ethylpyrrole-2-carboxaldehyde (62). ${ }^{1} \mathrm{H} \mathrm{NMR}\left(\mathrm{CDCl}_{3}\right.$, $400 \mathrm{MHz}) \delta 10.08(\mathrm{br} \mathrm{s}, 1 \mathrm{H}), 9.34(\mathrm{~s}, 1 \mathrm{H}), 7.20(\mathrm{~d}, J=2.6 \mathrm{~Hz}, 1 \mathrm{H})$, $2.47(\mathrm{q}, J=7.6 \mathrm{~Hz}, 2 \mathrm{H}), 1.25(\mathrm{t}, J=7.6 \mathrm{~Hz}, 3 \mathrm{H})$; HRMS (ESI) calcd for $\mathrm{C}_{7} \mathrm{H}_{9} \mathrm{BrNO}(\mathrm{M}+\mathrm{H})^{+}$201.9862, found 201.9869.

Synthesis of 22-25. Compounds 22 (647 mg, 70\%), 23 (673 mg, $72 \%), 24$ (623 mg, 67\%), and 25 (608 $\mathrm{mg}, 65 \%)$ were synthesized by the same procedure as described for 9 , with modification of the reaction conditions for deprotection of $\mathrm{N}$-Boc group. The crude material was dissolved in THF $(10 \mathrm{~mL})$, and $\mathrm{LiOH}$ (10 equiv) in methanol $(10 \mathrm{~mL})$ was added dropwise under an argon atmosphere. The resulting mixture was stirred at $60^{\circ} \mathrm{C}$ for $2 \mathrm{~h}$.

[2,3'-Bipyrrole]-5'-carboxaldehyde (22). ${ }^{1} \mathrm{H}$ NMR $\left(\mathrm{CD}_{3} \mathrm{OD}, 400\right.$ MHz) $\delta 9.43(\mathrm{~d}, J=1.0 \mathrm{~Hz}, 1 \mathrm{H}), 7.37(\mathrm{dd}, J=1.6,2.5 \mathrm{~Hz}, 1 \mathrm{H}), 7.15$ $(\mathrm{d}, J=1.6 \mathrm{~Hz}, 1 \mathrm{H}), 6.70(\mathrm{dd}, J=1.5,2.7 \mathrm{~Hz}, 1 \mathrm{H}), 6.23(\mathrm{dd}, J=$ $1.5,3.4 \mathrm{~Hz}, 1 \mathrm{H}), 6.10(\mathrm{dd}, J=2.7,3.4 \mathrm{~Hz}, 1 \mathrm{H}) ;{ }^{13} \mathrm{C} \mathrm{NMR}\left(\mathrm{CD}_{3} \mathrm{OD}\right.$, $100 \mathrm{MHz}) \delta 180.7,134.4,127.7,123.8,122.6,118.1,117.2,109.4$, 104.7; HRMS (ESI) calcd for $\mathrm{C}_{9} \mathrm{H}_{9} \mathrm{~N}_{2} \mathrm{O}(\mathrm{M}+\mathrm{H})^{+} 161.0709$, found 161.0713. Note: Two NH protons are not appearing under these conditions.

2',4'-Dimethyl-[2,3'-bipyrrole]-5'-carboxaldehyde (23). ${ }^{1} \mathrm{H}$ NMR $\left(\mathrm{DMSO}_{-1}, 400 \mathrm{MHz}\right) \delta 11.68(\mathrm{br} \mathrm{s}, 1 \mathrm{H}), 10.59$ (br s, $\left.1 \mathrm{H}\right), 9.51(\mathrm{~s}$, $1 \mathrm{H}), 6,76($ br s, $1 \mathrm{H}), 6.08($ br s, $1 \mathrm{H}), 5.94($ br s, $1 \mathrm{H}), 2.28(\mathrm{~s}, 3 \mathrm{H})$ $2.24(\mathrm{~s}, 3 \mathrm{H}) ;{ }^{13} \mathrm{C}$ NMR (DMSO- $\left.d_{6}, 100 \mathrm{MHz}\right) \delta 176.4,135.2,129.8$, $127.7,124.2,117.3,117.1,107.9,107.0,12.1,9.5$; HRMS (ESI) calcd for $\mathrm{C}_{11} \mathrm{H}_{13} \mathrm{~N}_{2} \mathrm{O}(\mathrm{M}+\mathrm{H})^{+}$189.1022, found 189.1026 .

4'-Methyl-[2,3'-bipyrrole]-5'-carboxaldehyde (24). ${ }^{1} \mathrm{H} \quad \mathrm{NMR}$ (DMSO- $\left.d_{6}, 600 \mathrm{MHz}\right) \delta 11.78($ br s, $1 \mathrm{H}), 10.78$ (br s, $\left.1 \mathrm{H}\right), 9.64$ $(\mathrm{s}, 1 \mathrm{H}), 7.33(\mathrm{~d}, J=3.0 \mathrm{~Hz}, 1 \mathrm{H}), 6.71(\mathrm{dd}, J=1.8,2.4 \mathrm{~Hz}, 1 \mathrm{H}), 6.10$ (dd, $J=1.8,3.0 \mathrm{~Hz}, 1 \mathrm{H}), 6.07(\mathrm{dd}, J=2.4,3.0 \mathrm{~Hz}, 1 \mathrm{H}), 2.41(\mathrm{~s}, 3 \mathrm{H})$; ${ }^{13} \mathrm{C}$ NMR (DMSO- $\left.d_{6}+\mathrm{CDCl}_{3}, 100 \mathrm{MHz}\right) \delta 176.2,128.7,125.8$, 124.5, 122.1, 118.1, 115.6, 107.1, 104.0, 8.9; HRMS (ESI) calcd for $\mathrm{C}_{10} \mathrm{H}_{11} \mathrm{~N}_{2} \mathrm{O}(\mathrm{M}+\mathrm{H})^{+}$175.0866, found 175.0871.

4'-Ethyl-[2,3'-bipyrrole]-5'-carboxaldehyde (25). ${ }^{1} \mathrm{H}$ NMR $\left(\right.$ DMSO- $\left.d_{6}, 600 \mathrm{MHz}\right) \delta 9.69(\mathrm{~s}, 1 \mathrm{H}), 7.40(\mathrm{~d}, J=2.7 \mathrm{~Hz}, 1 \mathrm{H})$, $6.70(\mathrm{dd}, J=1.7,2.7 \mathrm{~Hz}, 1 \mathrm{H}), 6.25(\mathrm{~d}, J=3.2 \mathrm{~Hz}, 1 \mathrm{H}), 6.16(\mathrm{dd}, J=$ 2.7, $3.2 \mathrm{~Hz}, 1 \mathrm{H}), 2.70(\mathrm{q}, J=7.3 \mathrm{~Hz}, 2 \mathrm{H}), 1.12(\mathrm{t}, J=7.3 \mathrm{~Hz}, 3 \mathrm{H})$; HRMS (ESI) calcd for $\mathrm{C}_{11} \mathrm{H}_{13} \mathrm{~N}_{2} \mathrm{O}(\mathrm{M}+\mathrm{H})^{+} 189.1022$, found 189.1027. Note: Two NH protons are not appearing under these conditions.

Synthesis of 26-31. Compounds 26 (276 mg, 55\%), 27 (266 mg, $57 \%), 28$ (296 mg, 63\%), 29 (346 mg, 68\%), 30 (346 mg, 67\%), and $31(385 \mathrm{mg}, 65 \%)$ were synthesized by the same procedure as described for 9 with modification of the reaction conditions for the deprotection of $\mathrm{N}$-triisopropylsilyl group. The crude material was dissolved in THF (10 mL), and TBAF (2 equiv) was added dropwise under an argon atmosphere. The resulting mixture was stirred at room temperature for $15 \mathrm{~min}$.

1',3,4-Trimethyl-[2,2'-bipyrrole]-5-carboxaldehyde (26). ${ }^{1} \mathrm{H}$ NMR $\left(\mathrm{CDCl}_{3}, 400 \mathrm{MHz}\right) \delta 9.62(\mathrm{~s}, 1 \mathrm{H}), 8.84(\mathrm{br} \mathrm{s}, 1 \mathrm{H}), 6.77(\mathrm{dd}, J=1.8$, $2.4 \mathrm{~Hz}, 1 \mathrm{H}), 6.28(\mathrm{dd}, J=1.8,3.7 \mathrm{~Hz}, 1 \mathrm{H}), 6.23(\mathrm{dd}, J=2.4,3.7 \mathrm{~Hz}$, $1 \mathrm{H}), 3.61(\mathrm{~s}, 3 \mathrm{H}), 2.33(\mathrm{~s}, 3 \mathrm{H}), 2.02(\mathrm{~s}, 3 \mathrm{H}) ;{ }^{13} \mathrm{C} \mathrm{NMR}\left(\mathrm{CDCl}_{3}, 100\right.$ $\mathrm{MHz}) \delta 176.8,131.8,129.6,129.0,124.3,124.2,120.4,111.3,108.4$, 34.8, 9.6, 9.0; HRMS (ESI) calcd for $\mathrm{C}_{12} \mathrm{H}_{14} \mathrm{NaN}_{2} \mathrm{O}(\mathrm{M}+\mathrm{Na})^{+}$ 225.0998 , found 225.1006 .

3,4-Dimethyl-[2,3'-bipyrrole]-5-carboxaldehyde (27). ${ }^{1} \mathrm{H} \quad \mathrm{NMR}$ $\left(\mathrm{CDCl}_{3}, 400 \mathrm{MHz}\right) \delta 9.52(\mathrm{~s}, 1 \mathrm{H}), 9.10(\mathrm{br} \mathrm{s}, 1 \mathrm{H}), 8.64(\mathrm{br} \mathrm{s}, 1 \mathrm{H})$, $7.12(\mathrm{~m}, 1 \mathrm{H}), 6.89(\mathrm{~m}, 1 \mathrm{H}), 6.48(\mathrm{~m}, 1 \mathrm{H}), 2.31(\mathrm{~s}, 3 \mathrm{H}), 2.15(\mathrm{~s}, 3 \mathrm{H})$; ${ }^{13} \mathrm{C}$ NMR $\left(\mathrm{CDCl}_{3}, 100 \mathrm{MHz}\right) \delta 175.4,134.3,133.3,127.9,119.1$, 117.1, 116.6, 115.5, 106.9, 9.8, 8.9; HRMS (ESI) calcd for $\mathrm{C}_{11} \mathrm{H}_{12} \mathrm{NaN}_{2} \mathrm{O}$ $(\mathrm{M}+\mathrm{Na})^{+} 189.1022$, found 189.1028 .

5-(Furan-2-yl)-3,4-dimethylpyrrole-2-carboxaldehyde (28). ${ }^{1} \mathrm{H}$ NMR $\left(\mathrm{CDCl}_{3}, 400 \mathrm{MHz}\right) \delta 9.63(\mathrm{~s}, 1 \mathrm{H}), 9.52(\mathrm{br} \mathrm{s}, 1 \mathrm{H}), 7.48(\mathrm{dd}$, $J=1.6,2.8 \mathrm{~Hz}, 1 \mathrm{H}), 6.64(\mathrm{dd}, J=1.6,3.6 \mathrm{~Hz}, 1 \mathrm{H}), 6.52(\mathrm{dd}, J=2.8$, $3.6 \mathrm{~Hz}, 1 \mathrm{H}), 2.30(\mathrm{~s}, 3 \mathrm{H}), 2.17(\mathrm{~s}, 3 \mathrm{H}) ;{ }^{13} \mathrm{C} \mathrm{NMR}\left(\mathrm{CDCl}_{3}, 100 \mathrm{MHz}\right)$ $\delta 176.8,146.5,142.1,132.1,128.6,128.0,117.9,111.9,107.8,9.6,8.6$; HRMS (ESI) calcd for $\mathrm{C}_{11} \mathrm{H}_{11} \mathrm{NaN}_{2} \mathrm{O}(\mathrm{M}+\mathrm{Na})^{+} 212.0682$, found 212.0689 . 
3,4-Dimethyl-5-(thiophen-2-yl)pyrrole-2-carboxaldehyde (29). ${ }^{1} \mathrm{H}$ NMR $\left(\mathrm{CDCl}_{3}, 400 \mathrm{MHz}\right) \delta 9.63(\mathrm{~s}, 1 \mathrm{H}), 9.53$ (br s, $\left.1 \mathrm{H}\right), 7.37$ (dd, $J=1.6,2.7 \mathrm{~Hz}, 1 \mathrm{H}), 7.34$ (dd, $J=1.6,3.5 \mathrm{~Hz}, 1 \mathrm{H}), 7.13$ (dd, $J=$ 2.7, $3.5 \mathrm{~Hz}, 1 \mathrm{H}), 2.33(\mathrm{~s}, 3 \mathrm{H}), 2.21(\mathrm{~s}, 3 \mathrm{H}) ;{ }^{13} \mathrm{C} \mathrm{NMR}\left(\mathrm{CDCl}_{3}, 100\right.$ $\mathrm{MHz}) \delta 176.8,133.6,132.6,131.4,128.9,127.8,125.7,124.2,118.9$, 9.9, 8.9; HRMS (ESI) calcd for $\mathrm{C}_{11} \mathrm{H}_{11} \mathrm{NaNOS}(\mathrm{M}+\mathrm{Na})^{+} 228.0454$, found 228.0459 .

3,4-Dimethyl-5-phenylpyrrole-2-carboxaldehyde (30). ${ }^{1} \mathrm{H}$ NMR $\left(\mathrm{CDCl}_{3}, 400 \mathrm{MHz}\right) \delta 9.64(\mathrm{~s}, 1 \mathrm{H}), 9.49(\mathrm{br} \mathrm{s}, 1 \mathrm{H}), 7.52(\mathrm{~m}, 2 \mathrm{H})$, $7.46(\mathrm{~m}, 2 \mathrm{H}), 7.39(\mathrm{~m}, 1 \mathrm{H}), 2.34(\mathrm{~s}, 3 \mathrm{H}), 2.17(\mathrm{~s}, 3 \mathrm{H}) ;{ }^{13} \mathrm{C}$ NMR $\left(\mathrm{CDCl}_{3}, 100 \mathrm{MHz}\right) \delta 176.9,137.0,132.6,131.7,129,0,128.9$ (2C), 128.2, 127.8 (2C), 118.6, 9.8, 9.0; HRMS (ESI) calcd for $\mathrm{C}_{13} \mathrm{H}_{13} \mathrm{NaNO}$ $(\mathrm{M}+\mathrm{Na})^{+} 222.0889$, found 222.0897 .

5-(Indol-2-yl)-3,4-dimethylpyrrole-2-carboxaldehyde (31). ${ }^{1} \mathrm{H}$ NMR (DMSO- $\left.d_{6}, 400 \mathrm{MHz}\right) \delta 11.43$ (br s, $\left.2 \mathrm{H}\right), 9.62(\mathrm{~s}, 1 \mathrm{H}), 7.44$ (m, 2H), $7.09(\mathrm{~m}, 2 \mathrm{H}), 6.82(\mathrm{~s}, 1 \mathrm{H}), 2.29(\mathrm{~s}, 3 \mathrm{H}), 2.21(\mathrm{~s}, 3 \mathrm{H}) ;{ }^{13} \mathrm{C}$ NMR $\left(\mathrm{CDCl}_{3}+\right.$ DMSO- $\left.d_{6}, 100 \mathrm{MHz}\right) \delta 177.1,136.1,130.9,129.6$, 129.2, 128.8, 128.3, 122.1, 120.2, 119.6, 118.4, 111.2, 101.5, 10.0, 8.5; HRMS (ESI) calcd for $\mathrm{C}_{15} \mathrm{H}_{15} \mathrm{~N}_{2} \mathrm{O}(\mathrm{M}+\mathrm{H})^{+}$239.1179, found 239.1188.

Representative Procedure for the Synthesis of 2-Ethylpyrrole (67a). To a stirred suspension of $\mathrm{LiAlH}_{4}(3.49 \mathrm{~g}, 91.74 \mathrm{mmol})$ in dry THF $(50 \mathrm{~mL})$ was added dropwise $66 \mathrm{a}(5.0 \mathrm{~g}, 45.87 \mathrm{mmol})$ in THF $(50 \mathrm{~mL})$ at $0{ }^{\circ} \mathrm{C}$. Then the resulting solution was heated to reflux overnight. The reaction was quenched with saturated solution of sodium sulfate. The insoluble solid was filtered off and washed with DCM $(100 \mathrm{~mL})$. Then the combined organic solution was concentrated under reduced pressure and the product was chromatographed on silica gel, with ethyl acetate/hexanes as eluent, to afford the desired product $67 \mathrm{a}(4.0 \mathrm{~g}, 92 \%)$.

2-Isobutylpyrrole (67b). Yield: $4.26 \mathrm{~g}$, 95\%. HRMS (ESI) calcd for $\mathrm{C}_{8} \mathrm{H}_{14} \mathrm{~N}(\mathrm{M}+\mathrm{H})^{+}$124.1121, found 124.1126.

Representative Procedure for the Synthesis of tert-Butyl 2Ethyl-pyrrole-1-carboxylate (68a). 4-Dimethylaminopyridine (DMAP; $257 \mathrm{mg}, 2.10 \mathrm{mmol}$ ) was added to a stirred solution of 67a $(2.0 \mathrm{~g}, 21.05 \mathrm{mmol})$ and di-tert-butyl dicarbonate $\left(\mathrm{Boc}_{2} \mathrm{O} ; 6.23 \mathrm{~g}\right.$, $27.36 \mathrm{mmol})$ in acetonitrile $(50 \mathrm{~mL})$, and the reaction was left to stir for $1 \mathrm{~h}$ at room temperature. Dichloromethane $(150 \mathrm{~mL})$ was added, and the solution was washed with water and brine and dried over anhydrous $\mathrm{Na}_{2} \mathrm{SO}_{4}$. The solvent was removed by rotary evaporation and the product was chromatographed on silica gel, with ethyl acetate/ hexanes as eluent, to afford the pure 68a (3.90 g, 95\%). HRMS (ESI) calcd for $\mathrm{C}_{11} \mathrm{H}_{18} \mathrm{NO}_{2}(\mathrm{M}+\mathrm{H})^{+}$196.1332, found 196.1335.

tert-Butyl 2-Isobutylpyrrole-1-carboxylate (68b). Yield: $3.40 \mathrm{~g}$, 94\%. ${ }^{1} \mathrm{H}$ NMR $\left(\mathrm{CDCl}_{3}, 400 \mathrm{MHz}\right) \delta 7.21(\mathrm{dd}, J=1.6,2.4 \mathrm{~Hz}, 1 \mathrm{H})$, $6.09(\mathrm{dd}, J=1.6,3.6 \mathrm{~Hz}, 1 \mathrm{H}), 5.95(\mathrm{dd}, J=2.4,3.6 \mathrm{~Hz}, 1 \mathrm{H}), 2.73(\mathrm{~d}$, $J=7.0 \mathrm{~Hz}, 2 \mathrm{H}), 1.93(\mathrm{~m}, 1 \mathrm{H}), 1.61(\mathrm{~s}, 9 \mathrm{H}), 0.94(\mathrm{~d}, J=6.3 \mathrm{~Hz}, 6 \mathrm{H})$; ${ }^{13} \mathrm{C} \mathrm{NMR}\left(\mathrm{CDCl}_{3}, 100 \mathrm{MHz}\right) \delta 149.6,135.1,120.9,112.3,109.7,83.1$, 37.8, 28.0 (3C), 27.7, 22.5 (2C): HRMS (ESI) calcd for $\mathrm{C}_{13} \mathrm{H}_{22} \mathrm{NO}_{2}$ $(\mathrm{M}+\mathrm{H})^{+} 224.1645$, found 224.1649 .

tert-Butyl 2,4-Dimethylpyrrole-1-carboxylate (68c). Yield: $3.77 \mathrm{~g}$, $92 \% .{ }^{1} \mathrm{H}$ NMR $\left(\mathrm{CDCl}_{3}, 400 \mathrm{MHz}\right) \delta 6.94(\mathrm{~s}, 1 \mathrm{H}), 5.80(\mathrm{~s}, 1 \mathrm{H}), 2.41$ $(\mathrm{s}, 3 \mathrm{H}), 2.02(\mathrm{~s}, 3 \mathrm{H}), 1.60(\mathrm{~s}, 9 \mathrm{H}) ;{ }^{13} \mathrm{C} \mathrm{NMR}\left(\mathrm{CDCl}_{3}, 100 \mathrm{MHz}\right) \delta$ 149.6, 131.6, 120.4, 117.5, 114.2, 82.8, 28.1 (3C), 15.4, 11.7; HRMS (ESI) calcd for $\mathrm{C}_{11} \mathrm{H}_{18} \mathrm{NO}_{2}(\mathrm{M}+\mathrm{H})^{+}$196.1332, found 196.1339.

tert-Butyl 3-Ethyl-2,4-dimethylpyrrole-1-carboxylate (68d). Yield: $3.26 \mathrm{~g}, 90 \% .{ }^{1} \mathrm{H}$ NMR $\left(\mathrm{CDCl}_{3}, 400 \mathrm{MHz}\right) \delta 6.96(\mathrm{~s}, 1 \mathrm{H}), 2.38(\mathrm{q}, J=$ $7.6 \mathrm{~Hz}, 2 \mathrm{H}), 2.37(\mathrm{~s}, 3 \mathrm{H}), 2.01(\mathrm{~s}, 3 \mathrm{H}), 1.61(\mathrm{~s}, 9 \mathrm{H}), 1.07(\mathrm{t}, J=7.6$ $\mathrm{Hz}, 3 \mathrm{H}$ ); HRMS (ESI) calcd for $\mathrm{C}_{13} \mathrm{H}_{22} \mathrm{NO}_{2}(\mathrm{M}+\mathrm{H})^{+}$224.1645, found 224.1653 .

Representative Procedure for the Synthesis of (1-(tertButoxycarbonyl)-5-ethylpyrrol-2-yl)boronic Acid (69a). To a stirred solution of 2,2,6,6-tetramethylpiperidine $(2.60 \mathrm{~g}, 18.46 \mathrm{mmol})$ in dry THF $(50 \mathrm{~mL})$ was added dropwise $n$-BuLi $(1.6 \mathrm{M}$ in pentane, $12.5 \mathrm{~mL}, 20.0 \mathrm{mmol})$ under an argon atmosphere at $-78{ }^{\circ} \mathrm{C}$. The reaction mixture was allowed to warm to $0{ }^{\circ} \mathrm{C}$ and maintained at that temperature for $30 \mathrm{~min}$. After cooling again to $-78{ }^{\circ} \mathrm{C}$, a solution of $68 \mathrm{a}(3.0 \mathrm{~g}, 15.38 \mathrm{mmol})$ in THF $(10 \mathrm{~mL})$ was added. The reaction mixture was stirred for $2 \mathrm{~h}$ at $-78^{\circ} \mathrm{C}$ prior to the addition of trimethyl borate $(7.92 \mathrm{~g}, 76.92 \mathrm{mmol})$. The solution was allowed to react at ambient temperature overnight. The reaction mixture was diluted with EtOAc $(200 \mathrm{~mL})$, washed with water and brine solution, and dried over anhydrous $\mathrm{Na}_{2} \mathrm{SO}_{4}$. The solvent was removed by rotary evaporation to furnish the desired product $69 \mathrm{a}(3.12 \mathrm{~g}, 85 \%)$ as a brown solid. The product 69a was carried forward into the next reaction without further purification. The products $69 \mathrm{~b}(1.82 \mathrm{~g}, 76 \%), 69 \mathrm{c}(1.59 \mathrm{~g}$, $65 \%)$, and $69 \mathrm{~d}(1.62 \mathrm{~g}, 68 \%)$ were also carried forward into the next reaction without further purification.

Synthesis of 32-35. Compounds 32 (403 mg, 75\%), 33 (467 mg, $77 \%), 34(1.59 \mathrm{~g}, 57 \%)$, and 35 (1.62 g, 55\%) were synthesized by the same procedure as described for 9 .

5'-Ethyl-3,4-dimethyl-[2,2'-bipyrrole]-5-carboxaldehyde (32). ${ }^{1} \mathrm{H}$ NMR (DMSO- $\left.d_{6}, 600 \mathrm{MHz}\right) \delta 10.99(\mathrm{~s}, 1 \mathrm{H}), 10.94$ (br s, $\left.1 \mathrm{H}\right), 9.46$ $(\mathrm{s}, 1 \mathrm{H}), 6.35($ br s, $1 \mathrm{H}), 5.89($ br s, $1 \mathrm{H}), 2.61(\mathrm{br} \mathrm{s}, 2 \mathrm{H}), 2.22(\mathrm{~s}, 3 \mathrm{H})$, $2.06(\mathrm{~s}, 3 \mathrm{H}), 1.21(\mathrm{br} \mathrm{s}, 3 \mathrm{H}) ;{ }^{13} \mathrm{C} \mathrm{NMR}\left(\mathrm{CDCl}_{3}+\mathrm{DMSO}_{6}, 150\right.$ $\mathrm{MHz}) \delta 175.0,135.6,131.8,130.9,127.5,122.0,115.3,108.9,106.0$, 20.3, 13.6, 9.9, 8.9; HRMS (ESI) calcd for $\mathrm{C}_{13} \mathrm{H}_{17} \mathrm{~N}_{2} \mathrm{O}(\mathrm{M}+\mathrm{H})^{+}$ 217.1335 , found 217.1348

5'-Isobutyl-3,4-dimethyl-[2,2'-bipyrrole]-5-carboxaldehyde (33). ${ }^{1} \mathrm{H}$ NMR $\left(\mathrm{CDCl}_{3}+\mathrm{DMSO}_{-} d_{6}, 400 \mathrm{MHz}\right) \delta 11.18$ (br s, $\left.1 \mathrm{H}\right), 10.92$ (br s, 1H), $9.24(\mathrm{~s}, 1 \mathrm{H}), 6.40(\mathrm{br} \mathrm{s}, 1 \mathrm{H}), 5.85(\mathrm{~s}, 1 \mathrm{H}), 2.41$ (d, $J=7.1$ $\mathrm{Hz}, 2 \mathrm{H}), 2.17(\mathrm{~s}, 3 \mathrm{H}), 2.04(\mathrm{~s}, 3 \mathrm{H}), 1.86(\mathrm{~m}, 1 \mathrm{H}), 0.85(\mathrm{~d}, J=6.4 \mathrm{~Hz}$, $6 \mathrm{H}) ;{ }^{13} \mathrm{C}$ NMR $\left(\mathrm{CDCl}_{3}+\mathrm{DMSO}-d_{6}, 150 \mathrm{MHz}\right) \delta 173.6,134.4,134.2$, 133.3, 127.5, 122.3, 116.8, 110.2, 107.9, 37.3, 29.1, 22.4 (2C), 10.3, 8.7; HRMS (ESI) calcd for $\mathrm{C}_{15} \mathrm{H}_{21} \mathrm{~N}_{2} \mathrm{O}(\mathrm{M}+\mathrm{H})^{+} 245.1648$, found 245.1660 .

3,3', 4, 5'-Tetramethyl-[2,2'-bipyrrole]-5-carbaldehyde (34). ${ }^{1} \mathrm{H}$ NMR $\left(\mathrm{CDCl}_{3}, 400 \mathrm{MHz}\right) \delta 9.52(\mathrm{~s}, 1 \mathrm{H}), 9.24(\mathrm{br} \mathrm{s}, 1 \mathrm{H}), 8.40(\mathrm{br} \mathrm{s}$, $1 \mathrm{H}), 5.84(\mathrm{~d}, J=2.6 \mathrm{~Hz}, 1 \mathrm{H}), 2.31(\mathrm{~s}, 6 \mathrm{H}), 2.16(\mathrm{~s}, 3 \mathrm{H}), 2.09(\mathrm{~s}, 3 \mathrm{H})$; ${ }^{13} \mathrm{C}$ NMR $\left(\mathrm{CDCl}_{3}, 100 \mathrm{MHz}\right) \delta 174.2,130.4,127.4,127.2,117.0$, 116.7, 116.6, 107.7 (2C), 11.6, 11.1, 8.6, 7.8; HRMS (ESI) calcd for $\mathrm{C}_{13} \mathrm{H}_{17} \mathrm{~N}_{2} \mathrm{O}(\mathrm{M}+\mathrm{H})^{+}$217.1335, found 217.1348.

4'-Ethyl-3,3',4,5'-tetramethyl-[2,2'-bipyrrole]-5-carboxaldehyde (35). HRMS (ESI) calcd for $\mathrm{C}_{15} \mathrm{H}_{21} \mathrm{~N}_{2} \mathrm{O}(\mathrm{M}+\mathrm{H})^{+} 245.1648$, found 245.1656.

Synthesis of (1-(tert-Butoxycarbonyl)-4-ethyl-pyrrol-2-yl)boronic Acid (71). Compound $71(1.81 \mathrm{~g}, 74 \%)$ was synthesized by the same procedure as described for 69 a. The product 71 was carried forward into the next reaction without further purification.

Synthesis of 4'-Ethyl-3,4-dimethyl-[2,2' -bipyrrole]-5-carboxaldehyde (36). Compound 36 (413 mg, 77\%) was synthesized by the same procedure as described for 9. ${ }^{1} \mathrm{H}$ NMR (DMSO- $d_{6}, 400 \mathrm{MHz}$ ) $\delta 11.26(\mathrm{br} \mathrm{s}, 1 \mathrm{H}), 10.75(\mathrm{br} \mathrm{s}, 1 \mathrm{H}), 9.48(\mathrm{~s}, 1 \mathrm{H}), 6.70(\mathrm{~s}, 1 \mathrm{H}), 6.35(\mathrm{~s}$, $1 \mathrm{H}), 2.45(\mathrm{q}, J=7.5 \mathrm{~Hz}, 2 \mathrm{H}), 2.22(\mathrm{~s}, 3 \mathrm{H}), 2.07(\mathrm{~s}, 3 \mathrm{H}), 1.15(\mathrm{t}, J=$ $7.5 \mathrm{~Hz}, 3 \mathrm{H}) ;{ }^{13} \mathrm{C}$ NMR (DMSO-d $\left.d_{6}, 100 \mathrm{MHz}\right) \delta 173.4,130.8,129.8$, 126.3, 125.6, 122.2, 122.0, 114.6, 107.4, 18.6, 14.0, 8.9, 7.3; HRMS (ESI) calcd for $\mathrm{C}_{13} \mathrm{H}_{17} \mathrm{~N}_{2} \mathrm{O}(\mathrm{M}+\mathrm{H})^{+} 217.1335$, found 217.1346 .

Synthesis of tert-Butyl 1-Formyl-4,5,6,7-tetrahydroisoindole2-carboxylate (72). Compound $72(3.17 \mathrm{~g}, 95 \%)$ was synthesized by the same procedure as described for $68 \mathbf{a} .{ }^{1} \mathrm{H}$ NMR $\left(\mathrm{CDCl}_{3}\right.$, $400 \mathrm{MHz}) \delta 10.38(\mathrm{~s}, 1 \mathrm{H}), 7.14(\mathrm{~s}, 1 \mathrm{H}), 2.88(\mathrm{t}, J=5.8 \mathrm{~Hz}, 2 \mathrm{H}), 2.52$ $(\mathrm{t}, J=5.6 \mathrm{~Hz}, 2 \mathrm{H}), 1.74(\mathrm{~m}, 4 \mathrm{H}), 1.69(\mathrm{~s}, 9 \mathrm{H}) ;{ }^{13} \mathrm{C} \mathrm{NMR}\left(\mathrm{CDCl}_{3}\right.$, $100 \mathrm{MHz}) \delta 183.4,148.7,137.3,129.1,123.8,122.7,84.8,28.0$ (3C), 24.2, 22.7, 22.6, 21.5; HRMS (ESI) calcd for $\mathrm{C}_{14} \mathrm{H}_{19} \mathrm{NaNO}_{3}(\mathrm{M}+\mathrm{Na})^{+}$ 272.1257 , found 272.1263

Synthesis of tert-Butyl 1-(Dimethoxymethyl)-4,5,6,7tetrahydroisoindole-2-carboxylate (73). A solution of aldehyde $72(2.0 \mathrm{~g}, 8.03 \mathrm{mmol})$, trimethyl orthoformate $(1.70 \mathrm{~g}, 16.06 \mathrm{mmol})$, and a catalytic amount $(30 \mathrm{mg})$ of $p$-toluenesulfonic acid (PTSA) in $\mathrm{MeOH}(20 \mathrm{~mL})$ was stirred at room temperature for $1 \mathrm{~h}$. The reaction mixture was diluted with $\mathrm{Et}_{2} \mathrm{O}(200 \mathrm{~mL})$ and washed with a solution of $\mathrm{NaHCO}_{3}$. The organic layer was washed with water and dried over anhydrous $\mathrm{Na}_{2} \mathrm{SO}_{4}$. The solvent was removed by rotary evaporation and the product was chromatographed on silica gel, with ethyl acetate/ hexanes as eluent, to afford the pure product $73(2.01 \mathrm{~g}, 85 \%)$. HRMS (ESI) calcd for $\mathrm{C}_{16} \mathrm{H}_{26} \mathrm{NO}_{4}(\mathrm{M}+\mathrm{H})^{+}$296.1856, found 296.1863.

Synthesis of (3-Formyl-4,5,6,7-tetrahydroisoindol-1-yl)boronic Acid (74). To a stirred solution of $73(1.2 \mathrm{~g}, 4.06 \mathrm{mmol})$ in THF $(10 \mathrm{~mL})$ was added triisopropyl borate $(1.14 \mathrm{~g}, 6.10 \mathrm{mmol})$. The solution was cooled to $0-5{ }^{\circ} \mathrm{C}$ in an ice bath, and lithium diisopropylamide (LDA; $2 \mathrm{~N}, 4 \mathrm{~mL}, 8.13 \mathrm{mmol}$ ) was added over 
$20 \mathrm{~min}$, and stirring was continued for an additional hour. The saturated ammonium chloride $(5 \mathrm{~mL})$ and $10 \%$ aqueous potassium bisulfate solution $(50 \mathrm{~mL})$ were added to adjust to $\mathrm{pH} 2$, followed by stirring at room temperature for $2 \mathrm{~h}$. The reaction mixture was diluted with EtOAc $(200 \mathrm{~mL})$, washed with brine solution, and dried over anhydrous $\mathrm{Na}_{2} \mathrm{SO}_{4}$. The solvent was removed by rotary evaporation to furnish the desired product $74(738 \mathrm{mg}, 94 \%)$ as an orange solid. The product 74 was carried forward into the next reaction without further purification.

Synthesis of 3-(Imidazol-2-yl)-4,5,6,7-tetrahydroisoindole-1carboxaldehyde (37). Compound 37 (478 mg, 65\%) was synthesized by the same procedure as described for 9. ${ }^{1} \mathrm{H}$ NMR $\left(\mathrm{DMSO}^{-} d_{6}, 400 \mathrm{MHz}\right) \delta 12.02(\mathrm{~s}, 1 \mathrm{H}), 11.68(\mathrm{br} \mathrm{s}, 1 \mathrm{H}), 9.53(\mathrm{~s}, 1 \mathrm{H})$, 7.26 (br s, $1 \mathrm{H}), 7.07$ (br s, $1 \mathrm{H}), 2.79(\mathrm{~m}, 4 \mathrm{H}), 1.72(\mathrm{~m}, 4 \mathrm{H}) ;{ }^{13} \mathrm{C}$ NMR $\left(\mathrm{CDCl}_{3}+\right.$ DMSO- $\left.d_{6}, 100 \mathrm{MHz}\right) \delta 176.9,139.6,132.5,129.3$, 127.3, 126.2, 120.7, 117.2, 22.8, 22.6, 22.3, 20.9; HRMS (ESI) calcd for $\mathrm{C}_{12} \mathrm{H}_{14} \mathrm{~N}_{3} \mathrm{O}(\mathrm{M}+\mathrm{H})^{+}$216.1131, found 216.1136.

Synthesis of 1-Methyl-4,5,6,7-tetrahydroisoindole (77). To a stirred suspension of $\mathrm{LiAlH}_{4}(1.57 \mathrm{~g}, 41.45 \mathrm{mmol})$ in dry THF $(50 \mathrm{~mL})$ was added dropwise $53(2.0 \mathrm{~g}, 10.36 \mathrm{mmol})$ in THF $(50 \mathrm{~mL})$ at $0{ }^{\circ} \mathrm{C}$. Then the resulting solution was stirred at the same temperature for an additional $3 \mathrm{~h}$ and heated to reflux overnight. The reaction was quenched with saturated solution of sodium sulfate. The insoluble solid was filtered off and washed with DCM $(100 \mathrm{~mL})$. Then the combined organic solution was concentrated under reduced pressure and the product was chromatographed on silica gel, with ethyl acetate/hexanes as eluent, to afford the desired product $77(1.19 \mathrm{~g}$, $85 \%) .{ }^{1} \mathrm{H}$ NMR $\left(\mathrm{CDCl}_{3}, 400 \mathrm{MHz}\right) \delta 7.61(\mathrm{br} \mathrm{s}, 1 \mathrm{H}), 6.47(\mathrm{~d}, J=2.8$ $\mathrm{Hz}, 1 \mathrm{H}), 2.71(\mathrm{t}, J=5.8 \mathrm{~Hz}, 2 \mathrm{H}), 2.60(\mathrm{t}, J=6.0 \mathrm{~Hz}, 2 \mathrm{H}), 1.90(\mathrm{~s}$, $3 \mathrm{H}), 1.87(\mathrm{~m}, 4 \mathrm{H}) ;{ }^{13} \mathrm{C} \mathrm{NMR}\left(\mathrm{CDCl}_{3}, 100 \mathrm{MHz}\right) \delta 121.9,120.1$, 115.5, 110.7, 24.2 (2C), 22.3, 21.5, 10.9; HRMS (ESI) calcd for $\mathrm{C}_{9} \mathrm{H}_{14} \mathrm{~N}(\mathrm{M}+\mathrm{H})^{+}$136.1121, found 136.1117 .

Synthesis of 3-Methyl-4,5,6,7-tetrahydroisoindole-1-carboxaldehyde (38). Compound 38 (917 mg, 76\%) was synthesized by the same procedure as described for 55. ${ }^{1} \mathrm{H}$ NMR $\left(\mathrm{CDCl}_{3}, 400 \mathrm{MHz}\right) \delta$ $10.10($ br s, $1 \mathrm{H}), 9.37(\mathrm{~s}, 1 \mathrm{H}), 2.82(\mathrm{t}, J=5.8 \mathrm{~Hz}, 2 \mathrm{H}), 2.41(\mathrm{t}, J=6.0$ $\mathrm{Hz}, 2 \mathrm{H}), 2.23(\mathrm{~s}, 3 \mathrm{H}), 1.78(\mathrm{~m}, 4 \mathrm{H}) ;{ }^{13} \mathrm{C} \mathrm{NMR}\left(\mathrm{CDCl}_{3}, 100 \mathrm{MHz}\right) \delta$ 175.0, 135.4, 135.1, 126.5, 120.2, 23.3, 22.8, 21.0, 20.8, 11.3; HRMS (ESI) calcd for $\mathrm{C}_{10} \mathrm{H}_{14} \mathrm{NO}(\mathrm{M}+\mathrm{H})^{+} 164.1070$, found 164.1065.

Synthesis of Bis(3-ethyl-4-methyl-1 H-pyrrol-2-yl)methane (79). Compound $79(1.13 \mathrm{~g}, 92 \%)$ was synthesized by the same procedure as described for $54 .{ }^{1} \mathrm{H}$ NMR $\left(\mathrm{CDCl}_{3}, 400 \mathrm{MHz}\right) \delta 7.25$ (br s, $2 \mathrm{H}), 6.26(\mathrm{t}, J=1.2 \mathrm{~Hz}, 2 \mathrm{H}), 3.73(\mathrm{~s}, 2 \mathrm{H}), 2.36(\mathrm{q}, J=7.5 \mathrm{~Hz}$, $4 \mathrm{H}), 1.97(\mathrm{~s}, 6 \mathrm{H}), 1.02(\mathrm{t}, J=7.5 \mathrm{~Hz}, 6 \mathrm{H})$; HRMS (ESI) calcd for $\mathrm{C}_{15} \mathrm{H}_{23} \mathrm{~N}_{2}(\mathrm{M}+\mathrm{H})^{+}$231.1856, found 231.1861.

Synthesis of $5,5^{\prime}$-Methylenebis(4-ethyl-3-methyl- $1 \mathrm{H}$-pyrrole2-carbaldehyde) (39). Compound 39 (907 mg, 73\%) was synthesized by the same procedure as described for $55 .{ }^{1} \mathrm{H} \mathrm{NMR}\left(\mathrm{CDCl}_{3}\right.$, $400 \mathrm{MHz}) \delta 11.46(\mathrm{br} \mathrm{s}, 2 \mathrm{H}), 9.48(\mathrm{~s}, 2 \mathrm{H}), 3.86(\mathrm{~s}, 2 \mathrm{H}), 2.31(\mathrm{q}, J=$ $7.4 \mathrm{~Hz}, 4 \mathrm{H}), 2.18(\mathrm{~s}, 6 \mathrm{H}), 0.81(\mathrm{t}, J=7.5 \mathrm{~Hz}, 6 \mathrm{H}) ;{ }^{13} \mathrm{C} \mathrm{NMR}\left(\mathrm{CDCl}_{3}\right.$, $100 \mathrm{MHz}) \delta 176.5,134.2,130.0,127.9,123.7,22.4,16.3,14.9,8.4$ (dimer); HRMS (ESI) calcd for $\mathrm{C}_{17} \mathrm{H}_{23} \mathrm{~N}_{2} \mathrm{O} 2(\mathrm{M}+\mathrm{H})^{+}$287.1786, found 287.1782 .

Representative Procedure for the Synthesis of Prodiginine (85). To a stirred solution of $6(250 \mathrm{mg}, 1.31 \mathrm{mmol})$ and 2,4dialkylpyrrole $(80 ; 829 \mathrm{mg}, 2.63 \mathrm{mmol})$ in anhydrous methanol $(50 \mathrm{~mL})$ was added methanolic $2 \mathrm{~N} \mathrm{HCl}$ (catalytic amount). The resulting brightly colored solution was stirred for $5 \mathrm{~h}$ at room temperature. The methanol was removed under reduced pressure and the product was chromatographed on neutral alumina, with ethyl acetate/ hexanes as eluent, to afford the desired prodiginine analogue $85 \cdot \mathrm{HCl}$ (468 mg, 68\%) as a bright red compound. ${ }^{1} \mathrm{H}$ NMR $\left(\mathrm{CDCl}_{3}, 400\right.$ $\mathrm{MHz}) \delta 12.85($ br s, $1 \mathrm{H}), 12.81($ br s, $1 \mathrm{H}), 12.65(\mathrm{br} \mathrm{s}, 1 \mathrm{H}), 7.30(\mathrm{~d}$, $J=8.1 \mathrm{~Hz}, 2 \mathrm{H}), 7.26(\mathrm{~m}, 5 \mathrm{H}), 7.06(\mathrm{~d}, J=8.1 \mathrm{~Hz}, 2 \mathrm{H}), 7.01(\mathrm{~s}, 1 \mathrm{H})$, $6.97(\mathrm{~m}, 1 \mathrm{H}), 6.38(\mathrm{~m}, 1 \mathrm{H}), 6.09(\mathrm{~d}, J=1.9 \mathrm{~Hz}, 1 \mathrm{H}), 5.87(\mathrm{~d}, J=1.6$ $\mathrm{Hz}, 1 \mathrm{H}), 4.23$ (s, $2 \mathrm{H}), 4.00$ (s, 3H), 3.93 (s, 2H); ${ }^{13} \mathrm{C} \mathrm{NMR}\left(\mathrm{CDCl}_{3}\right.$, $100 \mathrm{MHz}) \delta 166.2,149.1,148.8,141.0,138.3,136.4,132.5,132.2$, 130.5 (2C), 129.8 (2C), 128.7 (4C), 127.9, 123.9, 122.1, 121.7, 118.3, 113.4, 112.9, 112.2, 93.1, 58.9, 33.8, 31.9; HRMS (ESI) calcd for
$\mathrm{C}_{28} \mathrm{H}_{24} \mathrm{Cl}_{2} \mathrm{~N}_{3} \mathrm{O}(\mathrm{M}+\mathrm{H})^{+}$488.1291, found 488.1284; IR (KBr) $v_{\max }$ $3320,3010,2845,1510,1045,742 \mathrm{~cm}^{-1}$.

Synthesis of $5^{\prime}$-((3,5-Bis(4-chlorobenzyl)-1-methylpyrrol-2yl)methylene)-4'-methoxy-1-methyl-2,2'-bipyrrole (87). To a stirred solution of prodiginine $85(50 \mathrm{mg}, 0.10 \mathrm{mmol})$ in DMF $(10 \mathrm{~mL})$ was added $\mathrm{NaH}(10 \mathrm{mg}, 0.41 \mathrm{mmol})$ at $0{ }^{\circ} \mathrm{C}$. The resulting bright red suspension was stirred for $10 \mathrm{~min}$, and methyl iodide $(58 \mathrm{mg}, 0.41 \mathrm{mmol})$ was added at $0{ }^{\circ} \mathrm{C}$ and stirred for additional $30 \mathrm{~min}$. The reaction mixture was warmed to room temperature and gradually poured into ice cold water and extracted with ethyl acetate $(3 \times 30 \mathrm{~mL})$. The combined organic layers were washed with water and dried over anhydrous $\mathrm{Na}_{2} \mathrm{SO}_{4}$. The solvent was evaporated under reduced pressure and the product was chromatographed on neutral alumina, with ethyl acetate/hexanes as eluent, to afford the desired prodiginine $87(46 \mathrm{mg}, 85 \%) .{ }^{1} \mathrm{H}$ NMR $\left(\mathrm{CDCl}_{3}, 400 \mathrm{MHz}\right) \delta 7.24(\mathrm{~d}$, $J=8.3 \mathrm{~Hz}, 2 \mathrm{H}), 7.18(\mathrm{~d}, J=8.4 \mathrm{~Hz}, 2 \mathrm{H}), 7.11(\mathrm{~d}, J=8.4 \mathrm{~Hz}, 2 \mathrm{H})$, $7.06(\mathrm{~d}, J=8.3 \mathrm{~Hz}, 2 \mathrm{H}), 6.84(\mathrm{~s}, 1 \mathrm{H}), 6.74(\mathrm{br} \mathrm{s}, 1 \mathrm{H}), 6.68(\mathrm{dd}, J=$ $1.5,3.8 \mathrm{~Hz}, 1 \mathrm{H}), 6.17(\mathrm{dd}, J=2.6,3.7 \mathrm{~Hz}, 1 \mathrm{H}), 5.92(\mathrm{~s}, 1 \mathrm{H}), 5.75(\mathrm{~s}$, $1 \mathrm{H}), 4.25(\mathrm{~s}, 2 \mathrm{H}), 3.96(\mathrm{~s}, 3 \mathrm{H}), 3.90(\mathrm{~s}, 3 \mathrm{H}), 3.89(\mathrm{~s}, 2 \mathrm{H}), 3.63(\mathrm{~s}$, $3 \mathrm{H}) ;{ }^{13} \mathrm{C}$ NMR $\left(\mathrm{CDCl}_{3}, 100 \mathrm{MHz}\right) \delta 167.8,161.2,142.1,140.7$, $136.9,132.4,131.6,130.1$ (3C), 129.8 (2C), 129.3, 128.8, 128.7 (3C), 127.8 (2C), 127.2, 115.3, 113.5, 111.7, 108.4, 96.9, 58.4, 37.5, 33.0, 32.7, 29.7; HRMS (ESI) calcd for $\mathrm{C}_{30} \mathrm{H}_{28} \mathrm{Cl}_{2} \mathrm{~N}_{3} \mathrm{O}(\mathrm{M}+\mathrm{H})^{+}$516.1604, found 516.1607 .

Representative Procedure for the Synthesis of Tambjamine (99). To a stirred solution of $6(100 \mathrm{mg}, 0.52 \mathrm{mmol})$ and $n$-butylamine $(77 \mathrm{mg}, 1.05 \mathrm{mmol})$ in anhydrous methanol $(10 \mathrm{~mL})$ was added methanolic $2 \mathrm{~N} \mathrm{HCl}$ (catalytic amount). The resulting pale yellow colored solution was stirred at refluxing temperature for $5 \mathrm{~h}$, and the solvent was removed under reduced pressure. The crude solid was dissolved in EtOAc $(50 \mathrm{~mL})$ and washed with $2 \mathrm{~N} \mathrm{HCl}(2 \times 10 \mathrm{~mL})$. The organic layer was dried over anhydrous $\mathrm{Na}_{2} \mathrm{SO}_{4}$. The solvent was removed under reduced pressure and the product was chromatographed on neutral alumina, with ethyl acetate/hexanes as eluent, to afford the desired tambjamine $99(117 \mathrm{mg}, 91 \%)$ as a yellow solid. ${ }^{1} \mathrm{H}$ NMR $\left(\mathrm{CDCl}_{3}, 400 \mathrm{MHz}\right) \delta 7.26(\mathrm{~s}, 1 \mathrm{H}), 6.98(\mathrm{dd}, J=1.3,2.7 \mathrm{~Hz}$, $1 \mathrm{H}), 6.67(\mathrm{dd}, J=1.3,3.6 \mathrm{~Hz}, 1 \mathrm{H}), 6.20(\mathrm{dd}, J=2.7,3.6 \mathrm{~Hz}, 1 \mathrm{H}), 5.87$ (s, $1 \mathrm{H}), 3.84(\mathrm{~s}, 3 \mathrm{H}), 3.41(\mathrm{t}, J=7.1 \mathrm{~Hz}, 2 \mathrm{H}), 1.67(\mathrm{~m}, 2 \mathrm{H}), 1.37(\mathrm{~m}$, $2 \mathrm{H}), 0.89(\mathrm{t}, J=7.3 \mathrm{~Hz}, 3 \mathrm{H}) ;{ }^{13} \mathrm{C} \mathrm{NMR}\left(\mathrm{CDCl}_{3}, 100 \mathrm{MHz}\right) \delta 163.7$, 142.2 , 140.3, 124.0, 122.7, 113.1, 110.8, 110.7, 91.1, 58.5, 50.7, 32.2, 19.7, 13.6; HRMS (ESI) calcd for $\mathrm{C}_{14} \mathrm{H}_{20} \mathrm{~N}_{3} \mathrm{O}(\mathrm{M}+\mathrm{H})^{+}$246.1601, found 246.1605. IR (KBr) $v_{\max } 3299,2936,1420,1175,722 \mathrm{~cm}^{-1}$.

Representative Procedure for the Synthesis of $\mathrm{N}$-(Adamantan1-yl)-2-(((oxoboranyl)methylene)amino)acetamide (188). To a stirred solution of $44(2.0 \mathrm{~g}, 11.43 \mathrm{mmol})$ in a mixture of THF $(25 \mathrm{~mL})$ and $\mathrm{CH}_{2} \mathrm{Cl}_{2}(25 \mathrm{~mL})$ were added 1-adamantylamine (2.07 g, $13.71 \mathrm{mmol})$, DMAP (348 $\mathrm{mg}, 2.85 \mathrm{mmol})$, and $\mathrm{N}$-(3dimethylaminopropyl)- $N^{\prime}$-ethylcarbodiimide hydrochloride $(\mathrm{EDCl}, 2.62 \mathrm{~g}, 13.71 \mathrm{mmol})$. The reaction mixture was stirred at room temperature for $4 \mathrm{~h}$. The reaction was quenched with saturated aqueous $\mathrm{NH}_{4} \mathrm{Cl}$ solution $(50 \mathrm{~mL})$ and extracted with ethyl acetate $(3 \times 100 \mathrm{~mL})$. The combined organic phases were washed with brine and dried over anhydrous $\mathrm{Na}_{2} \mathrm{SO}_{4}$. The solvent was removed under reduced pressure and the product was chromatographed on neutral alumina, with ethyl acetate/hexanes as eluent, to afford the desired product $188(2.99 \mathrm{~g}, 85 \%) .{ }^{1} \mathrm{H}$ NMR $\left(\mathrm{CDCl}_{3}, 400 \mathrm{MHz}\right) \delta 6.01$ (br s, $1 \mathrm{H}), 5.52(\mathrm{br} \mathrm{s}, 1 \mathrm{H}), 3.64(\mathrm{~d}, J=4.7 \mathrm{~Hz}, 2 \mathrm{H}), 2.03(\mathrm{~m}, 3 \mathrm{H}), 1.96(\mathrm{~d}$, $J=2.9 \mathrm{~Hz}, 6 \mathrm{H}), 1.64(\mathrm{~m}, 6 \mathrm{H}), 1.41(\mathrm{~s}, 9 \mathrm{H})$; HRMS (ESI) calcd for $\mathrm{C}_{17} \mathrm{H}_{29} \mathrm{~N}_{2} \mathrm{O}_{3}(\mathrm{M}+\mathrm{H})^{+}$309.2173, found 309.2180.

Representative Procedure for the Synthesis of $\mathrm{N}$-(Adamantan1-yl)-2-aminoacetamide (189). Compound 188 (2.5 g, $8.11 \mathrm{mmol})$ was dissolved in $20 \mathrm{~mL}$ of trifluoroacetic acid/water (1:1) and stirred at room temperature for $3 \mathrm{~h}$. The reaction mixture was neutralized with $2 \mathrm{~N} \mathrm{NaOH}$ and extracted with ethyl acetate $(3 \times 100 \mathrm{~mL})$. The combined organic layers were washed with brine and dried over anhydrous $\mathrm{Na}_{2} \mathrm{SO}_{4}$. The solvent was removed under reduced pressure to obtain the pure product $189(1.60 \mathrm{~g}, 95 \%)$ as a white solid. ${ }^{1} \mathrm{H}$ $\operatorname{NMR}\left(\mathrm{CDCl}_{3}, 400 \mathrm{MHz}\right) \delta 6.88(\mathrm{br} \mathrm{s}, 1 \mathrm{H}), 3.20(\mathrm{~s}, 2 \mathrm{H}), 2.06(\mathrm{br} \mathrm{s}$, $3 \mathrm{H}), 1.97(\mathrm{~d}, J=2.8 \mathrm{~Hz}, 6 \mathrm{H}), 1.70(\mathrm{~m}, 6 \mathrm{H})$; HRMS (ESI) calcd for 
$\mathrm{C}_{12} \mathrm{H}_{21} \mathrm{~N}_{2} \mathrm{O}(\mathrm{M}+\mathrm{H})^{+}$209.1648, found 209.1646. Note: Two $\mathrm{NH}$ protons are not appearing under these conditions.

Synthesis of $\mathrm{N}$-(2-((Adamantan-1-yl)amino)-2-oxoethyl)pyrrole-2-carboxamide (190). Compound 190 (1.09 g, 81\%) was synthesized by the same procedure as described for 188. ${ }^{1} \mathrm{H}$ NMR $\left(\mathrm{CDCl}_{3}, 400 \mathrm{MHz}\right) \delta 9.83(\mathrm{br} \mathrm{s}, 1 \mathrm{H}), 7.21(\mathrm{t}, J=5.3 \mathrm{~Hz} 1 \mathrm{H}), 6.85(\mathrm{~m}$, $1 \mathrm{H}), 6.69(\mathrm{~m}, 1 \mathrm{H}), 6.16(\mathrm{~m}, 1 \mathrm{H}), 6.08(\mathrm{~s}, 1 \mathrm{H}), 3.90(\mathrm{~d}, J=5.3 \mathrm{~Hz}$, $2 \mathrm{H}), 1.99(\mathrm{br} \mathrm{s}, 3 \mathrm{H}), 1.92(\mathrm{~d}, J=2.6 \mathrm{~Hz}, 6 \mathrm{H}), 1.59(\mathrm{~m}, 6 \mathrm{H}) ;{ }^{13} \mathrm{C}$ NMR $\left(\mathrm{CDCl}_{3}+\mathrm{CD}_{3} \mathrm{OD}, 100 \mathrm{MHz}\right) \delta 169.1,162.4,124.9,122.2$, 111.2, 109.5, 51.0, 43.2, 42.2 (3C), 36.2 (3C), 29.4 (3C); HRMS (ESI) calcd for $\mathrm{C}_{17} \mathrm{H}_{23} \mathrm{NaN}_{3} \mathrm{O}_{2}(\mathrm{M}+\mathrm{Na})^{+} 324.1682$, found 324.1693 .

Synthesis of $\boldsymbol{N}^{1}-\left(\left(\right.\right.$ Pyrrol-2-yl)methyl)- $\boldsymbol{N}^{2}$-(adamantan-1-yl)ethane-1,2-diamine (191). Compound 191 (186 mg, 82\%) was synthesized by the same procedure as described for $67 \mathrm{a} .{ }^{1} \mathrm{H}$ NMR $\left(\mathrm{CDCl}_{3}, 400 \mathrm{MHz}\right) \delta 9.52(\mathrm{br} \mathrm{s}, 1 \mathrm{H}), 6.74(\mathrm{dd}, J=1.9,2.7 \mathrm{~Hz}, 1 \mathrm{H})$, $6.11(\mathrm{dd}, J=3.0,5.6 \mathrm{~Hz}, 1 \mathrm{H}), 6.02(\mathrm{~d}, J=1.9 \mathrm{~Hz}, 1 \mathrm{H}), 3.80(\mathrm{~s}, 2 \mathrm{H})$, 3.00 (br s, $2 \mathrm{H}), 2.76(\mathrm{~m}, 4 \mathrm{H}), 2.08(\mathrm{br} \mathrm{s}, 3 \mathrm{H}), 1.69-1.60(\mathrm{~m}, 12 \mathrm{H})$; ${ }^{13} \mathrm{C} \mathrm{NMR}\left(\mathrm{CDCl}_{3}, 100 \mathrm{MHz}\right) \delta 130.1,117.5,107.8,106.4,51.5,48.9$, 46.1, 42.1 (3C), 39.4, 36.5 (3C), 29.5 (3C); HRMS (ESI) calcd for $\mathrm{C}_{17} \mathrm{H}_{28} \mathrm{~N}_{3}(\mathrm{M}+\mathrm{H})^{+}$274.2278, found 274.2287.

Synthesis of 3-(Pyrrol-2-yl)acrylic Acid Methyl Ester (192). To a stirred suspension of $\mathrm{NaH}(910 \mathrm{mg}, 37.89 \mathrm{mmol})$ in $50 \mathrm{~mL}$ of anhydrous dimethoxyethane at $0{ }^{\circ} \mathrm{C}$ was added dropwise methyl diethylphosphonoacetate $(7.96 \mathrm{~g}, 37.89 \mathrm{mmol})$. The reaction mixture was stirred at $0{ }^{\circ} \mathrm{C}$ for $30 \mathrm{~min}$ and then allowed to warm to room temperature. Pyrrole-2-carboxaldehyde (40; $3.0 \mathrm{~g}, 31.58 \mathrm{mmol}$ ) was added, and the reaction mixture was stirred for additional $4 \mathrm{~h}$. The reaction was quenched with ice-water and extracted with ethyl acetate $(3 \times 50 \mathrm{~mL})$. The combined organic layer was washed with brine and dried over anhydrous $\mathrm{Na}_{2} \mathrm{SO}_{4}$. The solvent was evaporated under reduced pressure and the product was chromatographed on silica gel, with ethyl acetate/hexanes as eluent, to afford the pure product 192 $(3.72 \mathrm{~g}, 78 \%) . R_{f}$ value of the product 192 is similar to the starting material 40; the visualization of the product was black spot on TLC after applying the iodine vapor. ${ }^{1} \mathrm{H}$ NMR $\left(\mathrm{CDCl}_{3}, 600 \mathrm{MHz}\right) \delta 9.26$ (br s, $1 \mathrm{H}), 7.61(\mathrm{~d}, J=15.9 \mathrm{~Hz}, 1 \mathrm{H}), 6.94(\mathrm{~d}, J=1.4 \mathrm{~Hz}, 1 \mathrm{H}), 6.58(\mathrm{~s}$, $1 \mathrm{H}), 6.29(\mathrm{~d}, J=3.6 \mathrm{~Hz}, 1 \mathrm{H}), 6.10(\mathrm{~d}, J=15.9 \mathrm{~Hz}, 1 \mathrm{H}), 3.80(\mathrm{~s}, 3 \mathrm{H})$. HRMS (ESI) calcd for $\mathrm{C}_{8} \mathrm{H}_{10} \mathrm{NO}_{2}(\mathrm{M}+\mathrm{H})^{+} 152.0706$, found 152.0710 .

Synthesis of 3-(Pyrrol-2-yl)acrylic Acid (193). To a stirred suspension of $192(2.0 \mathrm{~g}, 13.24 \mathrm{mmol})$ in a mixture of THF $(50 \mathrm{~mL})$ and water $(60 \mathrm{~mL})$ was added $\mathrm{LiOH} \cdot \mathrm{H}_{2} \mathrm{O}(1.66 \mathrm{~g}, 39.73 \mathrm{mmol})$. The reaction mixture was stirred at $60{ }^{\circ} \mathrm{C}$ for $12 \mathrm{~h}$ after which it was cooled to $0{ }^{\circ} \mathrm{C}$ and washed with ethyl acetate $(3 \times 30 \mathrm{~mL})$. The aqueous layer was carefully acidified to $\mathrm{pH} 2$ with $2 \mathrm{~N} \mathrm{HCl}$ and extracted with ethyl acetate $(3 \times 50 \mathrm{~mL})$. The combined extracts were dried over anhydrous $\mathrm{Na}_{2} \mathrm{SO}_{4}$ and concentrated under reduced pressure to give the pure product $193\left(1.74 \mathrm{~g} \mathrm{96 \% ).}{ }^{1} \mathrm{H}\right.$ NMR $\left(\mathrm{CD}_{3} \mathrm{OD}, 600 \mathrm{MHz}\right) \delta 7.51(\mathrm{~d}, J=15.8 \mathrm{~Hz}, 1 \mathrm{H}), 6.91(\mathrm{dd}, J=1.1,2.3$ $\mathrm{Hz}, 1 \mathrm{H}), 6.49(\mathrm{dd}, J=1.1,3.5 \mathrm{~Hz}, 1 \mathrm{H}), 6.18(\mathrm{dd}, J=2.2,4.9 \mathrm{~Hz}, 1 \mathrm{H})$, $6.04(\mathrm{~d}, J=15.8 \mathrm{~Hz}, 1 \mathrm{H})$; HRMS (ESI) calcd for $\mathrm{C}_{7} \mathrm{H}_{7} \mathrm{NaNO}_{2}(\mathrm{M}+$ $\mathrm{Na})^{+} 160.0369$, found 160.0363 . Note: $\mathrm{NH}$ and $\mathrm{COOH}$ protons are not appearing under these conditions.

Synthesis of $\mathrm{N}$-(2-Adamantan-1-yl)amino)-2-oxoethyl)-3(pyrrol-2-yl)acrylamide (194). Compound 194 (2.02 g, 85\%) was synthesized by the same procedure as described for $188 .{ }^{1} \mathrm{H}$ NMR $\left(\right.$ DMSO- $\left.d_{6}, 600 \mathrm{MHz}\right) \delta 11.34(\mathrm{~s}, 1 \mathrm{H}), 7.95(\mathrm{t}, J=5.8 \mathrm{~Hz}, 1 \mathrm{H}), 7.27$ $(\mathrm{d}, J=15.7 \mathrm{~Hz}, 1 \mathrm{H}), 7.26(\mathrm{~s}, 1 \mathrm{H}), 6.91(\mathrm{dd}, J=2.4,3.7 \mathrm{~Hz}, 1 \mathrm{H}), 6.41$ $(\mathrm{s}, 1 \mathrm{H}), 6.26(\mathrm{~d}, J=15.7 \mathrm{~Hz}, 1 \mathrm{H}), 6.12(\mathrm{dd}, J=2.4,5.6 \mathrm{~Hz}, 1 \mathrm{H}), 3.71$ $(\mathrm{d}, J=5.8 \mathrm{~Hz}, 2 \mathrm{H}), 1.99(\mathrm{~s}, 3 \mathrm{H}), 1.92(\mathrm{~d}, J=2.7 \mathrm{~Hz}, 6 \mathrm{H}), 1.61(\mathrm{~m}$, $6 \mathrm{H}) ;{ }^{13} \mathrm{C}$ NMR (DMSO-d $\left.d_{6}, 100 \mathrm{MHz}\right) \delta 167.9,165.9,129.8,128.5$, 121.6, 114.9, 111.5, 109.5, 50.7, 42.5, 41.0 (3C), 36.0 (3C), 28.8 (3C); HRMS (ESI) calcd for $\mathrm{C}_{19} \mathrm{H}_{25} \mathrm{NaN}_{3} \mathrm{O}_{2}(\mathrm{M}+\mathrm{Na})^{+} 350.1839$, found 350.1853.

Representative Procedure for the Synthesis of 195 . To a stirred solution of $194(500 \mathrm{mg}, 1.52 \mathrm{mmol})$ in methanol $(10 \mathrm{~mL})$ at room temperature was added $\mathrm{NiCl}_{2} \cdot 6 \mathrm{H}_{2} \mathrm{O}(180 \mathrm{mg}, 0.76 \mathrm{mmol})$. When the clear solution acquired a greenish color, the whole reaction mixture was brought to $0{ }^{\circ} \mathrm{C}$ and $\mathrm{NaBH}_{4}(85 \mathrm{mg}, 2.29 \mathrm{mmol})$ was added portionwise. The black reaction mixture was stirred for $30 \mathrm{~min}$ at $0{ }^{\circ} \mathrm{C}$, and the solvent was removed under reduced pressure.
The crude product was dissolved in ethyl acetate $(50 \mathrm{~mL})$ and treated with aqueous $\mathrm{NH}_{4} \mathrm{Cl}(2 \times 10 \mathrm{~mL})$. The organic layer was washed with brine and dried over anhydrous $\mathrm{Na}_{2} \mathrm{SO}_{4}$. The organic solvent was evaporated under reduced pressure and the product was chromatographed on silica gel, with ethyl acetate/hexanes as eluent, to afford the desired product 195 (473 mg, 94\%) as a white solid. ${ }^{1} \mathrm{H}$ NMR $\left(\right.$ DMSO- $\left.d_{6}, 600 \mathrm{MHz}\right) \delta 11.50(\mathrm{~s}, 1 \mathrm{H}), 7.97(\mathrm{t}, J=5.8 \mathrm{~Hz}, 1 \mathrm{H}), 7.24$ $(\mathrm{s}, 1 \mathrm{H}), 6.55(\mathrm{dd}, J=2.3,3.9 \mathrm{~Hz}, 1 \mathrm{H}), 5.86(\mathrm{dd}, J=2.6,5.4 \mathrm{~Hz}, 1 \mathrm{H})$, $5.72(\mathrm{~s}, 1 \mathrm{H}), 3.62(\mathrm{~d}, J=5.8 \mathrm{~Hz}, 2 \mathrm{H}), 2.75(\mathrm{t}, J=7.4 \mathrm{~Hz}, 2 \mathrm{H}), 2.41(\mathrm{t}$, $J=7.4 \mathrm{~Hz}, 2 \mathrm{H}), 2.00(\mathrm{br} \mathrm{s}, 3 \mathrm{H}), 1.91(\mathrm{~d}, J=2.6 \mathrm{~Hz}, 6 \mathrm{H}), 1.60(\mathrm{br} \mathrm{s}$, $6 \mathrm{H}) ;{ }^{13} \mathrm{C}$ NMR (DMSO- $\left.d_{6}, 100 \mathrm{MHz}\right) \delta 171.8,167.9,130.8,116.0$, 107.0, 104.2, 50.7, 42.3, 41.0 (3C), 35.9 (3C), 35.3, 28.8 (3C), 23.2; HRMS (ESI) calcd for $\mathrm{C}_{19} \mathrm{H}_{28} \mathrm{~N}_{3} \mathrm{O}_{2}(\mathrm{M}+\mathrm{H})^{+}$330.2176, found 330.2169

Synthesis of $N^{1}$-(3-(Pyrrol-2-yl)propyl)- $N^{2}$-(adamantan-1-yl)ethane-1,2-diamine (196). Compound 196 (178 mg, 78\%) was synthesized by the same procedure as described for $67 \mathrm{a} .{ }^{1} \mathrm{H}$ NMR $\left(\mathrm{CDCl}_{3}, 400 \mathrm{MHz}\right) \delta 9.28(\mathrm{br} \mathrm{s}, 1 \mathrm{H}), 6.68(\mathrm{~s}, 1 \mathrm{H}), 6.12(\mathrm{t}, J=2.8 \mathrm{~Hz}$, $1 \mathrm{H}), 5.92(\mathrm{~m}, 1 \mathrm{H}), 2.78-2.66(\mathrm{~m}, 8 \mathrm{H}), 2.16(\mathrm{br} \mathrm{s}, 2 \mathrm{H}), 2.09$ (br s, $3 \mathrm{H}), 1.83(\mathrm{~m}, 2 \mathrm{H}), 1.86-1.67(\mathrm{~m}, 12 \mathrm{H}) ;{ }^{13} \mathrm{C} \mathrm{NMR}\left(\mathrm{CDCl}_{3}, 100\right.$ $\mathrm{MHz}) \delta 132.1,116.2,107.9,104.9,50.1,50.0,48.9,42.6$ (3C), 39.6, 36.7 (3C), 29.6 (4C), 25.6; HRMS (ESI) calcd for $\mathrm{C}_{19} \mathrm{H}_{32} \mathrm{~N}_{3}(\mathrm{M}+\mathrm{H})^{+}$ 302.2591, found 302.2587.

In Vitro Antimalarial Activity: P. falciparum Growth Inhibition. In vitro antimalarial activity was determined by the malaria SYBR Green I-based fluorescence (MSF) assay described previously ${ }^{66}$ with minor modifications as previously described, ${ }^{67}$ and expressed as the compound concentration inhibiting growth by $50 \%\left(\mathrm{IC}_{50}\right)$.

HepG2 Cytotoxicity Assay. Drugs were dissolved in DMSO to make $10 \mathrm{mM}$ stock solutions. Human hepatocarcinoma cells (HepG2) were maintained on RPMI-1640 medium supplemented with $10 \%$ fetal bovine serum at $37{ }^{\circ} \mathrm{C}$ in a humidified $5 \% \mathrm{CO}_{2}$ atmosphere. Cells were seeded at a density of $2 \times 10^{4}$ per well in 96-well flat-bottom tissue culture plates containing complete medium in a total volume of $160 \mu \mathrm{L} /$ well. The cells were allowed to attach at $37^{\circ} \mathrm{C}$ overnight. On the following day, drug solutions ( $40 \mu \mathrm{L} /$ well) were serially diluted with complete culture medium across the plate. The plates were then incubated at $37{ }^{\circ} \mathrm{C}$ and $5 \% \mathrm{CO}_{2}$ for another $24-36 \mathrm{~h}$. Afterward, the medium was aspirated and replaced with complete RPMI medium (200 $\mu \mathrm{L} /$ well), and the plates were incubated for an additional $24 \mathrm{~h}$ at $37^{\circ} \mathrm{C}$ and $5 \% \mathrm{CO}_{2}$. An aliquot of a stock solution of resazurin (Alamar Blue, prepared in $1 \times$ PBS) was then added at $20 \mu \mathrm{L}$ per well (final concentration $10 \mu \mathrm{M}$ ), and the plates were returned to the incubator for $3 \mathrm{~h}$. After this period, fluorescence in each well, indicative of cellular redox activity, was measured in a Gemini EM plate reader with excitation wavelength at $560 \mathrm{~nm}$ and emission wavelength at $590 \mathrm{~nm}^{68,69} \mathrm{IC}_{50}$ values were determined by nonlinear regression analysis of logistic concentration-fluorescence intensity curves (GraphPad Prism software).

In Vivo Efficacy against Murine Malaria. The in vivo activity of selected PGs and TAs was assessed against the blood stages using a modified 4-day test. ${ }^{71,72}$ The 4- to 5-week-old female CF1 mice (Charles River Laboratories) were infected intravenously with $2.5 \times$ $10^{5}$ P. yoelii (Kenya strain, MR4 MRA-428) parasitized erythrocytes from a donor animal. Drug administration commenced the day after the animals were inoculated (day 1). The test compounds were dissolved in PEG-400 and administered by oral gavage once daily for 4 successive days; chloroquine phosphate was used as a positive control. Blood for blood film analysis and body weights were obtained on the day following the last dose and then at weekly intervals through day 28. Blood films were Giemsa stained and examined microscopically to determine the levels of parasitemia. These blood samples were collected from the tail vein with the aid of a syringe needle. All mice were observed daily to assess their clinical signs, which were recorded. Animals with observable parasitemia following the experiment were euthanized; animals cleared of parasites from their bloodstream were observed daily with assessment of parasitemia performed weekly until day 28 , at which point we score the animal(s) as cured of infection, and the animals were euthanized. All treated mice with a negative smear on day 28 were considered cured (100\% protection). $\mathrm{ED}_{50}$ values $\left(\mathrm{mg} \mathrm{kg}^{-1}\right.$ day $\left.^{-1}\right)$ 
were derived graphically from the dose required to reduce parasite burden by $50 \%$ relative to drug-free controls.

\section{ASSOCIATED CONTENT}

\section{S Supporting Information}

The Supporting Information is available free of charge on the ACS Publications website at DOI: 10.1021/acs.jmedchem.5b00560.

Molecular formula strings (XLSX)

Structural characterization data and spectra (NMR, and HRMS) of all final compounds (PDF)

\section{AUTHOR INFORMATION}

\section{Corresponding Author}

*E-mail: reynoldk@pdx.edu. Phone: 503725 3886. Fax: 503 725 5800. Mailing address: Finance \& Administration, Portland State University, P.O. Box 751, Portland, Oregon, 97207-0751.

\section{Notes}

United States provisional patent application has been filed by the Portland State University to protect the intellectual property described in this report.

The authors declare no competing financial interest.

\section{ACKNOWLEDGMENTS}

This work was supported by a grant from the National Institutes of Health (Grant GM077147).

\section{ABBREVIATIONS USED}

$\mathrm{CQ}^{\mathrm{R}} P f$, chloroquine-resistant $P$. falciparum; $\mathrm{CQ}^{\mathrm{R}}$, chloroquineresistant; $\mathrm{CQ}^{\mathrm{S}}$, chloroquine-sensitive; $P f$, Plasmodium falciparum; PG, prodiginine; TA, tambjamine; PPM, pyrrolylpyrromethene; SAR, structure-activity relationship; $C Q$ chloroquine; $M Q$, mefloquine; $\mathrm{IC}_{50}$, half maximal inhibitory concentration; $\mathrm{nM}$, nanomolar; MDR, multidrug-resistant; ADMET, adsorption, distribution, metabolism, excretion, and toxicity; $\mathrm{ED}_{50}$, median effective dose; NRD, nonrecrudescence dose (the amount of drug needed for $100 \%$ protection to malaria-infected mice until day 28)

\section{REFERENCES}

(1) WHO. World Malaria Report 2014. http://www.who.int/ malaria/publications/world_malaria_report_2014/en/.

(2) Hyde, J. E. Drug-resistant malaria. Trends Parasitol. 2005, 21, 494-498.

(3) Dondorp, A. M.; Nosten, F.; Yi, P.; Das, D.; Phyo, A. P.; Tarning, J.; Lwin, K. M.; Ariey, F.; Hanpithakpong, W.; Lee, S. J.; Ringwald, P.; Silamut, K.; Imwong, M.; Chotivanich, K.; Lim, P.; Herdman, T.; An, S. S.; Yeung, S.; Singhasivanon, P.; Day, N. P.; Lindegardh, N.; Socheat, D.; White, N. J. Artemisinin resistance in Plasmodium falciparum malaria. N. Engl. J. Med. 2009, 361, 455-467.

(4) Manderville, R. A. Synthesis, proton-affinity and anti-cancer properties of the prodigiosin-group natural products. Curr. Med. Chem.: Anti-Cancer Agents 2001, 1, 195-218.

(5) Fürstner, A. Chemistry and biology of roseophilin and the prodigiosin alkaloids: a survey of the last 2500 years. Angew. Chem., Int. Ed. 2003, 42, 3582-3603.

(6) Boonlarppradab, C.; Kauffman, C. A.; Jensen, P. R.; Fenical, W. Marineosins $\mathrm{A}$ and $\mathrm{B}$, cytotoxic spiroaminals from a marine-derived actinomycete. Org. Lett. 2008, 10, 5505-5508.

(7) Salem, S. M.; Kancharla, P.; Florova, G.; Gupta, S.; Lu, W.; Reynolds, K. A. Elucidation of final steps of the marineosins biosynthetic pathway through identification and characterization of the corresponding gene cluster. J. Am. Chem. Soc. 2014, 136, 45654574.
(8) Haynes, S. W.; Sydor, P. K.; Stanley, A. E.; Song, L.; Challis, G. L. Role and substrate specificity of the Streptomyces coelicolor RedH enzyme in undecylprodiginine biosynthesis. Chem. Commun. 2008, $1865-1867$.

(9) Sydor, P. K.; Barry, S. M.; Odulate, O. M.; Barona-Gomez, F.; Haynes, S. W.; Corre, C.; Song, L.; Challis, G. L. Regio- and stereodivergent antibiotic oxidative carbocyclizations catalysed by Rieske oxygenase-like enzymes. Nat. Chem. 2011, 3, 388-392.

(10) Burke, C.; Thomas, T.; Egan, S.; Kjelleberg, S. The use of functional genomics for the identification of a gene cluster encoding for the biosynthesis of an antifungal tambjamine in the marine bacterium Pseudoalteromonas tunicate. Environ. Microbiol. 2007, 9, 814-818.

(11) Kojiri, K.; Nakajima, S.; Suzuki, H.; Okura, A.; Suda, H. A new antitumor substance, BE-18591, produced by a streptomycete. I. Fermentation, isolation, physico-chemical and biological properties. $J$. Antibiot. 1993, 46, 1799-1803.

(12) Boger, D. L.; Patel, M. J. Total synthesis of prodigiosin, prodigiosene, and desmethoxyprodigiosin: Diels-Alder reactions of heterocyclic azadienes and development of an effective palladium(II)promoted 2,2'-bipyrrole coupling procedure. J. Org. Chem. 1988, 53, $1405-1415$.

(13) Alihosseini, F.; Ju, K. S.; Lango, J.; Hammock, B. D.; Sun, G. Antibacterial colorants: characterization of prodiginines and their applications on textile materials. Biotechnol. Prog. 2008, 24, 742-747.

(14) Marchal, E.; Uddin, M. I.; Smithen, D. A.; Hawco, C. L. A.; Lanteigne, M.; Overy, D. P.; Kerr, R. G.; Thompson, A. Antimicrobial activity of non-natural prodigiosenes. RSC Adv. 2013, 3, 2296722971.

(15) Nakamura, A.; Nagai, K.; Ando, K.; Tamura, G. Selective suppression by prodigiosin of the mitogenic response of murine splenocytes. J. Antibiot. 1986, 39, 1155-1159.

(16) Tsuji, R. F.; Yamamoto, M.; Nakamura, A.; Kataoka, T.; Magae, J.; Nagai, K.; Yamasaki, M. Selective immunosuppression of prodigiosin 25-C and FK 506 in the murine immune system. J. Antibiot. 1990, 43, 1293-1301.

(17) Stepkowski, S. M.; Erwin-Cohen, R. A.; Behbod, F.; Wang, M.E.; Qu, X.; Tejpal, N.; Nagy, Z. S.; Kahan, B. D.; Kirken, R. A. Selective inhibitor of Janus tyrosine kinase 3, PNU156804, prolongs allograft survival and acts synergistically with cyclosporine but additively with rapamycin. Blood 2002, 99, 680-689.

(18) Stepkowski, S. M.; Nagy, Z. S.; Wang, M.-E.; Behbod, F.; ErwinCohen, R.; Kahan, B. D.; Kirken, R. A. The role of stat5 in the induction of regulatory $\mathrm{T}$ cells in transplantation tolerance. Transplant. Proc. 2001, 33, 3835-3836.

(19) Magae, J.; Miller, J. W.; Nagai, K.; Shearer, G. M. Effect of metacycloprodigiosin, an inhibitor of killer $\mathrm{T}$ cells, on murine skin and heart transplants. J. Antibiot. 1996, 49, 86-90.

(20) D'Alessio, R.; Bargiotti, A.; Carlini, O.; Colotta, F.; Ferrari, M.; Gnocchi, P.; Isetta, A.; Mongelli, N.; Motta, P.; Rossi, A.; Rossi, M.; Tibolla, M.; Vanotti, E. Synthesis and immunosuppressive activity of novel prodigiosin derivatives. J. Med. Chem. 2000, 43, 2557-2565.

(21) Tanigaki, K.; Sato, T.; Tanaka, Y.; Ochi, T.; Nishikawa, A.; Nagai, K.; Kawashima, H.; Ohkuma, S. BE-18591 as a new $\mathrm{H}^{+} / \mathrm{Cl}^{-}$ symport ionophore that inhibits immunoproliferation and gastritis. FEBS Lett. 2002, 524, 37-42.

(22) Han, S. B.; Kim, H. M.; Kim, Y. H.; Lee, C. W.; Jang, E. S.; Son, K. H.; Kim, S. U.; Kim, Y. K. T-cell specific immunosuppression by prodigiosin isolated from Serratia marcescens. Int. J. Immunopharmacol. 1998, 20, 1-13.

(23) Williams, R. P.; Hearn, W. R. Prodigiosin. Antibiotics 1967, 2, 410-432.

(24) Regourd, J.; Al-Sheikh Ali, A.; Thompson, A. Synthesis and anticancer activity of C-ring-functionalized prodigiosin analogues. $J$. Med. Chem. 2007, 50, 1528-1536.

(25) Aldrich, L. N.; Stoops, S. L.; Crews, B. C.; Marnett, L. J.; Lindsley, C. W. Total synthesis and biological evaluation of tambjamine $\mathrm{K}$ and a library of unnatural analogs. Bioorg. Med. Chem. Lett. 2010, 20, 5207-5211. 
(26) Smithen, D. A.; Forrester, A. M.; Corkery, D. P.; Dellaire, G.; Colpitts, J.; McFarland, S. A.; Berman, J. N.; Thompson, A. Investigations regarding the utility of prodigiosenes to treat leukemia. Org. Biomol. Chem. 2013, 11, 62-68.

(27) Hawco, C. L. A.; Marchal, E.; Uddin, M. I.; Baker, A. E. G.; Corkery, D. P.; Dellaire, G.; Thompson, A. Synthesis and biological evaluation of prodigiosene conjugates of porphyrin, estrone and 4hydroxytamoxifen. Bioorg. Med. Chem. 2013, 21, 5995-6002.

(28) Sessler, J. L.; Eller, L. R.; Cho, W.-S.; Nicolaou, S.; Aguilar, A.; Lee, J. T.; Lynch, V. M.; Magda, D. J. Synthesis, anion-binding properties, and in vitro anticancer activity of prodigiosin analogues. Angew. Chem., Int. Ed. 2005, 44, 5989-5992.

(29) Díaz de Greñu, B.; Hernández, P. I.; Espona, M.; Quiñonero, D.; Light, M. E.; Torroba, T.; Pérez-Tomás, R.; Quesada, R. Synthetic prodiginine obatoclax (GX15-070) and related analogues: anion binding, transmembrane transport, and cytotoxicity properties. Chem. - Eur. J. 2011, 17, 14074-14083.

(30) Marchal, E.; Rastogi, S.; Thompson, A.; Davis, J. T. Influence of B-ring modifications on proton affinity, transmembrane anion transport and anti-cancer properties of synthetic prodigiosenes. Org. Biomol. Chem. 2014, 12, 7515-7522.

(31) Castro, A. J. Antimalarial activity of prodigiosin. Nature 1967, 213, 903-904.

(32) Gerber, N. N. A new prodiginine (prodigiosin-like) pigment from streptomyces. Antimalarial activity of several prodiginines. J. Antibiot. 1975, 28, 194-199.

(33) Davidson, D. E., Jr.; Johnsen, D. O.; Tanticharoenyos, P.; Hickman, R. L.; Kinnamon, K. E. Evaluating new antimalarial drugs against trophozoite induced Plasmodium cynomolgi malaria in rhesus monkeys. Am. J. Trop. Med. Hyg. 1976, 25, 26-33.

(34) Isaka, M.; Jaturapat, A.; Kramyu, J.; Tanticharoen, M.; Thebtaranonth, Y. Potent in vitro antimalarial activity of metacycloprodigiosin isolated from Streptomyces spectabilis BCC 4785. Antimicrob. Agents Chemother. 2002, 46, 1112-1113.

(35) Lazaro, J. E. H.; Nitcheu, J.; Predicala, R. Z.; Mangalindan, G. C.; Nesslany, F.; Marzin, D.; Concepcion, G. P.; Diquet, B. Heptyl prodigiosin, a bacterial metabolite, is antimalarial in vivo and nonmutagenic in vitro. J. Nat. Toxins 2002, 11, 367-377.

(36) Marchal, E.; Smithen, D. A.; Uddin, M. I.; Robertson, A. W.; Jakeman, D. L.; Mollard, V.; Goodman, C. D.; MacDougall, K. S.; McFarland, S. A.; McFadden, G. I.; Thompson, A. Synthesis and antimalarial activity of prodigiosenes. Org. Biomol. Chem. 2014, 12, 4132-4142.

(37) Papireddy, K.; Smilkstein, M.; Kelly, J. X.; Shweta; Salem, S. M.; Alhamadsheh, M.; Haynes, S. W.; Challis, G. L.; Reynolds, K. A. Antimalarial activity of natural and synthetic prodiginines. J. Med. Chem. 2011, 54, 5296-5306.

(38) Kancharla, P.; Lu, W.; Salem, S. M.; Kelly, J. X.; Reynolds, K. A. Stereospecific synthesis of 23-hydroxyundecylprodiginines and analogues, and conversion to antimalarial premarineosins via a novel Rieske oxygenase catalyzed bicyclization. J. Org. Chem. 2014, 79, 11674-11689.

(39) Saez Dias, R. I.; Regourd, J.; Santacroce, P. V.; Davis, J. T.; Jakeman, D. L.; Thompson, A. Chloride anion transport and coppermediated DNA cleavage by $\mathrm{C}$-ring functionalized prodigiosenes. Chem. Commun. 2007, 2701-2703.

(40) Seganish, J. L.; Davis, J. T. Prodigiosin is a chloride carrier that can function as an anion exchanger. Chem. Commun. 2005, 57815783.

(41) Melvin, M. S.; Tomlinson, J. T.; Park, G.; Day, C. S.; Saluta, G. S.; Kucera, G. L.; Manderville, R. A. Influence of the A-ring on the proton affinity and anticancer properties of the prodigiosins. Chem. Res. Toxicol. 2002, 15, 734-741.

(42) Ohkuma, S.; Sato, T.; Okamoto, M.; Matsuya, H.; Arai, K.; Kataoka, T.; Nagai, K.; Wasserman, H. H. Prodigiosins uncouple lysosomal vacuolar-type ATPase through promotion of $\mathrm{H}^{+} / \mathrm{Cl}^{-}$ symport. Biochem. J. 1998, 334, 731-741.
(43) Gale, P. A.; Light, M. E.; McNally, B.; Navakhun, K.; Sliwinski, K. E.; Smith, B. D. Co-transport of $\mathrm{H}^{+} / \mathrm{Cl}^{-}$by a synthetic prodigiosin mimic. Chem. Commun. 2005, 3773-3775.

(44) Davis, J. T.; Gale, P. A.; Okunola, O. A.; Prados, P.; IglesiasSanchez, J. C.; Torroba, T.; Quesada, R. Using small molecules to facilitate exchange of bicarbonate and chloride anions across liposomal membranes. Nat. Chem. 2009, 1, 138-144.

(45) Rastogi, S.; Marchal, E.; Uddin, I.; Groves, B.; Colpitts, J.; McFarland, S. A.; Davis, J.T.; Thompson, A. Synthetic prodigiosenes and the influence of C-ring substitution on DNA cleavage, transmembrane chloride transport and basicity. Org. Biomol. Chem. 2013, 11, 3834-3845.

(46) Melvin, M. S.; Ferguson, D. C.; Lindquist, N.; Manderville, R. A. DNA Binding by 4-methoxypyrrolic natural products. Preference for intercalation at AT sites by tambjamine $\mathrm{E}$ and prodigiosin. J. Org. Chem. 1999, 64, 6861-6869.

(47) Cavalcanti, B. C.; Júnior, H. V. N.; Seleghim, M. H. R.; Berlinck, R. G. S.; Cunha, G. M. A.; Moraes, M. O.; Pessoa, C. Cytotoxic and genotoxic effects of tambjamine $\mathrm{D}$, an alkaloid isolated from the nudibranch Tambja eliora, on Chinese hamster lung fibroblasts. Chem.Biol. Interact. 2008, 174, 155-162.

(48) Melvin, M. S.; Tomlinson, J. T.; Saluta, G. R.; Kucera, G. L.; Lindquist, N.; Manderville, R. A. Double-strand DNA cleavage by copper-prodigiosin. J. Am. Chem. Soc. 2000, 122, 6333-6334.

(49) Borthakur, G.; O’Brien, S.; Ravandi-Kashani, F.; Giles, F.; Schimmer, A. D.; Viallet, J.; Kantarjian, H. A Phase I trial of the small molecule Pan-Bcl-2 family inhibitor obatoclax mesylate (GX15-070) administered by 24 hour infusion every 2 weeks to patients with myeloid malignancies and chronic lymphocytic leukemia (CLL). Blood (ASH Annu. Meet. Abstr.) 2006, 108, 2654.

(50) Nguyen, M.; Marcellus, R. C.; Roulston, A.; Watson, M.; Serfass, L.; Madiraju, S. R. M.; Goulet, D.; Viallet, J.; Bélec, L.; Billot, X.; Acoca, S.; Purisima, E.; Wiegmans, A.; Cluse, L.; Johnstone, R. W.; Beauparlant, P.; Shore, G. C. Small molecule obatoclax (GX15-070) antagonizes MCL-1 and overcomes MCL-1-mediated resistance to apoptosis. Proc. Natl. Acad. Sci. U. S. A. 2007, 104, 19512-19517.

(51) Chen, K.; Rannulu, N. S.; Cai, Y.; Lane, P.; Liebl, A. L.; Rees, B. B.; Corre, C.; Challis, G. L.; Cole, R. B. Unusual odd-electron fragments from even-electron protonated prodiginine precursors using positive-ion electrospray tandem mass spectrometry. J. Am. Soc. Mass Spectrom. 2008, 19, 1856-1866.

(52) Wasserman, H. H.; Rodgers, G. C.; Keith, D. D. Metacycloprodigiosin, a tripyrrole pigment from Streptomyces longisporus ruber. J. Am. Chem. Soc. 1969, 91, 1263-1264.

(53) Kancharla, P.; Reynolds, K. A. Synthesis of 2,2'-bipyrrole-5carboxaldehydes and their application in the synthesis of B-ring functionalized prodiginines and tambjamines. Tetrahedron 2013, 69, 8375-8385.

(54) Dairi, K.; Tripathy, S.; Attardo, G.; Lavallee, J.-F. Two-step synthesis of the bipyrrole precursor of prodigiosins. Tetrahedron Lett. 2006, 47, 2605-2606.

(55) Li, W.-R.; Lin, S. T.; Hsu, N.-M.; Chern, M.-S. Efficient total synthesis of pulchellalactam, a CD45 protein tyrosine phosphatase inhibitor. J. Org. Chem. 2002, 67, 4702-4706.

(56) Yoon-Miller, S. J. P.; Opalka, S. M.; Pelkey, E. T. Short synthesis of 4-aryl-3-pyrrolin-2-ones. Tetrahedron Lett. 2007, 48, 827-830.

(57) Leen, V.; Braeken, E.; Luckermans, K.; Jackers, C.; Van der Auweraer, M.; Boens, N.; Dehaen, W. A versatile, modular synthesis of monofunctionalized BODIPY dyes. Chem. Commun. 2009, 45154517.

(58) Roth, S. D.; Shkindel, T.; Lightner, D. A. Intermolecularly hydrogen-bonded dimeric helices: tripyrrindiones. Tetrahedron 2007, 63, 11030-11039.

(59) Ono, N.; Kawamura, H.; Bougauchi, M.; Maruyama, K. Intermolecularly hydrogen-bonded dimeric helices: tripyrrindiones. Tetrahedron 1990, 46, 7483-7496.

(60) Yadav, J. S.; Reddy, B. V. S.; Kondaji, G.; Rao, R. S.; Kumar, S. P. Zinc-mediated acylation and sulfonation of pyrrole and its derivative. Tetrahedron Lett. 2002, 43, 8133-8135. 
(61) He, Y.; Lin, M.; Li, Z.; Liang, X.; Li, G.; Antilla, J. C. Direct synthesis of chiral 1,2,3,4-tetrahydropyrrolo[1,2-a]pyrazines via a catalytic asymmetric intramolecular aza-Friedel-Crafts reaction. Org. Lett. 2011, 13, 4490-4493.

(62) Fürstner, A.; Grabowski, J.; Lehmann, C. W. Total synthesis and structural refinement of the cyclic tripyrrole pigment nonylprodigiosin. J. Org. Chem. 1999, 64, 8275-8280.

(63) Schnölzer, M.; Alewood, P.; Jones, A.; Alewood, D.; Kent, S. B. $\mathrm{H}$. In situ neutralization in Boc-chemistry solid phase peptide synthesis. Int. J. Pept. Res. Ther. 2007, 13, 31-44.

(64) Wadsworth, W. Synthetic applications of phosphoryl-stabilized anions. Org. React. 1977, 25, 73-253.

(65) Wadsworth, W. S., Jr.; Emmons, W. D. Ethyl cyclohexylideneacetate. Org. Synth. 1965, 45, 44.

(66) Smilkstein, M. J.; Sriwilaijaroen, N.; Kelly, J. X.; Wilairat, P.; Riscoe, M. Simple and inexpensive fluorescence-based technique for high-throughput antimalarial drug screening. Antimicrob. Agents Chemother. 2004, 48, 1803-1806.

(67) Kelly, J. X.; Smilkstein, M. J.; Cooper, R. A.; Lane, K. D.; Johnson, R. A.; Janowsky, A.; Dodean, R. A.; Hinrichs, D. J.; Winter, R.; Riscoe, M. Design, synthesis, and evaluation of $10-\mathrm{N}$-substituted acridones as novel chemosensitizers in Plasmodium falciparum. Antimicrob. Agents Chemother. 2007, 51, 4133-4140.

(68) Zhi-Jun, Y.; Sriranganathan, N.; Vaught, T.; Arastu, S. K.; Ahmed, S. A. A dye-based lymphocyte proliferation assay that permits multiple immunological analyses: mRNA, cytogenetic, apoptosis, and immunophenotyping studies. J. Immunol. Methods 1997, 210, 25-39.

(69) Nilsen, A.; Miley, G. P.; Forquer, I. P.; Mather, M. W.; Katneni, K.; Li, Y.; Pou, S.; Pershing, A. M.; Stickles, A. M.; Ryan, E.; Kelly, J. X.; Doggett, J. S.; White, K. L.; Hinrichs, D. J.; Winter, R. W.; Charman, S. A.; Zakharov, L. N.; Bathurst, I.; Burrows, J. N.; Vaidya, A. B.; Riscoe, M. K. Discovery, synthesis, and optimization of antimalarial 4(1H)-quinolone-3-diarylethers. J. Med. Chem. 2014, 57, $3818-3834$.

(70) Gleeson, M. P. Generation of a set of simple, interpretable ADMET rules of thumb. J. Med. Chem. 2008, 51, 817-834.

(71) Peters, W.; Davies, E. E.; Robinson, B. L. The chemotherapy of rodent malaria, XXIII Causal prophylaxis, part II: Practical experience with Plasmodium yoelii nigeriensis in drug screening. Ann. Trop. Med. Parasitol. 1975, 69, 311-328.

(72) Ager, A. J. Rodent Malaria Models; Springer-Verlag: New York, 1984; Vol. 68, pp 225-264. 